


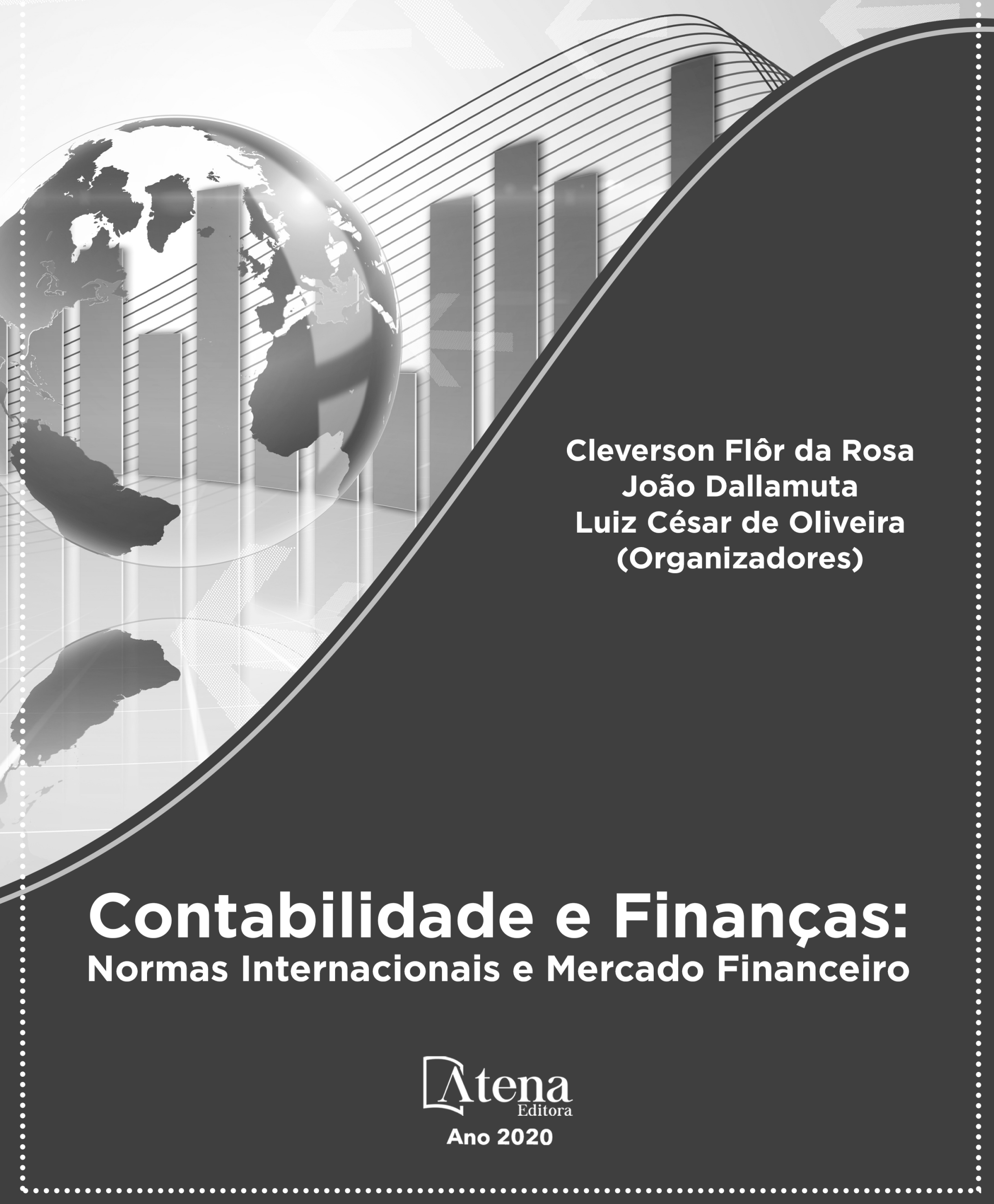



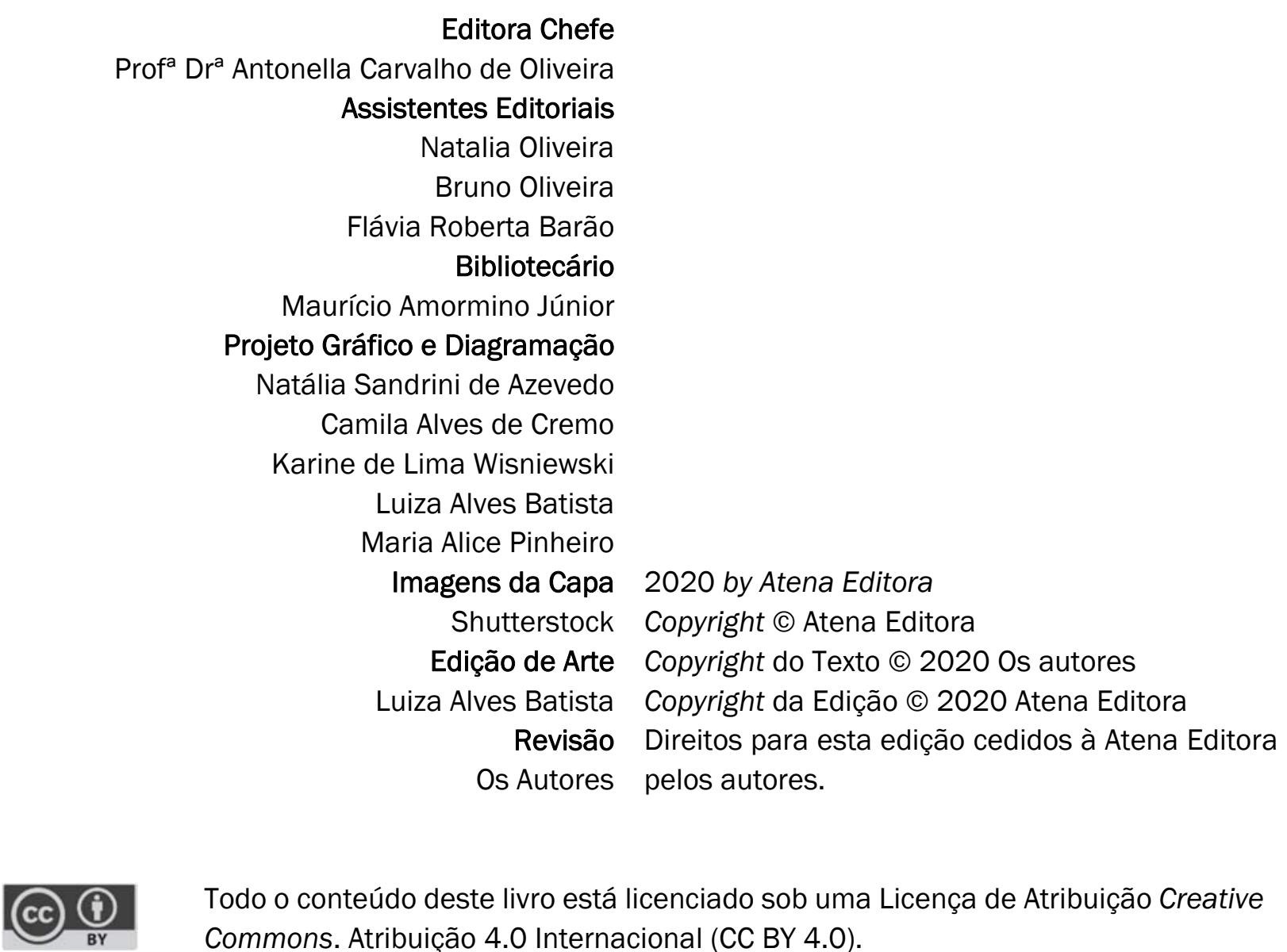

Todo o conteúdo deste livro está licenciado sob uma Licença de Atribuição Creative Commons. Atribuição 4.0 Internacional (CC BY 4.0).

O conteúdo dos artigos e seus dados em sua forma, correção e confiabilidade são de responsabilidade exclusiva dos autores, inclusive não representam necessariamente a posição oficial da Atena Editora. Permitido o download da obra e o compartilhamento desde que sejam atribuídos créditos aos autores, mas sem a possibilidade de alterá-la de nenhuma forma ou utilizá-la para fins comerciais.

A Atena Editora não se responsabiliza por eventuais mudanças ocorridas nos endereços convencionais ou eletrônicos citados nesta obra.

Todos os manuscritos foram previamente submetidos à avaliação cega pelos pares, membros do Conselho Editorial desta Editora, tendo sido aprovados para a publicação.

\section{Conselho Editorial}

Ciências Humanas e Sociais Aplicadas

Prof. Dr. Álvaro Augusto de Borba Barreto - Universidade Federal de Pelotas

Prof. Dr. Alexandre Jose Schumacher - Instituto Federal de Educação, Ciência e Tecnologia de Mato Grosso

Prof. Dr. Américo Junior Nunes da Silva - Universidade do Estado da Bahia

Prof. Dr. Antonio Carlos Frasson - Universidade Tecnológica Federal do Paraná

Prof. Dr. Antonio Gasparetto Júnior - Instituto Federal do Sudeste de Minas Gerais

Prof. Dr. Antonio Isidro-Filho - Universidade de Brasília

Prof. Dr. Carlos Antonio de Souza Moraes - Universidade Federal Fluminense

Prof $^{a}$ Dr $^{\mathrm{a}}$ Cristina Gaio - Universidade de Lisboa

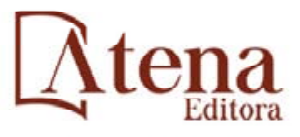


Prof. Dr. Deyvison de Lima Oliveira - Universidade Federal de Rondônia

Prof. Dr. Edvaldo Antunes de Farias - Universidade Estácio de Sá

Prof. Dr. Elson Ferreira Costa - Universidade do Estado do Pará

Prof. Dr. Eloi Martins Senhora - Universidade Federal de Roraima

Prof. Dr. Gustavo Henrique Cepolini Ferreira - Universidade Estadual de Montes Claros

Prof $^{a}$ Dr $^{a}$ Ivone Goulart Lopes - Istituto Internazionele delle Figlie de Maria Ausiliatrice

Prof. Dr. Jadson Correia de Oliveira - Universidade Católica do Salvador

Prof. Dr. Julio Candido de Meirelles Junior - Universidade Federal Fluminense

Prof $^{a}$ Dr $^{\mathrm{a}}$ Lina Maria Gonçalves - Universidade Federal do Tocantins

Prof. Dr. Luis Ricardo Fernandes da Costa - Universidade Estadual de Montes Claros

Prof $^{a}$ Dr $^{a}$ Natiéli Piovesan - Instituto Federal do Rio Grande do Norte

Prof. Dr. Marcelo Pereira da Silva - Pontifícia Universidade Católica de Campinas

Prof $^{a}$ Dr $^{a}$ Maria Luzia da Silva Santana - Universidade Federal de Mato Grosso do Sul

Prof $^{a}$ Dr $^{a}$ Paola Andressa Scortegagna - Universidade Estadual de Ponta Grossa

Prof $^{a}$ Dr $^{\mathrm{a}}$ Rita de Cássia da Silva Oliveira - Universidade Estadual de Ponta Grossa

Prof. Dr. Rui Maia Diamantino - Universidade Salvador

Prof. Dr. Urandi João Rodrigues Junior - Universidade Federal do Oeste do Pará

Prof $^{\mathrm{a}} \mathrm{Dr}^{\mathrm{a}}$ Vanessa Bordin Viera - Universidade Federal de Campina Grande

Prof. Dr. William Cleber Domingues Silva - Universidade Federal Rural do Rio de Janeiro

Prof. Dr. Willian Douglas Guilherme - Universidade Federal do Tocantins

\section{Ciências Agrárias e Multidisciplinar}

Prof. Dr. Alexandre Igor Azevedo Pereira - Instituto Federal Goiano

Prof $^{a}$ Dr $^{a}$ Carla Cristina Bauermann Brasil - Universidade Federal de Santa Maria

Prof. Dr. Antonio Pasqualetto - Pontifícia Universidade Católica de Goiás

Prof. Dr. Cleberton Correia Santos - Universidade Federal da Grande Dourados

Prof $^{a}$ Dr $^{a}$ Daiane Garabeli Trojan - Universidade Norte do Paraná

Prof $^{a}$ Dra $^{a}$ Diocléa Almeida Seabra Silva - Universidade Federal Rural da Amazônia

Prof. Dr. Écio Souza Diniz - Universidade Federal de Viçosa

Prof. Dr. Fábio Steiner - Universidade Estadual de Mato Grosso do Sul

Prof. Dr. Fágner Cavalcante Patrocínio dos Santos - Universidade Federal do Ceará

Prof $^{\mathrm{a}} \mathrm{Dr}^{\mathrm{a}}$ Girlene Santos de Souza - Universidade Federal do Recôncavo da Bahia

Prof. Dr. Jael Soares Batista - Universidade Federal Rural do Semi-Árido

Prof. Dr. Júlio César Ribeiro - Universidade Federal Rural do Rio de Janeiro

Prof $^{a}$ Dr $^{a}$ Lina Raquel Santos Araújo - Universidade Estadual do Ceará

Prof. Dr. Pedro Manuel Villa - Universidade Federal de Viçosa

Prof $^{a}{ }^{D} r^{a}$ Raissa Rachel Salustriano da Silva Matos - Universidade Federal do Maranhão

Prof. Dr. Ronilson Freitas de Souza - Universidade do Estado do Pará

Prof $^{a}$ Dr $^{a}$ Talita de Santos Matos - Universidade Federal Rural do Rio de Janeiro

Prof. Dr. Tiago da Silva Teófilo - Universidade Federal Rural do Semi-Árido

Prof. Dr. Valdemar Antonio Paffaro Junior - Universidade Federal de Alfenas

\section{Ciências Biológicas e da Saúde}

Prof. Dr. André Ribeiro da Silva - Universidade de Brasília

Prof $^{a}$ Dr $^{a}$ Anelise Levay Murari - Universidade Federal de Pelotas

Prof. Dr. Benedito Rodrigues da Silva Neto - Universidade Federal de Goiás

Prof. Dr. Douglas Siqueira de Almeida Chaves -Universidade Federal Rural do Rio de Janeiro

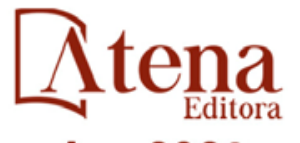


Prof. Dr. Edson da Silva - Universidade Federal dos Vales do Jequitinhonha e Mucuri

Prof $^{a}$ Dr $^{a}$ Eleuza Rodrigues Machado - Faculdade Anhanguera de Brasília

Prof $^{a}$ Dr $^{a}$ Elane Schwinden Prudêncio - Universidade Federal de Santa Catarina

Prof $^{a}$ Dr $^{a}$ Eysler Gonçalves Maia Brasil - Universidade da Integração Internacional da Lusofonia Afro-

Brasileira

Prof. Dr. Ferlando Lima Santos - Universidade Federal do Recôncavo da Bahia

Prof $^{a}$ Dr $^{\text {a }}$ Gabriela Vieira do Amaral - Universidade de Vassouras

Prof. Dr. Gianfábio Pimentel Franco - Universidade Federal de Santa Maria

Prof. Dr. Helio Franklin Rodrigues de Almeida - Universidade Federal de Rondônia

Prof $^{\mathrm{a}} \mathrm{Dr}^{\mathrm{a}}$ Iara Lúcia Tescarollo - Universidade São Francisco

Prof. Dr. Igor Luiz Vieira de Lima Santos - Universidade Federal de Campina Grande

Prof. Dr. Jesus Rodrigues Lemos - Universidade Federal do Piauí

Prof. Dr. Jônatas de França Barros - Universidade Federal do Rio Grande do Norte

Prof. Dr. José Max Barbosa de Oliveira Junior - Universidade Federal do Oeste do Pará

Prof. Dr. Luís Paulo Souza e Souza - Universidade Federal do Amazonas

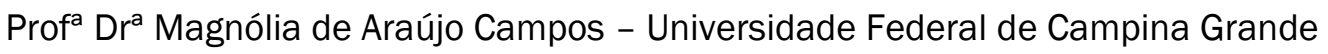

Prof. Dr. Marcus Fernando da Silva Praxedes - Universidade Federal do Recôncavo da Bahia

Prof $^{a} \mathrm{Dr}^{\mathrm{a}}$ Mylena Andréa Oliveira Torres - Universidade Ceuma

Prof $^{a}$ Dr $^{\text {a }}$ Natiéli Piovesan - Instituto Federacl do Rio Grande do Norte

Prof. Dr. Paulo Inada - Universidade Estadual de Maringá

Prof $^{\mathrm{a}} \mathrm{Dr}^{\mathrm{a}}$ Regiane Luz Carvalho - Centro Universitário das Faculdades Associadas de Ensino

Prof $^{a}$ Dr $^{\mathrm{a}}$ Renata Mendes de Freitas - Universidade Federal de Juiz de Fora

Prof $^{a}$ Dr $^{a}$ Vanessa Lima Gonçalves - Universidade Estadual de Ponta Grossa

Prof $^{a}$ Dr $^{\mathrm{a}}$ Vanessa Bordin Viera - Universidade Federal de Campina Grande

\section{Ciências Exatas e da Terra e Engenharias}

Prof. Dr. Adélio Alcino Sampaio Castro Machado - Universidade do Porto

Prof. Dr. Alexandre Leite dos Santos Silva - Universidade Federal do Piauí

Prof. Dr. Carlos Eduardo Sanches de Andrade - Universidade Federal de Goiás

Prof $^{\mathrm{a}} \mathrm{Dr}^{\mathrm{a}}$ Carmen Lúcia Voigt - Universidade Norte do Paraná

Prof. Dr. Douglas Gonçalves da Silva - Universidade Estadual do Sudoeste da Bahia

Prof. Dr. Eloi Rufato Junior - Universidade Tecnológica Federal do Paraná

Prof. Dr. Fabrício Menezes Ramos - Instituto Federal do Pará

Profa Dra. Jéssica Verger Nardeli - Universidade Estadual Paulista Júlio de Mesquita Filho

Prof. Dr. Juliano Carlo Rufino de Freitas - Universidade Federal de Campina Grande

Prof $^{a}$ Dr $^{\mathrm{a}}$ Luciana do Nascimento Mendes - Instituto Federal de Educação, Ciência e Tecnologia do Rio

Grande do Norte

Prof. Dr. Marcelo Marques - Universidade Estadual de Maringá

Prof $^{\mathrm{a}} \mathrm{Dr}^{\mathrm{a}}$ Neiva Maria de Almeida - Universidade Federal da Paraíba

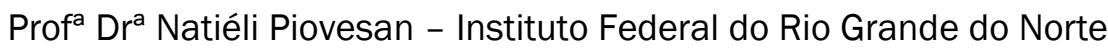

Prof. Dr. Takeshy Tachizawa - Faculdade de Campo Limpo Paulista

\section{Linguística, Letras e Artes}

Prof $^{a}$ Dr $^{a}$ Adriana Demite Stephani - Universidade Federal do Tocantins

Prof $^{a}$ Dra $^{\text {a }}$ Angeli Rose do Nascimento - Universidade Federal do Estado do Rio de Janeiro

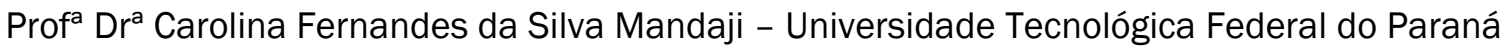

Prof $^{a} \operatorname{Dr}^{\mathrm{a}}$ Denise Rocha - Universidade Federal do Ceará

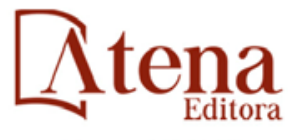


Prof. Dr. Fabiano Tadeu Grazioli - Universidade Regional Integrada do Alto Uruguai e das Missões

Prof. Dr. Gilmei Fleck - Universidade Estadual do Oeste do Paraná

Prof $^{a}$ Dr $^{a}$ Keyla Christina Almeida Portela - Instituto Federal de Educação, Ciência e Tecnologia de Mato Grosso

Prof $^{a}$ Dr $^{\mathrm{a}}$ Miranilde Oliveira Neves - Instituto de Educação, Ciência e Tecnologia do Pará

Prof $^{a}$ Dr $^{a}$ Sandra Regina Gardacho Pietrobon - Universidade Estadual do Centro-Oeste

Prof $^{a}$ Dr $^{\text {a }}$ Sheila Marta Carregosa Rocha - Universidade do Estado da Bahia

\section{Conselho Técnico Científico}

Prof. Me. Abrãao Carvalho Nogueira - Universidade Federal do Espírito Santo

Prof. Me. Adalberto Zorzo - Centro Estadual de Educação Tecnológica Paula Souza

Prof. Me. Adalto Moreira Braz - Universidade Federal de Goiás

Prof. Dr. Adaylson Wagner Sousa de Vasconcelos - Ordem dos Advogados do Brasil/Seccional Paraíba Prof. Dr. Adilson Tadeu Basquerote Silva - Universidade para o Desenvolvimento do Alto Vale do Itajaí Prof. Me. Alexsandro Teixeira Ribeiro - Centro Universitário Internacional

Prof. Me. André Flávio Gonçalves Silva - Universidade Federal do Maranhão

Prof $^{a}$ Ma. Anne Karynne da Silva Barbosa - Universidade Federal do Maranhão

Prof $^{a}$ Dr $^{\text {a }}$ Andreza Lopes - Instituto de Pesquisa e Desenvolvimento Acadêmico

Prof $^{a}$ Dr $^{\text {a }}$ Andrezza Miguel da Silva - Universidade Estadual do Sudoeste da Bahia

Prof. Dr. Antonio Hot Pereira de Faria - Polícia Militar de Minas Gerais

Prof. Me. Armando Dias Duarte - Universidade Federal de Pernambuco

Prof $^{a}$ Ma. Bianca Camargo Martins - UniCesumar

Prof $^{a}$ Ma. Carolina Shimomura Nanya - Universidade Federal de São Carlos

Prof. Me. Carlos Antônio dos Santos - Universidade Federal Rural do Rio de Janeiro

Prof. Ma. Cláudia de Araújo Marques - Faculdade de Música do Espírito Santo

Prof $^{a}$ Dr $^{a}$ Cláudia Taís Siqueira Cagliari - Centro Universitário Dinâmica das Cataratas

Prof. Me. Daniel da Silva Miranda - Universidade Federal do Pará

Profa Ma. Daniela da Silva Rodrigues - Universidade de Brasília

Profa Ma. Daniela Remião de Macedo - Universidade de Lisboa

Profa Ma. Dayane de Melo Barros - Universidade Federal de Pernambuco

Prof. Me. Douglas Santos Mezacas - Universidade Estadual de Goiás

Prof. Me. Edevaldo de Castro Monteiro - Embrapa Agrobiologia

Prof. Me. Eduardo Gomes de Oliveira - Faculdades Unificadas Doctum de Cataguases

Prof. Me. Eduardo Henrique Ferreira - Faculdade Pitágoras de Londrina

Prof. Dr. Edwaldo Costa - Marinha do Brasil

Prof. Me. Eliel Constantino da Silva - Universidade Estadual Paulista Júlio de Mesquita

Prof. Me. Ernane Rosa Martins - Instituto Federal de Educação, Ciência e Tecnologia de Goiás

Prof. Me. Euvaldo de Sousa Costa Junior - Prefeitura Municipal de São João do Piauí

Prof $^{a}$ Ma. Fabiana Coelho Couto Rocha Corrêa - Centro Universitário Estácio Juiz de Fora

Prof. Dr. Fabiano Lemos Pereira - Prefeitura Municipal de Macaé

Prof. Me. Felipe da Costa Negrão - Universidade Federal do Amazonas

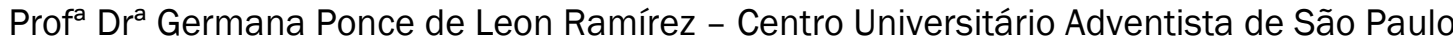

Prof. Me. Gevair Campos - Instituto Mineiro de Agropecuária

Prof. Dr. Guilherme Renato Gomes - Universidade Norte do Paraná

Prof. Me. Gustavo Krahl - Universidade do Oeste de Santa Catarina

Prof. Me. Helton Rangel Coutinho Junior - Tribunal de Justiça do Estado do Rio de Janeiro

Prof ${ }^{\mathrm{M}} \mathrm{M}$. Isabelle Cerqueira Sousa - Universidade de Fortaleza

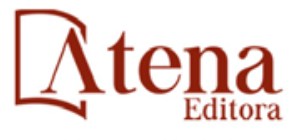


Prof $^{\mathrm{a}}$ Ma. Jaqueline Oliveira Rezende - Universidade Federal de Uberlândia

Prof. Me. Javier Antonio Albornoz - University of Miami and Miami Dade College

Prof. Me. Jhonatan da Silva Lima - Universidade Federal do Pará

Prof. Dr. José Carlos da Silva Mendes - Instituto de Psicologia Cognitiva, Desenvolvimento Humano e Social

Prof. Me. Jose Elyton Batista dos Santos - Universidade Federal de Sergipe

Prof. Me. José Luiz Leonardo de Araujo Pimenta - Instituto Nacional de Investigación Agropecuaria Uruguay

Prof. Me. José Messias Ribeiro Júnior - Instituto Federal de Educação Tecnológica de Pernambuco

Prof $^{a}$ Dr $^{\mathrm{a}}$ Juliana Santana de Curcio - Universidade Federal de Goiás

Prof $^{a}$ Ma. Juliana Thaisa Rodrigues Pacheco - Universidade Estadual de Ponta Grossa

Prof $^{a}$ Dr $^{a}$ Kamilly Souza do Vale - Núcleo de Pesquisas Fenomenológicas/UFPA

Prof. Dr. Kárpio Márcio de Siqueira - Universidade do Estado da Bahia

Prof $^{a}$ Dr $^{a}$ Karina de Araújo Dias - Prefeitura Municipal de Florianópolis

Prof. Dr. Lázaro Castro Silva Nascimento - Laboratório de Fenomenologia \& Subjetividade/UFPR

Prof. Me. Leonardo Tullio - Universidade Estadual de Ponta Grossa

Prof $^{\mathrm{a}}$ Ma. Lilian Coelho de Freitas - Instituto Federal do Pará

Prof $^{a}$ Ma. Liliani Aparecida Sereno Fontes de Medeiros - Consórcio CEDERJ

Prof $^{a}$ Dr $^{\mathrm{a}}$ Lívia do Carmo Silva - Universidade Federal de Goiás

Prof. Me. Lucio Marques Vieira Souza - Secretaria de Estado da Educação, do Esporte e da Cultura de Sergipe

Prof. Me. Luis Henrique Almeida Castro - Universidade Federal da Grande Dourados

Prof. Dr. Luan Vinicius Bernardelli - Universidade Estadual do Paraná

Prof. Dr. Michel da Costa - Universidade Metropolitana de Santos

Prof. Dr. Marcelo Máximo Purificação - Fundação Integrada Municipal de Ensino Superior

Prof. Me. Marcos Aurelio Alves e Silva - Instituto Federal de Educação, Ciência e Tecnologia de São Paulo

Profa Ma. Maria Elanny Damasceno Silva - Universidade Federal do Ceará

Prof $^{a}$ Ma. Marileila Marques Toledo - Universidade Federal dos Vales do Jequitinhonha e Mucuri

Prof. Me. Ricardo Sérgio da Silva - Universidade Federal de Pernambuco

Prof. Me. Rafael Henrique Silva - Hospital Universitário da Universidade Federal da Grande Dourados

Prof ${ }^{a}$ Ma. Renata Luciane Polsaque Young Blood - UniSecal

Prof. Me. Sebastião André Barbosa Junior - Universidade Federal Rural de Pernambuco

Prof $^{a}$ Ma. Silene Ribeiro Miranda Barbosa - Consultoria Brasileira de Ensino, Pesquisa e Extensão

Prof $^{a}$ Ma. Solange Aparecida de Souza Monteiro - Instituto Federal de São Paulo

Prof. Me. Tallys Newton Fernandes de Matos - Faculdade Regional Jaguaribana

Prof $^{a}$ Ma. Thatianny Jasmine Castro Martins de Carvalho - Universidade Federal do Piauí

Prof. Me. Tiago Silvio Dedoné - Colégio ECEL Positivo

Prof. Dr. Welleson Feitosa Gazel - Universidade Paulista 


\title{
Contabilidade e finanças: normas internacionais e mercado financeiro
}

\author{
Editora Chefe: Prof $^{\mathrm{a}} \mathrm{Dr}^{\mathrm{a}}$ Antonella Carvalho de Oliveira \\ Bibliotecário Maurício Amormino Júnior \\ Diagramação: Karine de Lima \\ Edição de Arte: Luiza Batista \\ Revisão: Os Autores \\ Organizadores: Cleverson Flôr da Rosa \\ João Dallamuta \\ Luiz César de Oliveira
}

\begin{tabular}{|c|c|}
\hline & $\begin{array}{c}\text { Dados Internacionais de Catalogação na Publicação (CIP) } \\
\text { (eDOC BRASIL, Belo Horizonte/MG) }\end{array}$ \\
\hline C759 & $\begin{array}{l}\text { Contabilidade e finanças [recurso eletrônico] : normas internacionais e } \\
\text { mercado financeiro / Organizadores Cleverson Flôr da Rosa, João } \\
\text { Dallamuta, Luiz César de Oliveira. - Ponta Grossa, PR: Atena, } \\
2020 \text {. }\end{array}$ \\
\hline & Formato: PDF \\
\hline & Requisitos de sistema: Adobe Acrobat Reader \\
\hline & Modo de acesso: World Wide Web \\
\hline & Inclui bibliografia \\
\hline & ISBN 978-65-5706-250-0 \\
\hline & DOI 10.22533/at.ed.500200308 \\
\hline & 1. Finanças. 2. Contabilidade. 3. Mercado financeiro. I. Rosa, \\
\hline & $\begin{array}{r}\text { Cleverson Flôr da. II. Dallamuta, João. III. Oliveira, Luiz César de. } \\
\text { CDD } 657\end{array}$ \\
\hline & Elaborado por Maurício Amormino Júnior - CRB6/2422 \\
\hline
\end{tabular}

Atena Editora

Ponta Grossa - Paraná - Brasil Telefone: +55 (42) 3323-5493 www.atenaeditora.com.br contato@atenaeditora.com.br 


\section{APRESENTAÇÃO}

A modernização tecnológica, agilidade de processos, foco em cliente, são alguns dos focos da gestão empresarial nas últimas décadas. Todas as organizações, independente do seu porte experimentaram ou ainda experimentam esforços visando estes objetivos.

A função financeira das empresas precisaram se adaptar a estes esforços. Mas sendo elas de uma natureza eminentemente de retaguarda, a sua transformação foi pouco visível, mesmo dentro das organizações.

Esta obra trás cinco pesquisas desenvolvidas por alunos e professores de três países (Brasil, Paraguai e Portugal) que tratam de temas relevantes para gestores financeiros nas áreas de contabilidade, avaliação de ativos e estruturação de sistemas / financeiros em empresas de serviço.

Aos autores e editores, nosso agradecimento pela oportunidade de organização da obra, críticas e sugestões são sempre bem-vindas.

Boa leitura

Cleverson Flor da Rosa

João Dallamuta

Luiz César de Oliveira 


\section{SUMÁRIO}

CAPÍTULO 1

ANÁLISE BIBLIOMÉTRICA

Caio Augusto Franco Lucas

Everton Ferreira Rossi

Josimar Pires da Silva

Katia Katsumi Arakaki

DOI 10.22533/at.ed.5002003081

CAPÍTULO 2

9

O IMPACTO DA ADOÇÃO DAS IFRS NA RELEVÂNCIA DA INFORMAÇÃO CONTABILÍSTICA: EVIDÊNCIA EUROPEIA

Cristina Gaio

DOI 10.22533/at.ed.5002003082

CAPÍTULO 3 24

ESTUDO COMPARATIVO ENTRE O ENSINO DA CONTABILIDADE PRESENCIAL E A DISTÂNCIA NO PARAGUAI

Elisiane Alves Fernandes

Dego Hernán Fleitas Recalde

DOI 10.22533/at.ed.5002003083

CAPÍTULO 4

42

A IMPLANTAÇÃO DE UM SISTEMA CONTÁBIL/FINANCEIRO EM UMA OPERADORA DE PLANO DE SAÚDE DA CIDADE DE FORMIGA-MG

Lucas Carrilho do Couto

Fernanda Roberta da Silva

DOI 10.22533/at.ed.5002003084

CAPÍTULO 5 61

PREVISÃO DE INADIMPLÊNCIA UTILIZANDO REGRESSÃO LOGÍSTICA APLICADO A TOMADORES DE CRÉDITO DE UMA INSTITUIÇÃO FINANCEIRA

Jediel Ferreira dos Reis

Vania Corrêa Mota

Irene Yoko Taguchi Sakuno

Josivan Ribeiro Justino

DOI 10.22533/at.ed.5002003085

SOBRE OS ORGANIZADORES

ÍNDICE REMISSIVO 


\section{ANÁLISE BIBLIOMÉTRICA}

Data de aceite: $24 / 07 / 2020$

\section{Caio Augusto Franco Lucas} Universidade Federal da Grande Dourados

Dourados - MS

http://lattes.cnpq.br/1979726893480498

Everton Ferreira Rossi

Universidade Federal da Grande Dourados

Dourados - MS

http://lattes.cnpq.br/8214214962311433

Josimar Pires da Silva

Universidade Federal da Grande Dourados

Dourados - MS

http://lattes.cnpq.br/9929424673911279

Katia Katsumi Arakaki

Universidade Federal da Grande Dourados

Dourados - MS

http://lattes.cnpq.br/5478257556108588

RESUMO: A avaliação de ativos é fundamental para melhor tomada de decisão dos usuários da informação. O presente artigo tem por objetivo analisar pesquisas sobre o termo valuation durante o periodo de 2015 até 2018. A pesquisa contou com abordagem bibliométrica dos artigos com base de dados do Portal da Capes. Por meio dos dados da pesquisa conclui-se que houve redução da quantidade de artigos no período da pesquisa, seja no âmbito nacional, seja no contexto internacional. Em tempo, a maior quantidade de publicações foi realizada nos periódicos brasileiros.

PALAVRAS-CHAVE: Valuation; Portal da Capes; Análise bibliométrica

\section{VALUATION ANALYSIS}

ABSTRACT: Asset valuation is essential for the best decision by information users. This article aims to analyze research on term evaluation during the period from 2015 to 2018 . A survey reported using a bibliometric approach to articles based on data from Portal da Capes. Through the completed survey data, there was a reduction in the number of articles in the research period, either at the national or international level. In progress, the largest number of publications was made in Brazilian journals.

KEYWORDS: Valuation; Capes Portal; Bibliometric Analysis

\section{I INTRODUÇÃO}

As atuais teorias de valuation na contabilidade são baseadas em Ohlson (1995) Modelo de avaliação do lucro residual (ALR). Integrado a isso existe as normas do International Accounting Standards Boards (IASB), as International Financial Reportings 
Standards (IFRS), que facilitam na flexibilidade das normas contábeis e a ação conjunta dos mercados de capitais do mundo inteiro, sem que necessariamente seu capital esteja alocado ao pais que reside (Martins, 2006).

A avaliação de empresas e de investimentos - valuation se tornou assunto de importante discussão para gestores e investidores a fim de maximizar os lucros e sua rentabilidade (Assaf, 2012). Assim as precedências da gestão financeira se tornaram as variavéis determinantes de valor, como por exemplo, giro de investimentos, margem de lucro e rentabilidade, satisfação dos clientes, intangíveis, entre outros.

Ao indicar multiplas variavéis, os analistas colocam em evidência o preço de mercadoe um direcionador de valor correspondente (Schreiner \& Spremann, 2007). Finalizar acordos em mercados emergentes é muito mais arriscado do que em mercados desenvolvidos (PwC, 2012). Algumas variavéis são responsáveis por dificultar essa análise no mercado emergente como por exemplo, volatilidade cambial, medidas de mercado não confiáveis e diferenças contábeis (Damodaran, 2009).

Nesse sentido o tema abordado será trabalhado com o termo "valuation analysis" e na base de dados do Portal da Capes. A pesquisa analisa o termo "valuation analysis" e após a compilação de dados, avaliar a produção científica nacional e internacional a respeito do valuation ou avaliação de empresas.

\section{I FUNDAMENTAÇÃO TEÓRICA}

A finalidade de uma avaliação é estimar o valor justo de um ativo. Sendo o valor justo o valor recebido pela venda de um ativo ou o valor pago pela transferência de um passivo em uma transação não forçada entre participantes do mercado na data da mensuração (CPC 46). A premissa de um bom investimento é não pagar além do valor justo de um ativo. Uma consequência disso é a inevitabilidade de tentar avaliar antecipadamente o que se objetiva comprar (DAMODARAM, 2012). A tendência global nas normas contábeis é da fair value accounting deixando de lado, mas não excluindo o custo histórico. Desse modo se faz necessário àqueles que leem, analisem e formulem as demonstraçoes contábeis ter um pouco de conhecimento sobre noções de avaliação.

Os calculos de avaliação devem se basear na expectativa dos fluxos de caixa futuros. O valor de uma empresa provém das expectativas futuras de desempenho, e o fato de inexistir lucros em certos hiatos de tempo não deve interferir no valor calculado. Uma prova disso é a observação de que muitas empresas conseguem elevar o valor de suas ações na bolsa de valores mesmo em períodos de baixos lucros, ou até de apuração de prejuízos (ASSAF, 2017).

Conforme Assaf (2017), "o processo de avaliação de empresas exige o domínio de conceitos econômicos e financeiros, de técnicas de cálculo e de inúmeros fatores internos e externos à empresa que influem em seu valor econômico, inclusive considerações de 
natureza subjetiva". Tendo a premissa que a avaliação leva em conta fatos subjetivos, pode-se surgir opiniões pré-existentes sobre o ativo que podem trazer interpretações errôneas. Desse modo, o desfecho da interpretação dos calculos tende a refletir os vieses do avalista (DAMODARAM, 2012) gerando conflitos de interesses o que é explicado pela teoria da agência de Alchian e Demsetz (1972). Por vários motivos as estimativas de valor não condirão com os resultados da realidade futura. Sendo assim o ativo apresentará desempenho melhor ou pior que o esperado.

A avaliação de uma empresa é utilizada em situações de reestruturação da empresa, por exemplo, casos de assessoria em fusões e aquisições; assessoria de compra e venda de participações minoritárias; abertura e fechamento de capital e liquidação judicial. Utiliza-se também para fornecer decisões de investimento e financiamento, como em análises de parcerias e joint ventures; análise de viabilidade de projetos de investimento; financiamento, crédito e emissão de debêntures. No mercado secundário de ações é bastante empregado na determinação do preço de compra e venda de ações. E em menor grau usa-se na gestão da empresa para análise de gestão de valor e Planejamento fiscal (MARTELANC et al., 2005).

O crescimento das operações de fusões e aquisições registrado nos últimos anos resultou no fato de uma das principais funções da avaliação de empresas ser fornecer uma faixa de referência de valor da empresa que servirá como base nas negociações de fusões e aquisições (MARTELANC et al., 2005). A avaliação de empresas ganhou grande notoriedade no Brasil a partir de 1993 devido ao grande processo de privatização da economia brasileira (CERBASI, 2003). Para investimentos em ações a analise de valuation, que complementa a analise fundamentalista, possibilita verificar se o preço da empresa no presente está caro ou barato e assim ajuda a tomar decisões para se posicionar e lucrar com elas no futuro (NUNES, 2013).

Ao mínimo três elementos são fundamentais para se fazer um bom valuation, são eles: gerações de caixa, crescimento esperado dessas gerações de caixa e taxa de desconto que reflita o risco dessas gerações de caixa (DAMODARAM, 2013).

Segundo Müller e Teló (2003), há modelos de avaliação baseado no balanço patrimonial, na demonstração de resultado, no googwill, no fluxo de caixa e em criação de valor. E cada modelo possui vários cálculos e métricas diferente. Os autores apresentam uma breve síntese dos mais utilizados informando seus prós e contras, e conclui o artigo afirmando que os modelos não são alternativos e sim complementares.

Tendo em vista o grande número de métodos, a decisão de se optar por um em detrimento de outro geralmente se baseia em limitações das informações disponíveis ou dos instrumentos de avaliação (CERBASI, 2003). 


\section{I METODOLOGIA}

Segundo Vanti (2002) a análise bibliométrica pode ser utilizada para que sejam identificadas as potencialidades de temáticas de pesquisa, de instituições, grupos de pesquisa e cientistas que trabalham com determinado assunto. Para esta pesquisa, optou-se pela utilização da CAPES - Coordenação de Aperfeiçoamento de Pessoal de Nível Superior, considerando que a plataforma contém juntos buscadores do EBSCO, Portal de Periodicos e Scholar Google.

A coleta dos metadados dos artigos foi realizada entre os dias 23 de outubro de 2018 a 26 de outubro de 2018, na qual foram selecionados apenas o tipo de recurso 'Artigos' e estabeleceu - se um recorte temporal desde o ano de 2015 até o ano de 2018.

A expressão de busca para a coleta de dados foi realizado da seguinte forma: A expressão principal foi 'Valuation' e 'Valuation Business' para a coleta de artigos internacionais, 'Valuation' e 'Avaliação de Empresas' (tradução literal) para artigos nacionais, para que se mantessem um padrão de pesquisa.

Os tópicos de pesquisa foram 'Economics', 'Business', 'Accounting' e 'Decision Making' para artigos internacionais e a tradução literal dos tópicos para artigos nacionais. Para corresponder melhor com as necessidades da metodologia, foi utilizado um filtro de busca personalizado onde foi selecionado apenas a opção 'Business \& Economics'. Nos artigos nacionais, após utilizado todas as variavéis de pesquisa chegamos ao resultado total de 19 (dezenove) artigos nacionais onde todos foram pré-selecionados, porém foram retirados artigos publicados em mais de uma revista e artigos fora do tema "empresas" e assim sobraram 16 pesquisas que foram utilizados como amostra dos gráficos e tabelas. E usando as mesmas variações chegamos ao resultado total da população de 640 (seiscentos e quarenta) onde uma amostra de 40 (quarenta) foram pré-selecionados e 20 (vinte) foram utilizados na amostragem final, o descarte dos artigos pré-selecionados se deve pela disparidade entre amostras selecionadas nacionais e internacionais, buscando a melhor interpretação da análise, aproximamos a quantidade de artigos internacionais e nacionais para que houvesse uma equidade quantitativa representada nos gráficos.

\section{I RESULTADOS E DISCUSSÕES}

A partir das buscas de trabalhos, foram selecionados uma amostra de 36 (trinta e seis) artigos no total, sendo 16 (dezesseis) nacionais e 20 (vinte) internacionais. A Figura 1 apresenta a quantidade de artigos publicados, divididos em nacionais e internacionais, em cada ano de pesquisa. A Figura destaca que houve uma decadência nas publicações sobre valuation ao longo dos anos. Esse fato pode ser explicado pela convergencia dos pesquisadores para outras pesquisas positivistas. 


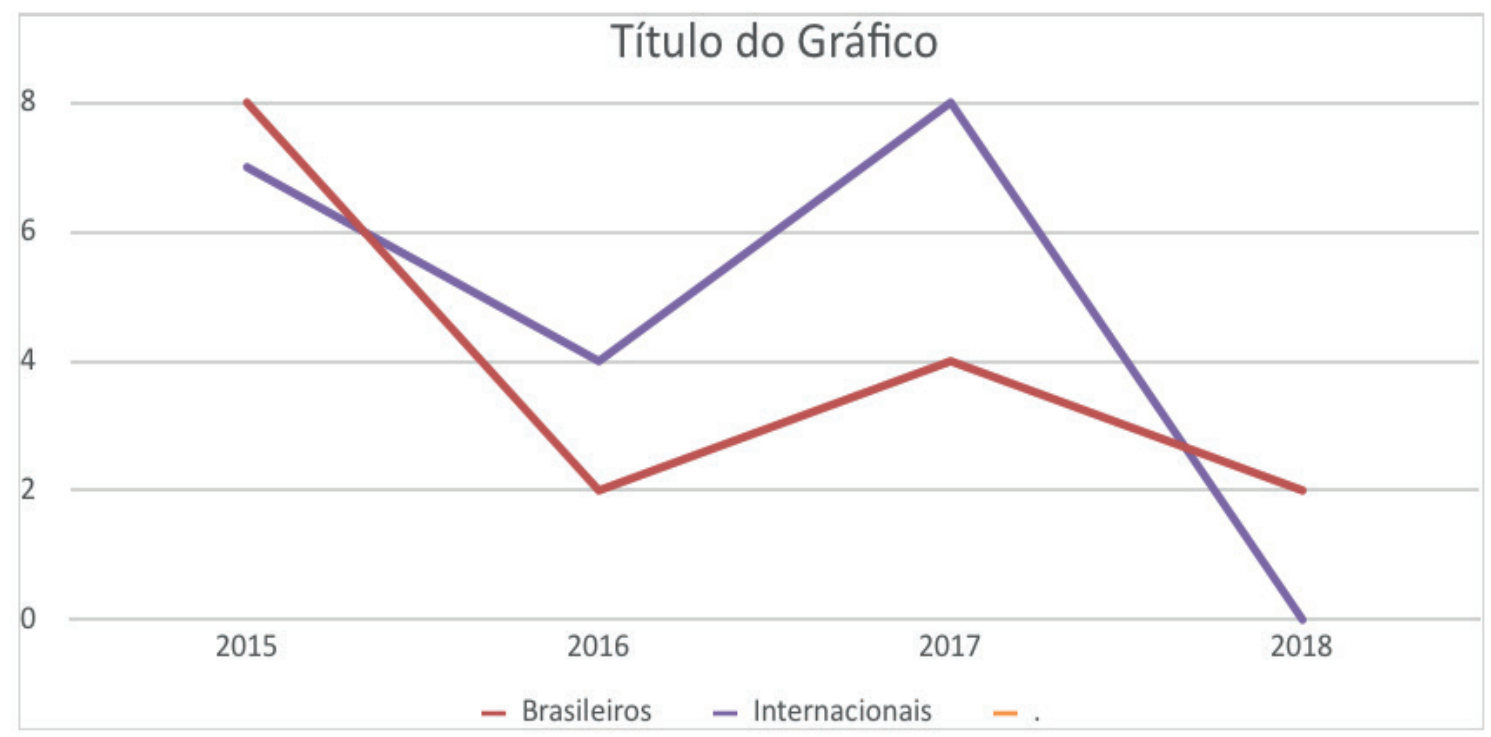

Figura 1 - Evolução da quantidade de publicações sobre valuation Fonte: Elaboração própria com base no Portal Capes

Em relação a distribuição das pesquisas realizadas nos diversos países, a tabela 1 demonstra que a pesquisa sobre valuation foi bem difundida no mundo. No entanto, destacam-se Estados Unidos e a Alemanha e o brasil, que entra nessa tabela para efeito de demonstração já que representa o total de artigos encontrados de acordo com o critério de seleção.

Cumpre destacar a presença de alguns países sub-desenvolvidos, como a Colombia e Tailândia, apresentando proporções equivalente a paises desenvolvidos como Inglaterra e Romênia e, a ausência de outros desenvolvidos, sobretudo em relação a pesquisas contábeis.

\begin{tabular}{ccc}
\hline Ranking & País & Registros \\
\hline $\mathbf{1}$ & Brasil & 16 \\
\hline $\mathbf{2}$ & EUA & 8 \\
\hline $\mathbf{3}$ & Alemanha & 3 \\
\hline $\mathbf{4}$ & Colômbia & 2 \\
\hline $\mathbf{5}$ & Romênia & 2 \\
\hline $\mathbf{6}$ & Inglaterra & 2 \\
\hline $\mathbf{7}$ & Austrália & 1 \\
\hline $\mathbf{8}$ & Singapura & 1 \\
\hline $\mathbf{9}$ & Tailândia & 1 \\
\hline $\mathbf{1 1}$ & Irã & 1 \\
\hline
\end{tabular}

Tabela 1 - Países de origem das instituições onde foram publicadas as revistas Fonte: Elaboração própria com base no Portal Capes

Do ponto de vista da públicação em periódicos, na Tabela 2 são apresentados os períodicos brasileiros com maiores quantidades de publicações sobre avaliação de 
empresas. Os mais representativos são: a Revista Gestão Finanças e Contabilidade da UNEB - Universidade do Estado da Bahia; a Revista de Gestão e Projetos da Universidade privada Uninove; e a Revista Brasileira de Finanças, da também privada Fundação Getulio Vargas (FGV). As revistas internacionais não entraram nesta tabela porque apenas duas tiveram trabalhos sobre valuation publicados mais de uma vez (Journal of Financial Economics e a Managerial Finance).

\begin{tabular}{ccc}
\hline Ranking & Revista & Registros \\
\hline $\mathbf{1}$ & Gestão Finanças e Contabilidade & 3 \\
\hline $\mathbf{2}$ & Revista de Gestão e Projetos - GeP & 3 \\
\hline $\mathbf{3}$ & Revista Brasileira de Finanças & 2 \\
\hline $\mathbf{4}$ & Fatec Zona Sul & 1 \\
\hline $\mathbf{5}$ & RAC & 1 \\
\hline $\mathbf{6}$ & RAE & 1 \\
\hline $\mathbf{7}$ & Revista catarinense da ciência contábil & 1 \\
\hline $\mathbf{8}$ & Revista Científica Hermes & 1 \\
\hline $\mathbf{9}$ & Revista Contabilidade e Finanças & 1 \\
\hline $\mathbf{1 0}$ & Revista brasileira de gestão de negócios & 1 \\
\hline 11 & ANPAD & 1 \\
\hline
\end{tabular}

Tabela 2 - Ranking dos periódicos nacionais com maior quantidade de publicações

Fonte: Elaboração própria, a partir de dados coletados do Portal Capes

Em relação as citações, a Tabela 3 mostra a quantidade de citações. Mesmo tendo uma porcentagem maior de artigos como amostra, os trabalhos brasileiros não são os mais citados. Destaca-se, entre os brasileiros, o artigo de Márcio machado, Macedo e Márcia Machado, Análise da Relevância do Conteúdo Informacional da DVA no Mercado Brasileiro de Capitais, sendo o único artigo publicado na Revista Contabilidade e Finanças da USP. O artigo maior natabilidade refere-se a Valuation Risk of finance model Asset pricing, de Rui Albuquerque; Martin Eichenbaum; Victor Xi Luo; Sergio Rebelo, com 95 citações.

\begin{tabular}{llc}
\hline \multicolumn{1}{c}{ Autores } & \multicolumn{1}{c}{ Título } & Citações \\
\hline $\begin{array}{l}\text { Rui Albuquerque; Martin } \\
\text { Eichenbaum; Victor Xi Luo; } \\
\text { Sergio Rebelo }\end{array}$ & $\begin{array}{l}\text { Valuation Risk of finance model Asset } \\
\text { pricing }\end{array}$ & 95 \\
\hline $\begin{array}{l}\text { Peter Joos; Joseph D. Piotroski; } \\
\text { Suraj Srinivasan }\end{array}$ & $\begin{array}{l}\text { Can analysts assess fundamental risk and } \\
\text { valuation uncertainly? Na empirical analysis } \\
\text { of scenario-based value estimates }\end{array}$ & 17 \\
\hline $\begin{array}{l}\text { Márcio Machado; Macedo; } \\
\text { Márcia Machado }\end{array}$ & $\begin{array}{l}\text { Análise da Relevância do Conteúdo } \\
\text { Informacional da DVA no Mercado }\end{array}$ & 14 \\
\hline $\begin{array}{l}\text { Alberto Longo; David Hoyos; } \\
\text { Anil Markandya }\end{array}$ & $\begin{array}{l}\text { Sequence Effects in the Valuation of } \\
\text { Multiple Environmental Programs Using the }\end{array}$ & 12 \\
\hline
\end{tabular}




\begin{tabular}{llc}
\hline $\begin{array}{l}\text { Naveed Chehrazi; Thomas A. } \\
\text { Weber }\end{array}$ & $\begin{array}{l}\text { Dynamic Valuation of Delinquent Credit- } \\
\text { Card Accounts }\end{array}$ & 8 \\
\hline $\begin{array}{l}\text { Félix; Locatelli; Fernandes; } \\
\text { Ramalho }\end{array}$ & Construção civil no brasil & 7 \\
\hline $\begin{array}{l}\text { Vallejo-Alonso;García- } \\
\text { Merino;Arregui-Ayastuy }\end{array}$ & $\begin{array}{l}\text { Motives for Financial Valuation of } \\
\text { intangibles and business performance in } \\
\text { Smes }\end{array}$ & 6 \\
\hline Moreira; Locatelli; Afonso & $\begin{array}{l}\text { Avaliação e gestão econômico-financeira } \\
\text { de projetos: um estudo aplicado ao setor } \\
\text { metalúrgico }\end{array}$ & 5 \\
\hline Pimentel; Aguiar & $\begin{array}{l}\text { The role of earnings persistence in } \\
\text { valuation accuracy and the time horizon }\end{array}$ \\
\hline
\end{tabular}

Tabela 3 - Publicações mais citadas

Fonte: Elaboração própria, a partir de dados coletados do Portal Capes

Por fim, a Tabela 4 demonstra a quantidade de autores por artigo. A maioria dos artigos analisados foram feitos por 2 ou 3 autores, correspondendo respectivamente a 38,89\% e $30,55 \%$. Da totalidade dos artigos, apenas $13,89 \%$ foram realizados individualmente, demonstrando uma tendencia nas pesquisas científicas, enfatizando a necessidade discussão das ideias.

\begin{tabular}{l|l|l}
\hline $\mathbf{N}^{\circ}$ de autores & Artigos & $\%$ \\
\hline $\mathbf{1}$ & 5 & $13,89 \%$ \\
\hline $\mathbf{2}$ & 14 & $38,89 \%$ \\
\hline $\mathbf{3}$ & 11 & $30,55 \%$ \\
\hline $\mathbf{4}$ & 6 & $16,67 \%$ \\
\hline Total & 36 & $100,00 \%$ \\
\hline
\end{tabular}

Tabela 4 - Número de autores por artigo

Fonte: Elaboração própria, a partir de dados coletados do Portal Capes

\section{I CONSIDERAÇÕES FINAIS}

O assunto valuation que tem uma área de aplicação e métodos tão vastos, que permite identificar quais os principais estudiosos do tema, áreas pesquisadas e métodos mais eficientes. Isso tudo é de grande valia para que negócios sejam feitos sem que os compradores ou vendedores saiam prejudicados. $O$ presente artigo analisou pesquisas contendo o termo valuation.

O trabalho conclui que do ano de 2015 a 2018 houve uma diminuição na quantidade de pesquisas científicas sobre o tema valuation, sendo isso algo natural, pois o tema adquiriu uma importância nunca vista antes o que fez o assunto ter uma crescente de pesquisas no final do século passado, principalmente pelo surgimento de novas tecnologias e intangíveis que dificultam a valoração de empresas que detêm esses ativos, e também pela privatização da economia brasileira, aquisições e fusões entre concorrentes. 
Em tempo, a decréscimo de publicação é observado no âmbito nacional e também internacional. Vale reportar que a análise possui como limitação o pequeno período de análise e contando com base secundária. Outro ponto de destaque, alta concentração de citações em poucos trabalhos da área.

Para novas pesquisas, seria interessante (i) considerar um período maior de análise, (ii) utilização de diversas ferramentas de análise bibliométrica, (iii) utilização de sinônimos para os termos utilizados na pesquisa, (iv) verificar os principais investimentos utilizados para realização da técnica de valuation e v) outros procedimentos metodológicas para pesquisas com foco aplicado (i.e. pesquisa de campo).

\section{REFERÊNCIAS}

CERBASI, G. P. Metodologia para determinação do valor da empresa: uma aplicação no setor de geração de energia hidrelétrica. 2003. Dissertação (Mestrado em Administração) - Departamento de Administração da Faculdade de Economia, Administração e Contabilidade, Universidade de São Paulo, São Paulo.

DAMODARAN, Aswath. Valuation - Como Avaliar Empresas e Escolher as Melhores Ações. LTC, 04/2012. [Minha Biblioteca].

MÜLLER, A. N.; TELÓ, A. R. Modelos de avaliação de empreas. Revista FAE, Curitiba, v. 6, n. 2, p. 97-112, 2003.

MARTELANC, R. et al. Utilização de metodologias de avaliação de empresas: resultados de uma pesquisa no brasil. In: SEMINÁRIO EM ADMINISTRAÇÃO, 8., 2005, São Paulo. Anais... São Paulo: SEMEAD, 2005.

NETO, ASSAF, Alexandre. Valuation - Métricas de Valor \& Avaliação de Empresas, $2^{\mathrm{a}}$ edição. Atlas, 01/2017. [Minha Biblioteca].

NUNES, M. A. L. Precificação relativa de ações: analise de carteira de ações baseada em valuation. 2013. Monografia (Bacharel em Administração) - Curso de Administração, Universidade Federal do Rio Grande do Sul, Porto Alegre.

Ohlson, J. A. (1995), 'Earnings, Book Values, and Dividends in Equity Valuation', Contemporary Accounting Research, Vol. 11, No. 2,

Schreiner, Andreas et Spremann, Klaus, Multiples and Their Valuation Accuracy in European Equity Markets (August 13, 2007). Available at SSRN: https://ssrn.com/abstract=957352 or http://dx.doi.org/10.2139/ ssrn.957352

Martins E. Contabilidade de custos. São Paulo: Atlas; 2006.

PwC, PricewaterhouseCoopers. Ideias e tendências: Práticas atuais de gestão de projetos, portfólios e programas. Terceira pesquisa global sobre a gestão de projetos, 2012.

DAMODARAN, Aswath. Investment valuation: Tools and techniques for determining the value of any asset. John Wiley \& Sons, 2012. 


\section{O IMPACTO DA ADOÇÃO DAS IFRS NA RELEVÂNCIA DA INFORMAÇÃO CONTABILÍSTICA: EVIDÊNCIA EUROPEIA}

Data de aceite: $24 / 07 / 2020$

\section{Cristina Gaio} Advance/CSG, ISEG, Universidade de Lisboa

Catarina Alhinho

ISEG, Universidade de Lisboa

Resumo: Este estudo tem como objetivo analisar o impacto da adoção obrigatória das IFRS na relevância da informação contabilística num conjunto de 14 países europeus. Para tal, analisou-se a associação entre as variáveis contabilísticas, Book Value Per Share E Earnings Per Share, com o valor da cotação das ações das empresas (Market Price), metodologia seguida por Barth et al. 2005. Os resultados sugerem uma melhoria na relevância da informação contabilística na Alemanha, França, Portugal, Bélgica, Finlândia, Grécia, Áustria, Holanda, Reino Unido e Irlanda. No entanto, para a Noruega, Suécia, Espanha e Dinamarca esta melhoria não se verifica. Adicionalmente, este estudo indica que os países Anglo-Saxónicos apresentam maior relevância da informação contabilística face aosContinentais.

PALAVRAS-CHAVE: IFRS, Relevância, Europa, Países Anglo-Saxónicos vs Continentais.

Abstract: The goal of this paper is to analyze the impact of the mandatory adoption of IFRS in the relevance of accounting information in 14 European countries. To achieve this, it was analyzed the association between the accounting variables Book Value per Share and Earnings per Share, and the Market Price of the firm, method used by Barth et al. 2005. The results suggest an improvement in the relevance of accounting information in Germany, France, Portugal, Belgium, Finland, Greece, Austria, Netherlands, UK and Ireland. However, for Norway, Sweden, Spain and Denmark this improvement does not occur. Furthermore, this paper indicates that the Anglo-Saxon countries reveal a greater relevance of accounting information compared to Continental ones.

KEYWORDS: IFRS, Relevance, Europe, AngloSaxon vs. Continental countries.

\section{I INTRODUÇÃO}

Um dos marcos mais importantes da história da informação contabilística foi a obrigatoriedade de adoção das normas internacionais de relato financeiro (IFRS) nos países da União Europeia (UE). De facto, a partir de Janeiro de 2005, e de acordo com o Regulamento n 1606/2002 do Parlamento Europeu e do Conselho, todas as empresas cotadas teriam de adotar o normativo 
internacional no processo de consolidação de contas.

A adoção das IFRS na UE teve como principal objetivo a harmonização da informação financeira, de forma a que as demonstrações financeiras se tornassem mais comparáveis e de melhor qualidade, e assim contribuir para um melhor funcionamento dos mercadosfinanceiros.

No entanto, estudos revelam que as normas por si só não garantem a qualidade da informação contabilística, pois existem outros fatores, para além da qualidade do normativo, que afetam a sua aplicação e a qualidade da informação relatada. Num estudo realizado logo após a adoção obrigatória das IFRS nas empresas cotadas europeias, Glaum et al. (2008) concluíram que existia uma considerável variação do nível de conformidade com as normas. Também em termos de consequências económicas da adoção das IFRS os resultados podem divergir. Daske et al. (2009) concluíram que a liquidez dos mercados aumenta no momento de adoção das normas, mas que o custo de capital diminui apenas em países onde os incentivos para as empresas serem mais transparentes são maiores e o nível de proteção legal ao investidor é superior.

As demonstrações financeiras devem apresentar diversas características qualitativas, tais como a compreensibilidade, a comparabilidade, a relevância e a fiabilidade. Todas estas características são fundamentais para que a informação contabilística tenha qualidade, nomeadamente a relevância que é uma característica necessária, pois a informação contabilística tem de ser útil na tomada de decisões económicas de um leque variado de utilizadores das demonstrações financeiras (investidores, financiadores e outros credores potenciais e efetivos). Desta forma, a informação financeira considerase útil quando é relevante e representar fielmente o que pretende representar (ou seja, a informação tem de ser completa, neutra e livre de erros). Assim, a utilidade da informação financeira é melhorada quando é comparável, verificável, tempestiva e compreensível (Estrutura Conceptual dolASB).

$\mathrm{Na}$ literatura existente, a relevância tem sido predominantemente estudada através da associação entre os valores de mercado e os valores contabilísticos. Ou seja, existe maior relevância da informação contabilística quanto maior for a associação entre o preço das ações, ou rendibilidade, e os valores contabilísticos (Barth et al, 2001).

Este estudo tem como objetivo principal analisar o impacto da adoção obrigatória das IFRS na relevância da informação contabilística de empresas cotadas europeias. Para tal, foram realizadas três análises: análise por país, em que se estuda para cada país o impacto da adoção das IFRS; análise nos países Anglo-Saxónicos e nos Continentais, em que se estuda a influência da adoção das IFRS nestes países em separado; e análise comparativa entre países Anglo-Saxónicos eContinentais.

A metodologia seguida foi a de Barth et al. (2005), que consiste na associação entre as variáveis contabilísticas Book Value Per Share e Earnings Per Share, com o valor da cotação das ações das empresas (Market Price). A amostra é composta por 1640 
empresas cotadas de 14 países da Europa, sendo o período amostral dividido em dois: o período anterior à adoção das IFRS (1999 a 2004), e posterior à adoção (2005 a2012).

Os resultados obtidos sugerem uma melhoria na relevância da informação contabilística na Alemanha, França, Portugal, Bélgica, Finlândia, Grécia, Áustria, Holanda,

Reino Unido e Irlanda. No entanto, para a Noruega, Suécia, Espanha e Dinamarca esta melhoria não se verifica. No grupo de países Anglo- Saxónicos, os resultados revelam que, com a adoção obrigatória das IFRS, a relevância da informação contabilística diminuiu, ao contrário do que acontece no grupo de países Continentais em que se verifica um aumento. No entanto, na comparação entre os dois grupos de países, conclui-se que as empresas dos países Anglo-Saxónicos apresentam maior relevância na informação contabilística do que as dos países Continentais nos dois períodos em análise. Este trabalho encontrase organizado em cinco secções. Na secção 2, é feita uma breve revisão da literatura e apresentadas as questões de investigação. Na secção 3, é feita a descrição da amostra e da metodologia utilizada. Na secção 4, apresentam-se e analisam-se os resultados empíricos. Por fim, na secção 5 apresentam-se asconclusões.

\section{I REVISÃO DA LITERATURA}

\subsection{O efeito das IFRS na relevância e na qualidade da informação contabilística}

Amir et al. (1993) utilizaram o termo value relevance (valor relevante) para descrever a associação entre os valores de mercado e os valores contabilísticos. Desta forma, o valor relevante passou a ser uma medida em diversos estudos como uma das proxies para avaliar a qualidade da informação contabilística (Barth et al., 2005).

O impacto da adoção voluntária ou obrigatório das IFRS na qualidade da informação contabilística, mais concretamente na sua relevância, tem sido alvo de diversos estudos.

A maioria dos estudos que analisa a realidade europeia são feitos para empresas de um único pais (Bartov et al., 2005; Schiebel, 2007; Callao et al., 2007; Morais \& Curto, 2008; Paananen \& Lin, 2009; Christensen et al., 2015), sendo ainda escassos os que tem uma abordagem internacional (Barth et al., 2005; Jeanjean \& Stolowy, 2008; Devalle et al., 2010). No entanto, a evidencia empírica tem-se manifestado inconsistente, pois alguns estudos revelam um impacto positivo do normativo internacional na relevância da informação, enquanto outros um impacto negativo ou mesmo nenhum impacto. Entre outros fatores, a diversidade de resultados e conclusões pode resultar do uso de amostras, períodos e metodologias distintas.

Bartov et al. (2005) analisaram a relevância da informação de empresas alemãs baseada em três normativos: alemão, IFRS e norte americano. Os resultados permitiram concluir que os valores baseados nas IFRS e no normativo americano são mais relevantes que os valores baseados no normativo alemão. No entanto, Schiebel (2007), que também 
examinou a relevância da informação contabilística na Alemanha, concluiu que as normas alemãs são significativamente mais relevantes que as IFRS.

Devalle et al. (2010) estudaram a relevância da informação contabilística numa amostra de empresas de 5 países da UE, tendo chegado a resultados mistos. Por um lado, em termos de earnings per share (EPS), os resultados obtidos revelam que há uma melhoria na relevância da informação contabilística após a adoção das IFRS no Reino Unido, França e Alemanha. Por outro lado, em termos de book value (BV), há uma diminuição da relevância da informação contabilística na Itália, França, Alemanha e Espanha, sendo que apenas o Reino Unido apresenta umaumento.

Muitos estudos que analisam a relevância da informação contabilística estudam também outras medidas de mensuração da qualidade da informação financeira, como sejam a gestão de resultados e o conservadorismo. Por exemplo, Barth et al. (2005) estudaram as consequências da adoção das IFRS numa amostra de 21 países. Os resultados obtidos demonstraram que as empresas que adotaram voluntariamente as IFRS revelaram um menor nível de gestão de resultados, maior conservadorismo e maior relevância dos valores contabilísticos, ou seja, o impacto da adoção do normativo internacional foi positivo na qualidade dainformação.

Por sua vez, Paananen \& Lin (2009), que tinham como objetivo estudar o impacto da adoção obrigatória e voluntária das IFRS nas empresas alemãs, verificaram que a adoção destas normas fez com que houvesse um decréscimo da qualidade da informação contabilística, pois a gestão de resultados aumentou, o reconhecimento de perdas mais atempadamente não se verificou e a relevância da informação contabilística piorou. Já Christensen et al. (2015), que também analisaram as consequências da adoção das IFRS nas empresas alemãs, concluíram que o normativo internacional não teve um impacto positivo em três dimensões de qualidade de resultados: gestão de resultados, conservadorismo e relevância da informaçãocontabilística

Também Morais \& Curto (2008) analisaram o nível de gestão de resultados e a relevância da informação contabilística numa amostra de empresas cotadas portuguesas entre 1995 e 2005. Os resultados obtidos sugerem uma redução quer da gestão da resultados quer da relevância da informação contabilístico. No entanto, os autores alertam para o facto dos resultados poderem estar enviesados, devido ao período de pós-adoção das IFRS conter apenas o ano de 2005. De forma semelhante, Callao et al. (2007), ao estudarem empresas espanholas entre 2004 e 2005, verificaram que a adoção das IFRS teve um impacto negativo na comparabilidade e relevância da informação contabilística. Já Jeanjean \& Stolowy (2008) analisaram uma amostra internacional de empresas australianas, francesas e inglesas que adotaram pela primeira vez as IFRS (2004-2005), e concluíram que a qualidade da informação contabilística não sofreu alterações para a Austrália e Reino Unido. Já em França, os resultados revelaram um aumento da gestão de resultados contribuindo assim para a diminuição da qualidade da informação contabilística 
após a adoção das IFRS.

Em suma, encontram-se muitas divergências nos resultados obtidos pelos diversos estudos sobre a qualidade da informação contabilística acima referidos. Hung (2000), Leuz et al. (2003) e Ball et al. (2003) apontam como possíveis causas para esta diversidade, entre outros fatores institucionais, as diferentes políticas de divulgação e as leis de proteção ao investidor.

\subsection{A origem legal na explicação e o nível de relevância dainformação}

Nas últimas décadas, a UE tem promovido a harmonização contabilística no espaço europeu, nomeadamente através das Diretivas Comunitárias e do Regulamento $\mathrm{n}^{\circ}$ 1606/2002. No entanto, existem várias causas para a diversidade contabilística, entre as quais a origem legal do país (Leuz et al., 2003; Hung, 2000; Ball et al., 2003) que podem condicionar os efeitos desejáveis da harmonização contabilística.

Nobes (1998) e Nobes \& Parker (1998) classificam os sistemas contabilísticos em dois grandes grupos, com base na origem legal: o modelo Continental e o modelo Anglosaxónico. As principais diferenças entre estes dois sistemas encontram-se sumarizados no Quadro I.

\begin{tabular}{|c|c|}
\hline Modelo Continental & Modelo Anglo-saxónico \\
\hline Direito Romano (baseado em regras) & Direito Inglês (baseado em princípios) \\
\hline Pequenos mercados de capital & Grandes mercados de capitais \\
\hline Contabilidade orientada para o credor & Contabilidade orientada para o investidor \\
\hline Reduzido nível de divulgação de informação & Elevado nível de divulgação de informação \\
\hline $\begin{array}{l}\text { Forte ligação entre a fiscalidade e a } \\
\text { contabilidade }\end{array}$ & $\begin{array}{l}\text { Separação entre a contabilidade e a } \\
\text { fiscalidade }\end{array}$ \\
\hline Normalização: Estado & Normalização: entidades privadas \\
\hline $\begin{array}{l}\text { Países: Portugal, França, Alemanha, } \\
\text { Bélgica, Finlândia, Grécia, Noruega, } \\
\text { Suécia, Áustria, Espanha, Holanda, Suíça, } \\
\text { Luxemburgo e Japão }\end{array}$ & $\begin{array}{l}\text { Países: Reino Unido, Canadá, Austrália, } \\
\text { Dinamarca, Irlanda e Estados Unidosda } \\
\text { América }\end{array}$ \\
\hline
\end{tabular}

Quadro I - Sistemas contabilísticos

Fonte: Elaboração própria com base em Nobes et al. (1998).

Alford et al. (1993) demonstraram que a associação entre os valores contabilísticos e as cotações de mercado é mais forte em países com grandes mercados de capitais e onde a contabilidade não está relacionada com a fiscalidade, ou seja, países tradicionalmente conhecidos por Anglo-Saxónicos. Adicionalmente, Ali \& Hwang (2000) demonstraram que a relevância da informação financeira é menor em países onde os sistemas financeiros 
são orientados para a banca, onde os organismos do setor privado não estão envolvidos no processo de definição das normas, e onde a fiscalidade e a contabilidade estão intimamente relacionadas, fatores que caracterizam o modelo Continental. Também Ball et al. (2001) concluíram que o modelo orientado para o investidor, ou seja, o AngloSaxónico, apresenta geralmente maior relevância da informação contabilística.

Já Hung (2000) analisou a relação entre a proteção dos acionistas e a relevância da informação contabilística numa amostra internacional de empresas de 21 países, sendo que os resultados permitiram concluir que o valor relevante das demonstrações financeiras é inferior nos países com nível mais baixo de proteção aos acionistas, ou seja, nos países do modelo Continental. Também La Porta et al. (2002) chegaram a conclusões semelhantes ao comprovarem que várias rubricas contabilísticas apresentam maior relevância nos países baseados em "common law”, uma vez que as leis de proteção ao investidor são melhores.

A ideia de que o nível de proteção ao investidor é um importante determinante da relevância da informação contabilística num dado país é também partilhada por muitos outros autores, como por exemplo Hung \& Subramanyam (2004) e Narktabtee \& Patpanichchot (2011).

\subsection{Questões deinvestigação}

Este estudo tem como objetivo principal analisar o impacto da adoção obrigatória das IFRS na relevância da informação contabilística na Europa. Em primeiro lugar, é feita uma análise por país cujo objetivo é perceber, para cada país da amostra, se com a adoção das IFRS houve o aumento expectável na relevância da informação contabilística. De acordo com a revisão da literatura efetuada, os estudos sobre o impacto das IFRS na relevância da informação contabilística, realizados em vários países e em diversos períodos amostrais, apresentaram resultados mistos. Desta forma, torna-se pertinente fazer uma análise às consequências na relevância da informação contabilística de cada país para o mesmo período amostral e para um período mais longo, pois já passaram sete anos desde a adoção obrigatória das IFRS. Assim, a nossa primeira questão de investigação (QI) é formulada da seguinte forma:

QI $_{1}$ : A relevância da informação contabilística é superior no período posterior à adoção das IFRS?

Em segundo lugar, pretende-se perceber se o impacto da adoção das IFRS na relevância da informação contabilística foi diferente para os países Continentais e para os países Anglo-Saxónicos. Os estudos anteriores têm sugerido que as empresas dos 
países Anglo-saxónicos apresentam maior relevância contabilística depois da adoção das IFRS (Narktabtee \& Patpanichchot, 2011; Fontes et al., 2005). Já para os países Continentais, as conclusões dos estudos são mistas, consoante os países e o período temporal analisado (Callao et al., 2007; Jeanjean \& Stolowy, 2008; Paananen \& Lin, 2009; Devalle et al.,2010).

Desta forma, pretendemos responder às seguintes questões de investigação:

$\mathbf{Q I}_{2}$ : A relevância da informação contabilística das empresas dos países AngloSaxónicos é superior no período posterior à adoção das IFRS?

QI $\mathbf{I}_{3}$ : A relevância da informação contabilística das empresas dos países Continentais é superior no período posterior à adoção das IFRS?

Em terceiro lugar, é feita uma análise que tem como objetivo confrontar os dois modelos e perceber qual o grupo que tem maior relevância na informação contabilística antes e após a adoção das IFRS. Uma vez que a literatura apresenta diversos estudos que concluem que os países Anglo-Saxónicos apresentam maior relevância da informação contabilística que os países Continentais (Ali \& Hwang, 2000; Ball et al., 2001; Alford et al, 1993; Narktabtee \& Patpanichchot, 2011), coloca-se a quarta questão de investigação:

QI : A relevância da informação contabilística das empresas dos países AngloSaxónicos é superior à das empresas dos países Continentais antes e após a adoção das IFRS?

\section{I METODOLOGIA}

\subsection{Amostra edados}

A amostra inicial deste estudo é constituída por todos os países da UE que de acordo com Nobes (1998) e Nobes \& Parker (1998) se enquadram no modelo Continental e AngloSaxónico ${ }^{1}$. Assim, a amostra encontra-se dividida entre países Continentais (Alemanha, Áustria, Bélgica, Espanha, Finlândia, França, Grécia, Portugal, Holanda, Luxemburgo, Noruega e Suécia) e países Anglo- Saxónicos (Dinamarca, Irlanda e Reino Unido).

A amostra é também dividida em dois períodos amostrais distintos, o período préadoção das IFRS (1999 - 2004) e o período pós-adoção das IFRS (2005 - 2012). Foram excluídas da amostra todas as empresas com falta de dados e as que pertenciam ao setor da banca, seguros, empresas de investimentos e clubes de futebol, uma vez que as suas demonstrações financeiras apresentam uma estrutura muito própria (Jeanjean \& Stolowy,

1 Por simplificação, passa a chamar-se apenas países Continentais e Anglo-Saxónicos 
2008).

Com o objetivo de tornar possível a comparação antes e após a adoção das IFRS, excluíram-se também as empresas que não estavam cotadas em bolsa durante todo o período amostral. De seguida, retiraram-se os países que não apresentaram mais de 30 observações, como é o caso do Luxemburgo.

Por último, e de forma a analisar o impacto da adoção obrigatória das IFRS na relevância da informação contabilística, retiraram-se todas as empresas que adotaram voluntariamente as IFRS antes de 2005. Assim, a composição da amostra final por país pode ser visualizada na Tabela I.

\begin{tabular}{|c|c|c|}
\hline País & $\begin{array}{c}\mathrm{N}^{\circ} \text { de } \\
\text { Empresas }\end{array}$ & $\begin{array}{c}\mathrm{N}^{\circ} \text { de } \\
\text { Observações }\end{array}$ \\
Alemanha & 228 & 3192 \\
Áustria & 25 & 350 \\
Bélgica & 53 & 742 \\
Dinamarca & 71 & 994 \\
Espanha & 75 & 1050 \\
Finlândia & 64 & 896 \\
França & 242 & 3338 \\
\hline Grécia & 107 & 1498 \\
\hline Holanda & 67 & 938 \\
Irlanda & 11 & 154 \\
Noruega & 60 & 840 \\
Portugal & 13 & 182 \\
Reino Unido & 452 & 6328 \\
Suécia & 172 & 2408 \\
\hline Total & 1640 & 22960 \\
\hline Tabela I - Composição da amostra por país
\end{tabular}

\subsection{Modelo Empírico}

A literatura sobre a relevância da informação contabilística têm-se suportado fortemente no modelo do preço (Lang et al., 2003; Barth et al., 2005), tendo sido este o modelo escolhido para este estudo. Segundo Barth et al. (2005) a métrica que deve ser utilizada para medir a relevância da informação contabilística deve basear-se numa regressão do preço da ação (price) nos resultados por ação (earnings per share) e no valor contabilístico do capital próprio (book value pershare).

Assim, o modelo de base utilizado para responder às diferentes QI é o seguinte:

$$
P i t+6=\beta 0+\beta 1 \text { BVPS it }+\beta 2 \text { EPS it }+\varepsilon i t
$$


Em que:

$\mathrm{P}_{\mathrm{it}+6}$ - Preço da ação da empresa i seis meses após o final do ano t;

BVPS $_{\text {it }}$ - Valor contabilístico do capital próprio por ação da empresa i no final do ano $\mathrm{t}$

EPS $_{\text {it }}$ - Resultado Líquido por ação da empresa i no final do ano t.

De forma a assegurar que a informação financeira é de domínio público, utilizou-se o Price de seis meses após o fim do ano fiscal (Lang et al, 2003; Barth et al, 2005). O BVPS resulta do quociente entre o valor do capital próprio e o número de ações em circulação. $O$ EPS consiste no quociente entre o resultado líquido e o número de ações em circulação.

Uma vez que a adoção obrigatória das IFRS ocorreu em 2005, a análise vai efetuarse em dois períodos distintos. Assim, o modelo é estimado para o período pré-adoção (1999-2004) e para o período pós-adoção (2005-2012).

Por forma a que os resultados obtidos não sejam distorcidos por valores extremos, para cada variável dos modelos foram identificados e removidos os outliers mais a esquerda (<5\%) e mais à direita (>95\%). O modelo de regressão linear múltipla apresenta como pressupostos a normalidade, a homocedasticidade e a independência, sendo que se verificou estatísticamente estes pressupostos para cadaregressão.

Numa primeira análise dividiu-se as empresas da amostra por país $\left(\mathbf{Q I}_{\mathbf{1}}\right)$. Numa segunda análise as empresas foram agrupadas em dois grupos: países Continentais e países Anglo-Saxónicos, pelo que se adicionou ao modelo variáveis dummy por país, que assumem o valor 1 se a empresa for originária desse país, ou o valor 0 se originária de outro país da amostra, por forma a controlar para as diferentes características institucionais dos países em análise (QI2 e QI3). Finalmente, para responder à QI4, procedeu-se à comparação dos resultados obtidos nas regressões lineares usadas para responder às QI2 e QI3.

\section{I ANÁLISE DOSRESULTADOS}

\subsection{Análise por País}

Esta análise tem como objetivo perceber para cada país da amostra se a relevância da informação contabilística aumentou com a adoção das IFRS. Para cada regressão, por país e por período, os resultados obtidos do F-Test, sugerem que os modelos utilizados são apropriados para descrever a relação entre as variáveis emestudo.

De acordo com Barth et al. (2005) o coeficiente de determinação (R2) é a medida utilizada para medir a relevância da informação contabilística, uma vez que indica a variação que ocorre na variável dependente (Price) devido às variáveis independentes 
(BVPS e EPS). A Tabela II apresenta os R2 ajustados por país e por período.

\begin{tabular}{|c|c|c|}
\hline País & $\mathbf{1 9 9 9 - 2 0 0 4}$ & $\mathbf{2 0 0 5 - 2 0 1 2}$ \\
\hline Alemanha & $51,4 \%$ & $57,9 \%$ \\
Áustria & $47,6 \%$ & $52,5 \%$ \\
Bélgica & $62,8 \%$ & $70,0 \%$ \\
Dinamarca & $49,7 \%$ & $45,8 \%$ \\
Espanha & $54,4 \%$ & $38,2 \%$ \\
Finlândia & $44,0 \%$ & $52,4 \%$ \\
França & $50,7 \%$ & $58,1 \%$ \\
Grécia & $15,7 \%$ & $39,9 \%$ \\
Holanda & $39,8 \%$ & $52,4 \%$ \\
Irlanda & $55,4 \%$ & $75,8 \%$ \\
Noruega & $47,5 \%$ & $46,8 \%$ \\
Portugal & $43,8 \%$ & $54,1 \%$ \\
Reino Unido & $42,9 \%$ & $55,3 \%$ \\
Suécia & $56,2 \%$ & $51,0 \%$ \\
\hline
\end{tabular}

Tabela II - Resultados por país

Como se pode observar, com exceção da Dinamarca, Espanha, Noruega e Suécia, todos os restantes países apresentam um R2 superior no período 2005- 2012, o que sugere que a relevância da informação contabilística melhorou com a adoção dasIFRS.

Estes resultados são na sua generalidade consistentes com os obtidos em estudos anteriores. Concretamente, o caso de Espanha, estes resultados vão ao encontro dos obtidos por Callao et al. (2007) que concluíram que a associação entre os valores de mercado e os valores contabilísticos é inferior depois da adoção das IFRS nas empresas espanholas. No caso de Portugal, estes resultados são consistentes com os obtidos por Madeira (2010) que revelaram uma melhoria na relevância da informação contabilística das empresas portuguesas após a adoção das IFRS. Relativamente às empresas alemãs, os resultados deste estudo são consistentes com os obtidos por Bartov et al. (2005).

\subsection{Análise por grupos: Países Anglo-Saxónicos e PaísesContinentais}

A Tabela III apresenta os resultados dos testes estatísticos relativos ao estudo das Países Anglo-Saxónicos (Dinamarca, Reino Unido e Irlanda). 


\begin{tabular}{|c|c|c|c|c|}
\hline \multicolumn{3}{|c|}{ Período Pré-Adoção IFRS } & \multicolumn{2}{|c|}{ Período Pós-Adoção IFRS } \\
\hline Variável & Coeficiente & P-value & Coeficiente & P-value \\
\hline Constante & 3,680 & $0,000^{* * *}$ & 3,015 & $0,016^{\star *}$ \\
\hline BVPS & 0,648 & $0,000^{\star \star *}$ & 0,538 & $0,000^{\star * *}$ \\
\hline EPS & 1,757 & $0,000^{\star \star \star}$ & 4,582 & $0,000^{\star * \star}$ \\
\hline F-test & 1947,866 & $0,000^{* * *}$ & 1789,949 & $0,000^{* * *}$ \\
\hline $\mathbf{R}^{2}$ Ajustado & 0,757 & & 0,687 & \\
\hline \multicolumn{2}{|c|}{$P$-value do T-test (Igualdade de médias) } & 0,3879 & & \\
\hline
\end{tabular}

Tabela III - Resultados para o grupo de países Anglo-Saxónicos

*** $,{ }^{* *},{ }^{*}$ representam nível de significância a 1\%, 5\% e 10\%, respetivamente.

Em ambos os períodos os coeficientes das variáveis BVPS e EPS são positivos e estatisticamente significativos a $1 \%$. O $\mathrm{R}^{2}$ ajustado baixou no período posterior à adoção das IFRS, o que sugere uma diminuição da relevância da informação.

$\mathrm{O}$ resultado do teste estatístico $t$-student, de igualdade de médias dos $\mathrm{R} 2$ de cada país (assumindo que as variâncias são diferentes), indica que a diferença dos R2 ajustados do período antes e após a adoção das IFRS é estatisticamente significativa. Assim, pode concluir-se que dentro do grupo dos países Anglo-Saxónicos a adoção das IFRS não teve um impacto favorável na relevância da informação contabilística. Uma possível justificação para este resultado pode ser o facto de a estrutura das IFRS ter uma forte influência Anglo-Saxónica, e como tal o mercado não reconhecer valor adicional ao uso do normativo internacional. Daske et al. (2009) concluíram que as consequências económicas da adoção obrigatória das IFRS na Europa foram maiores em países onde as diferenças entre as normas nacionais e as IFRS eram maisevidentes.

Os resultados das regressões para as empresas dos países Continentais são apresentados na Tabela IV.

\begin{tabular}{|c|c|c|c|c|}
\hline \multicolumn{3}{|c|}{ Período Pré-Adoção IFRS } & \multicolumn{2}{|c|}{ Período Pós-Adoção IFRS } \\
\hline Variável & Coeficiente & $P$-value & Coeficiente & $P$-value \\
\hline Constante & 0,493 & 0,802 & 0,949 & 0,632 \\
\hline BVPS & 0,539 & $0,000^{\star \star \star}$ & 0,684 & $0,000^{\star * \star}$ \\
\hline EPS & 2,987 & $0,000^{* * *}$ & 2,972 & $0,000^{\star * *}$ \\
\hline F-test & 536,367 & $0,000^{\star \star \star}$ & 888,947 & $0,000^{\star \star \star}$ \\
\hline $\mathbf{R}^{2}$ Ajustado & 0,567 & & 0,615 & \\
\hline \multicolumn{3}{|c|}{$P$-value do $T$-test (lqualdade de médias) } & & \\
\hline
\end{tabular}

Tabela IV - Resultados para o grupo de paísesContinentais

***, **, * representam nível de significância a 1\%,5\% e 10\%,respetivamente. 
Como se pode observar, os coeficientes das variáveis BVPS e EPS são positivos e estatisticamente significativos a $1 \%$ para ambos os períodos. $\mathrm{O} \mathrm{R}^{2}$ ajustado para o grupo dos países Continentais aumenta de $56,7 \%$ para $61,5 \%$, o que sugere um acréscimo na relevância da informação contabilística nas empresas destespaíses.

O resultado do teste estatístico t-student, de igualdade de médias dos $\mathrm{R} 2$ de cada país que compõem o grupo Continental (assumindo que as variâncias são diferentes), indica que a diferença dos R2 ajustados é estatisticamente significativa. Assim, pode concluirse que, dentro do grupo dos países Continentais, houve um aumento da relevância da informação contabilística após a adoção dasIFRS.

\subsection{Análise comparativa dos países Anglo-Saxónicos e países Continentais}

A Tabela $V$ sumariza e compara os resultados obtidos nas análises anteriores e apresenta o resultado do teste estatístico de igualdade de médias dos R2 ajustados individuais de cada país da amostra (assumindo que as variâncias são diferentes).

\begin{tabular}{|l|c|c|}
\hline \multirow{2}{*}{ Países Anglo-Saxónicos } & $\begin{array}{c}\text { Período Pré- } \\
\text { Adoção IFRS }\end{array}$ & $\begin{array}{c}\text { Período Pós- } \\
\text { Adoção IFRS }\end{array}$ \\
\cline { 2 - 3 } Países Continentais & $75,7 \%$ & $68,7 \%$ \\
P-value do T-test (Igualdade de médias ) & $56,7 \%$ & $61,5 \%$ \\
\hline
\end{tabular}

Tabela V - Resultados por grupo de países

Como se pode observar, em ambos os períodos, os R2 dos países Anglo- Saxónicos são superiores ao dos países Continentais, sugerindo que a relevância da informação contabilística é superior nas empresas dos países Anglo-Saxónicos. O p-value dos testes de igualdade de médias realizados para ambos os períodos comprova que a diferença dos R2 do modelo Anglo- Saxónico para o modelo Continental é estatisticamente significativa. Desta forma, pode concluir-se que as empresas dos países Anglo-Saxónicos apresentam maior relevância da informação contabilística que as empresas dos países Continentais antes e após a adoção das IFRS.

Estes resultados vão ao encontro das conclusões dos estudos anteriores que sugerem que a relevância da informação contabilística é superior nos países Anglo-Saxónicos (Alford et al, 1993; Ali \& Hwang, 2000; Ball et al, 2001; Narktabtee \& Patpanichchot, 2011). 


\section{I CONCLUSÃO}

Neste estudo analisou-se o impacto da adoção obrigatória das IFRS na relevância da informação contabilística de empresas da Europa, comparando posteriormente o impacto verificado entre os países Anglo-Saxónicos e os países Continentais. Para tal, utilizouse a metodologia seguida por Barth et al. (2005) e uma amostra composta por 1640 empresas cotadas de 14 países da Europa, sendo o período amostral de 1999 a 2012.

Os resultados obtidos sugerem que com a adoção das IFRS há uma melhoria da relevância da informação contabilística nas empresas dos seguintes países: Portugal, França, Alemanha, Bélgica, Finlândia, Grécia, Áustria, Holanda, Reino Unido e Irlanda. No entanto, para as empresas dos restantes países da amostra, Noruega, Suécia, Espanha e Dinamarca, esta melhoria não se verifica, havendo uma diminuição na relevância da informaçãocontabilística.

Analisando o grupo dos países Anglo-Saxónicos no seu conjunto, os resultados revelam que com a adoção obrigatória das IFRS a relevância da informação contabilística diminuiu. Uma possível justificação para este resultado pode ser o facto de a estrutura das IFRS ter uma forte influência Anglo-Saxónica, sendo que por isso o impacto nestes países possa não ser tão significativo. Já no grupo dos países Continentais registou-se um aumento da relevância da informação contabilística após a adoção as IFRS, sugerindo que o mercado reconhece que a informação contabilista produzida segundo o normativo internacional é mais relevante e, consequentemente de maiorqualidade.

Por fim, os resultados sugerem que apesar da diminuição referida anteriormente nas empresas dos países Anglo-Saxónicos após a adoção das IFRS, estes países apresentam maior relevância da informação contabilística face aos Continentais em ambos os períodos analisados. Este resultado corrobora resultados de estudos anteriores que evidenciam que as empresas dos países Anglo-Saxónicos têm maior relevância contabilística que os Continentais (Alford et al., 1993; Ali \& Hwang, 2000; Ball et al., 2001; Narktabtee \& Patpanichchot,2011).

Este estudo contribui para a literatura sobre a relevância da informação contabilística em geral, e mais especificamente para a que analisa o impacto da adoção obrigatória das IFRS na relevância da informação contabilística na Europa, por vários motivos. Primeiro, é utilizado um horizonte temporal bastante alongado. Especificamente, é analisado um período pós-adoção das IFRS mais longo do que em estudos anteriores, o que permite uma melhor análise do efeito da adoção das IFRS. Segundo, usa uma amostra internacional, ao contrário da maioria dos estudos anteriores que se focam na realidade de um único pais, permitindo uma análise direta entre países, uma vez que estuda vários países no mesmo período temporal. Terceiro, ao analisar os resultados por grupos de países com caraterísticas semelhantes é possível perceber que fatores influenciam a relevância da informação. A adoção das IFRS só por si pode não conduzir a uma melhoria da qualidade 
da informação pois existem outros fatores como os culturais, legais, institucionais, políticos que podem influenciar a qualidade do relato financeiro e o seu reconhecimento por parte do mercado financeiro.

\section{REFERÊNCIAS}

Amir E., HarrisT. e Venuti E. (1993). A comparison of the value-relevance of US versus non-US GAAP accounting measures using form 20F reconciliations. Journal of Accounting Research 31,230-264.

Alford A., Jones J., Leftwich, R. e Zmijewski, M. (1993). The relative informativeness of accounting disclosure in different countries. Journal of Accounting Research 31, 183-223.

Ali A., e Hwang, L. (2000). Country-specific Factors Related to Financial Reporting and the Value Relevance of Accounting Data. Journal of Accounting Research 38, (1), 1-22.

Ball R., Kothari S. P. e Robin A. (2001). The Effect of International Institutional Factors on Properties of Accounting Earnings. Journal of Accounting and Economics 29 (1),1-51.

Ball R., Robin A. e Wu J.S. (2003). Incentives versus Standards: Properties of Accounting Income in Four East Asian Countries. Journal of Accounting and Economics 36 (1-3), 235-270.

Barth M., Beaver W. e Landsman W. (2001). The relevance of the value relevance literature for financial accounting standard setting: Another view. Journal of Accounting \& Economics 31 (1-3), 77-104.

Barth M., Landsman W. e Lang M. (2005). International accounting standards and accounting quality. Journal of Accounting Research 46 (3), 467-498.

Bartov E., Goldberg S. R. e Kim M. (2005). Comparative value relevance among German, US and International Accounting Standards: A German stock market perspective. Journal of Accounting Auditing \& Finance 20(2), $95-119$.

Callao S., Jarne J. e Laínez J. (2007). Adoption of IFRS in Spain: effect on the comparability and relevance of financial reporting. Journal of Accounting, Auditing and Taxation 16 (2), 148-178.

Christensen H., Lee E. e Walker M. (2015). Incentives or Standards: What Determines Accounting Quality Changes around IFRS Adoption?. European Accounting Review, 24(1), 31-61.

Daske,H., Hail, L., Leuz, C., and Verdi, R., 2009. Mandatory IFRS reporting around the world: early evidence on the economic consequences. Journal of Accounting Research, 46(5), 973-1321.

Devalle A., Onali E. e Magarini R. (2010). Assessing the value relevance of accounting data after the introduction of IFRS in Europe. Journal of International Financial Management and Accounting 21 (2), 85-119.

Fontes A., Rodrigues L. L. e Craig R. (2005). Measuring the Convergence of National Accounting Standards with International Financial Reporting Standards. Accounting Forum 29 (4),415-436.

Glaum, M., Street, D., \& Vogel, S. (2007). Compliance with IFRS Disclosures by European Companies: The Role of Country Effects and Other Determinants. Working paper, European Accounting Association 31th Annual Congress: Rotterdam.

Hung M. (2000). Accounting Standards and Value Relevance of Earnings: An International Analysis. Journal of Accounting and Economics 30 (3), 401-420. 
Hung M. e Subramanyam K.R. (2004). Financial Statement Effects of Adopting International Accounting Standards: The case of German. Review of Accounting Studies 12 (4), 623-657.

Jeanjean T. e Stolowy H. (2008). Do accounting standards matter? An exploratory analysis of earnings management before and after IFRS adoption. Journal of Accounting and Public Policy 27 (6), 480-494.

La Porta R., Lopez-de-Silanes F., Shleifer A. e Vishny R. (2002). Investor Protection and Corporate Valuation. The Journal of Finance 57 (3), 1147-1170.

Lang M., Raedy J. e M. Yetman. (2003). How Representative are Firms that are Cross Listed in the United States? An Analysis of Accounting Quality. Journal of Accounting Research 41 (2),363-386.

Leuz C., Nanda D. e Wysocki P. (2003). Earnings management and investor protection: an international comparison. Journal of Financial Economics 69 (3), 505-527.

Madeira J. (2010). Relevância da Informação Financeira Antes e Após o Subprime. Dissertação de Mestrado em Gestão, Instituto Universitário de Lisboa - ISCTE BusinessSchool.

Morais A. e Curto J. (2008). Accounting quality and the adoption of IASB standards - Portuguese evidence. Revista Contabilidade \& Finanças 19 (48), 103-111.

Narktabtee K. e Patpanichchot S. (2011). Investor Protection, Deviation of Local Accounting Standards From IFRS, and the effectiveness of the IFRS Adoption. Journal of Modern Accounting and Auditing 7 (12), 13291343.

Nobes C. (1998). Towards a General Model of the Reasons for International Differences in Financial Reporting. Abacus - Journal of Accounting, Finance and Business Studies 34 (2),162-187.

Nobes C. e Parker R. (1998). Comparative International Accounting. $5^{\mathrm{a}}$ Ed. Harlow: Prentice Hall Europe.

Paananen M., e Lin H. (2009). The development of accounting quality of IAS and IFRS over time: The case of Germany. Journal of International Accounting Research 8 (1), 31-55.

Schiebel, H. A. (2007). Empirical value relevance of German GAAP and IFRS. Journal of economic and financial sciences, 1(2), 141-170. 


\section{ESTUDO COMPARATIVO ENTRE O ENSINO DA CONTABILIDADE PRESENCIAL E A DISTÂNCIA NO \\ PARAGUAI}

Data de aceite: $24 / 07 / 2020$

Data de Submissão: 01/05/2020

Elisiane Alves Fernandes Universidad Evangélica del Paraguay. Asunción -

Paraguay

Lattes: http://lattes.cnpq.br/4796286598372455

Dego Hernán Fleitas Recalde Universidad Nacional de Asunción - Paraguay

Conacyt: https://cv.conacyt.gov.py/publicar/ cv?id=adcd15206818547362b8e4c1926da81b

RESUMO: Um estudo comparativo tem objetivo de analisar dois ou mais serviços e práticas, sendo uma forma de conhecer e analisar suas semelhanças e diferenças. Um bom estudo comparativo permite: identificar e analisar as melhores práticas; aprendizagem e desenvolvimento; formular recomendações; idealizando o aperfeiçoamento de práticas e mudanças organizacionais. A comparação entre o estudo da contabilidade presencial e a distância no Paraguai tem o objetivo de conhecer, identificar e analisar as principais diferenças e semelhanças e apontar as dificuldades que os alunos do ensino a distância enfrentam nas disciplinas práticas principalmente com a falta de interação entre professores e alunos. Esse estudo apontará as semelhanças e as diferenças entre as grades curriculares na mesma instituição privada que oferece as duas modalidades de ensino e também a comparação da grade curricular do curso de Contabilidade de uma instituição de ensino superior privada e de uma instituição pública, com o intuito de demonstrar que as modalidades são diferentes, mas o ensino e o exercício da profissão podem ser equivalentes.

PALAVRAS-CHAVE: Contabilidade. Ensino Superior. Ensino Presencial. Ensino a Distância.

\section{COMPARATIVE STUDY IN PARAGUAY \\ BETWEEN THE TEACHING OF \\ ACCOUNTING IN CLASSROOM AND \\ DISTANCE}

ABSTRACT: A comparative study has as an objective to analyze two or more services and practices, been a form to know and analyze their similarities and differences. A good comparative study permits: identify and analyze the better practices, knowledgement and development; formulating recommendations, idealizing and improving the practices and organizational changes. The comparison between the study of accounting in a classroom and distance in Paraguay has the objective to know, identify, and analyze the main differences and similarities and to appoint the difficulties that the students of a distance learning may have in the practical 
courses primarily with the lack of interaction between professor and student. This study will show the similarities and the differences between the academic credits in the same private institution that offers the two ways of study and also the comparison of the academic credits of the Accounting Course in a private undergraduate institution and a public institution, with the intent do demonstrate that they are different but the teaching and the exercise of the profession may be equivalent.

KEYWORDS: Accounting, Undergraduate. Classroom study. Distance study.

\section{I INTRODUÇÃO}

A contabilidade é uma ferramenta fundamental porque fornece informações úteis, oportunas e precisas sobre a situação financeira de empresas e instituições. Com o passar do tempo, a evolução da tecnologia e a complexidade das operações financeiras, o Contador Público foi forçado a manter um constante desenvolvimento de seu conhecimento acadêmico e tornou-se necessário obter a maior experiência possível.

Por ser um curso extremamente prático questiona-se sobre o ensino a distância como uma forma de aprendizado. Essa inquietude gerou um problema de investigação é possível aprender contabilidade à distância?

\section{I REFERENCIAL TEÓRICO}

No referencial teórico apresenta-se a História da Contabilidade, a Contabilidade no Paraguai, o Ensino Superior no Paraguai, Legislação do Ensino a Distância no Paraguai, a Caracterização e Mensalidades do Curso Presencial e a Distância, Outras Instituições que Oferecem o Curso de Contabilidade a Distância e Presencial.

\subsection{HISTÓRIA DA CONTABILIDADE}

Não há como determinar exatamente como surgiu à contabilidade, mas ao fazer uma relação com a humanidade, percebe-se que a contabilidade é tão antiga quanto à própria humanidade.

Para Augusto (2009) a história da Contabilidade surge com o desenvolvimento da sociedade.

O surgimento e a evolução da contabilidade confundem-se com o próprio desenvolvimento da humanidade. Nesse contexto os estudos sobre as civilizações da Antiguidade nos mostram que o homem primitivo já "cuidava da sua riqueza", através, por exemplo, da contagem e do controle do seu rebanho.

Porém, alguns estudiosos fazem remontar os primeiros sinas objetivo da existência das contas e os primeiros exemplos completos da contabilidade, mesmo sendo uma forma 
de contabilidade rudimentar, a aproximadamente 4000 anos a.C na civilização sumériobabilonense.

A contabilidade aprimorou-se de acordo com as necessidades de cada período histórico. O aparecimento da escrita, o surgimento da moeda, a prensa de Gutemberg, o descobrimento da América, a invenção da máquina a vapor, que deu impulso à Revolução Industrial, são marcos da nossa história que fizeram desencadear o desenvolvimento da ciência contábil. (AUGUSTO, 2009).

A partir de Luca Pacioli muitas publicações surgiram sobre evolução do pensamento contábil. Augusto (2009) continua afirmando que:

O desenvolvimento da contabilidade em toda a sua história esteve intimamente ligada ao desenvolvimento econômico e as transformações sociopolíticas e socioculturais experimentadas em cada época. O homem foi sentindo a necessidade de aperfeiçoar seu instrumento de avaliação da situação patrimonial ao mesmo tempo em que as atividades econômicas foram-se tornando mais complexas.

Podemos delimitar a evolução histórica da contabilidade em duas grandes escolas: a italiana e a norte-americana.

A partir do século XII até o inicio do XVII, a Europa e, mais particularmente, a Itália "explodiram" em desenvolvimento econômico e cultural, trazido pela grande expansão comercial. Concomitantemente, verificou-se nesse período soberbo desenvolvimento da contabilidade na Europa.

Existem inúmeras definições encontradas na literatura, pode-se considerar que a contabilidade é uma ciência que estuda e controla o patrimônio. Portanto, o seu objeto principal é o patrimônio.

\subsection{A CONTABILIDADE NO PARAGUAI}

A profissão de contador no Paraguai está amparada na Lei $n^{\circ} 371$, de 6 de dezembro de 1972, dentre outras coisas prevê funções em entidades públicas e privadas, algumas como a organização e abordagem contábil; o estudo de viabilidade; análise e certificação de demonstrações financeiras; e) contabilidade; assessoria em matéria tributária; interpretação de balanços; avaliação de bens econômicos e auditoria contábil;

Para Silva, Madeira \& Assis (2004, p.9) a lei é incapaz de habilitar e qualificar a profissão contábil, pois não atribuem as capacidades, aptidões e habilidades exclusivamente para os contadores e não prevê a criação de um conselho que fiscalize a atuação profissional e não estabelece sanções ao exercício legal da profissão.

Para exercer a profissão de contador não existe a obrigatoriedade de estar vinculado a um conselho. Mesmo assim existem o Colégio de Contadores del Paraguay que foi fundado em 09 de junho de 1916 e o Consejo de Contadores Públicos del Paraguay que 
foi fundado em 10 de março de 2005. O profissional contador também pode solicitar uma licença para a Municipalidad de Asunción que para assinar os balanços é imprescindível.

De acordo com Beuren \& Brandão (2001, p. 56) o mundo globalizado fez com que os países percebessem a necessidade de adotar as normas internacionais do IASB (International Accounting Standards Board).

No Paraguai as normas do processo de contabilidade são baseadas na legislação sendo as principais delas: a Lei do Comerciante, a Legislação Bancária, a Legislação das Seguradoras, a Lei do Mercado de Capitais, a Legislação Fiscal e a do Importo de Renda, além de seguir as normas da Comissão Nacional de Valores e as do Colégio de Contadores do Paraguai (Beuren \& Brandão, 2001, p. 48).

As normas contábeis são regulamentadas por leis aprovadas pelo Ministério e la Hacienda - Subsecretaria de Estado de Tributación - Dirección General de Contabilidad Pública.

O Ministério da Fazenda do Paraguai possui um Departamento de Normas e Técnicas de Contabilidade que é a área responsável por estabelecer as regras e procedimentos para solicitar o registro contábil das operações econômico-financeiras da Agência e Entidades Estaduais, em virtude das disposições da Lei n 1535/99 Da Administração Financeira do Estado e uma das suas principais funções é Estabelecer o Marco Regulatório do Sistema Contábil do Setor Público, de acordo com os princípios contábeis geralmente aceitos e as Normas Internacionais de Contabilidade do Setor Público.

\subsection{O ENSINO SUPERIOR NO PARAGUAI}

A primeira universidade de ensino superior do Paraguai foi a Universidade Nacional de Assunção - UNA, que depois de inúmeras tentativas que datam da era colonial, foi fundada em 24 de setembro de 1889.

O projeto foi aprovado durante o governo do presidente constitucional Patricio Escobar, pela persistência do congresso ou parlamento nacional. Esta lei estabeleceu a constituição de três faculdades, sendo elas: Direito e Ciências Sociais, Medicina e Matemática.

A UNA foi à única instituição universitária no Paraguai até 1960, quando foi fundada a Universidade Católica Nuestra Señora de la Asunción.

O país possui atualmente 6 (seis) instituições públicas e 54 (cinquenta e quatro) privadas para o ensino presencial e 1 (uma) instituição pública e 7 (sete) privadas para o ensino a distância para uma população de 6.725 milhões de habitantes, de acordo com o Banco Mundial em 2016. 


\subsection{LEGISLAÇÃO DO ENSINO A DISTÂNCIA NO PARAGUAI}

Na Lei n 4995 de 26 de junho de 2013 a Educação a Distância ou Educação Não Presencial é tratada na Seção IV e de acordo com o artigo 69 a Educação à distância ou não Presencial é aquela cuja metodologia educacional é caracterizada pelo uso de ambientes de aprendizagem em que são utilizados muitos meios de informação e de comunicação e mediações pedagógicas que permitem criar uma dinâmica de interações orientadas para a aprendizagem autônoma e aberta, superar o ensino por exposição e aprendizagem por recepção, bem como barreiras espaços-temporais e as limitações da realidade objetiva através de simulações virtuais; relações antecipadas reais ou mediadas e facilitar a aprendizagem pela investigação e através da colaboração de vários agentes educativos.

O artigo 70 da mesma lei determina que as instituições que podem oferecer a educação à distância devem ser legalmente qualificadas, devem possui infraestrutura, equipamentos e professores treinados especificamente para esta metodologia educacional, bem como os seus respectivos programas e sistemas de avaliação de cursos e disciplinas, aprovados pelas autoridades competentes. Neste artigo a lei também prevê a regulamentação do ensino a distância pelo Conselho Nacional de Educação Superior.

A regulamentação foi publicada pelo Conselho Nacional de Educação - CONES através da resolução 63 de 2016. O documento é composto das normas do ensino a distância no Paraguai.

\subsection{CARACTERIZAÇÃO}

Como comparação escolheu-se analisar a Grade Curricular da Universidad Autónoma de Asunción e da Universidad Columbia que oferecem o curso de Contabilidade Pública presencial e a distância e da Universidad Nacional de Asunción que é pública e somente presencial, porém considerada como informação relevante para o estudo, uma vez que é a melhor universidade do país, ainda que o Paraguai nem apareça no QS University Ranking que avalia as universidades mundiais e publica as 950 melhores. Em uma busca na internet o site Ranking Web de Universidades aponta a Universidade Nacional de Asunción na melhor posição do país com a classificação de 2.653 , tendo a segunda colocada a Universidad Del Norte Paraguay que ocupa a posição 4.691.

A Universidad Autónoma de Asunción oferece o curso de Contabilidade Pública nas modalidades presencial e a distância e a grade curricular é a mesma, a carga-horária total do curso é integralizada com 2.880 horas/relógio, em no mínimo 5 (cinco) anos. O título é de Contador Público.

No site da universidade verificam-se informações sobre o curso e sobre o perfil do profissional de Contabilidade Pública onde constam visão, missão, valores, objetivos, perfil 
do egresso, campo de trabalho e as capacidades dos profissionais que são resumidas em: Contador Geral de empresas e instituições dos diferentes setores do mercado; Auditor interno e externo nas áreas financeira, tributária, governamental e operacional; Analista Financeiro e Administrativo, Assessor e Consultor em questões financeiras tributárias e trabalhistas; Profissional apto a planejar, organizar, liderar e avaliar transações econômicas e financeiras do setor público e privado.

A Universidad Columbia também oferece o curso de Contabilidade Pública nas modalidades presencial e a distância, a grade curricular é a mesma para ambas as modalidades, grade curricular é a mesma e a carga-horária total de 3.264 horas/relógio, integralizada em no mínimo 5 (cinco) anos. O título é de Contador Público.

Dentre as informações disponíveis no site da internet pode-se destacar o objetivo do curso que é formar profissionais com conhecimentos sólidos, capazes de atuar nas áreas tributária, contábil, auditoria, financeira e orçamentária em empresas privadas, entidades públicas e organizações não governamentais, bem como de forma independente, prestando serviços de consultoria, atuando desde o início do desempenho de sua profissão de acordo com as Normas Internacionais e Nacionais de Contabilidade, Informações Financeiras e Auditoria.

A Universidad Nacional de Asunción é pública e oferece o curso de Contabilidade Pública somente na modalidade presencial e grade curricular e carga-horária totaliza 3.612 horas/relógio, integralizada em no mínimo 5 (cinco) anos. O título é de Contador Público.

O curso de Contador Público é equivalente ao Bacharel em Ciências Contábeis formado no Brasil.

\begin{tabular}{|c|c|c|}
\hline UNA & UAA & COLUMBIA \\
\hline $\begin{array}{l}\text { Administración de las Personas o } \\
\text { Administración Pública }\end{array}$ & $\begin{array}{l}\text { Administración de Recursos } \\
\text { Humanos }\end{array}$ & Gestión del Talento Humano \\
\hline Administracion Presupuestaria & Administracion General & $\begin{array}{l}\text { Presupuesto y Control } \\
\text { Presupuestario }\end{array}$ \\
\hline Auditoria en Informatica & Auditoria Informática & $\begin{array}{l}\text { Auditoría Informática y } \\
\text { Gubernamental }\end{array}$ \\
\hline Auditoria Gubernamental & Auditoria Gubernamental & \\
\hline Auditoria I & Auditoria & \\
\hline Auditoria II & Auditoria de Gestión & $\begin{array}{l}\text { Auditoría de Gestión } \\
\text { Administrativa }\end{array}$ \\
\hline $\begin{array}{l}\text { Auditoria III (Ambiental Y } \\
\text { Forense) }\end{array}$ & Auditoria Forense & Auditoría Ambiental Forense \\
\hline Contabilidad de Gestion I & Contabilidade de Gestión & \\
\hline Contabilidad de Gestion II & $\begin{array}{l}\text { Contabilidad de Gestión } \\
\text { Intermedia }\end{array}$ & \\
\hline Contabilidad Financiera I & Contabilidade Financiera & Contabilidad Financiera \\
\hline Contabilidad Financiera II & $\begin{array}{l}\text { Contabilidade Financiera } \\
\text { Intermedia I }\end{array}$ & Contabilidad Financiera \\
\hline
\end{tabular}




\begin{tabular}{|c|c|c|}
\hline Contabilidad Financiera III & $\begin{array}{l}\text { Contabilidade Financiera } \\
\text { Intermedia II }\end{array}$ & Contabilidad Financiera 3 \\
\hline Contabilidad Financiera IV & $\begin{array}{l}\text { Contabilidade Financiera } \\
\text { Avanzada }\end{array}$ & \\
\hline $\begin{array}{l}\text { Contabilidad Financiera V } \\
\text { (Seguros Y Cooperativas) }\end{array}$ & $\begin{array}{l}\text { Contabilidad de Empresas } \\
\text { Financieras y de Seguros }\end{array}$ & \\
\hline $\begin{array}{l}\text { Contabilidad Financiera VI } \\
\text { (Bancos) }\end{array}$ & & Gestión Bancaria Y Financiera \\
\hline Contabilidad Gubernamental & $\begin{array}{l}\text { Contabilidad Pública yY del } \\
\text { Estado }\end{array}$ & Contabilidad Gubernamental \\
\hline $\begin{array}{l}\text { Convocacion de Acreedores } \mathrm{Y} \\
\text { Quiebra }\end{array}$ & $\begin{array}{l}\text { Convocación de Acreeddores y } \\
\text { Quiebras }\end{array}$ & Ley de Quiebra \\
\hline Derecho del Trabajo & Legislación Laboral & Derecho Laboral \\
\hline Derecho Privado & & Derecho Civil y Comercial \\
\hline $\begin{array}{l}\text { Diseño de Sistemas de } \\
\text { Información }\end{array}$ & Diseño de Sistemas Contables & $\begin{array}{l}\text { Diseño de Sistemas de } \\
\text { Información }\end{array}$ \\
\hline Emprendedorismo I & Desarollo de Empreendedores & Emprendedurismo \\
\hline Estadistica & $\begin{array}{l}\text { Estadística Descriptiva E } \\
\text { Inferencial }\end{array}$ & Estadística \\
\hline Ética & Ética en los Negócios & Ética y Responsabilidad Social \\
\hline Finanzas de Empresas & Finanzas Gerenciales & Finanzas Empresariales \\
\hline Gabinete I & Gabinete de Contabilidad & Gabinete Contable \\
\hline Gabinete II & & Gabinete Proyecto Contable \\
\hline Informatica Aplicada & Suficiencia em Informática & Informática Aplicada \\
\hline Ingles I & Inglês para Negócios I & Inglés 1 \\
\hline UNA & UAA & COLUMBIA \\
\hline Ingles II & Suficiencia en Idioma Inglês & Inglés 2 \\
\hline Macroeconomia & & Macroeconomía \\
\hline Matematica I & Matemática Aplicada & Matemáticas \\
\hline Matematica II & Matemática Financiera & \\
\hline $\begin{array}{l}\text { Mercado de Capitales o Comércio } \\
\text { Internacional }\end{array}$ & Mercado de Capitales & Mercado de Capitales \\
\hline Mercadotecnia & Marketing & Mercadotecnia \\
\hline $\begin{array}{l}\text { Metodologia y Tecnica de } \\
\text { Investigacion }\end{array}$ & $\begin{array}{l}\text { Metodologia de la Investigación } \\
\text { Social }\end{array}$ & $\begin{array}{l}\text { Metodología de la } \\
\text { Investigación }\end{array}$ \\
\hline Microeconomia & Introduccion a la Economia & Microeconomía \\
\hline Pasantía Supervisionada & Prática Asistida & \\
\hline Regimen Legal de las Empresas & & Régimen Fiscal de la Empresa \\
\hline $\begin{array}{l}\text { Relaciones Humanas y } \\
\text { Comunicacion }\end{array}$ & & $\begin{array}{l}\text { Relaciones Públicas y } \\
\text { Humanas }\end{array}$ \\
\hline Sociologia & Sociologia Empresarial & Sociología \\
\hline $\begin{array}{l}\text { Tecnologia de la Información y de } \\
\text { la Comunicación }\end{array}$ & $\begin{array}{l}\text { Introduccíon a las Tecnologías } \\
\text { de Información }\end{array}$ & $\begin{array}{l}\text { Tecnología de la Información y } \\
\text { Comunicación }\end{array}$ \\
\hline Teoria de la Administracion & $\begin{array}{l}\text { Teoria General de la } \\
\text { Administracion }\end{array}$ & $\begin{array}{l}\text { Administración I - } \\
\text { Fundamentos de la } \\
\text { Administración }\end{array}$ \\
\hline Trabajo Final de Grado & Trabajo de Grado & \\
\hline Tributacion I & Tributación de Empresas & Tributación 1 \\
\hline \multirow[t]{3}{*}{ Tributacion II } & $\begin{array}{l}\text { Impuesto a la Renta: Empresas } \\
\text { y Personas }\end{array}$ & Tributación 2 \\
\hline & Auditoria Tributaria & $\begin{array}{l}\text { Auditoría Contable } \\
\text { Operacional }\end{array}$ \\
\hline & Comunicación: Oral y Escrita & Comunicación Escrita y Oral \\
\hline
\end{tabular}




\begin{tabular}{|l|l|l|}
\hline Emprendedorismo II & $\begin{array}{l}\text { Procesos y Fundamentos de } \\
\text { Gestión de Empresas }\end{array}$ & $\begin{array}{l}\text { Formulación y Evaluación de } \\
\text { Proyectos de Inversión }\end{array}$ \\
\hline $\begin{array}{l}\text { Organizacion, Sistemas y } \\
\text { Metodos I y II }\end{array}$ & $\begin{array}{l}\text { Diseño Organizacional y de } \\
\text { Procesos }\end{array}$ & $\begin{array}{l}\text { Diseño y Estructura } \\
\text { Organizacional }\end{array}$ \\
\hline
\end{tabular}

Quadro 1: Quadro Comparativo da Grade Curricular

Fonte: elaborado pelos autores

As grades curriculares analisadas são muito semelhantes. A Universidad Nacional de Asunción possui 54 disciplinas na grade curricular do curso, das quais 35 são equivalentes com a Universidad Autónoma de Asunción e 36 são equivalentes com a Universidad Columbia. Entre a Universidad Autónoma de Asunción e a Universidad Columbia são 30 equivalentes. As disciplinas específicas são quase todas equivalentes para o bom exercício da profissão após a conclusão do curso, inclusive por exigência do mercado e da própria legislação do ensino da contabilidade.

\subsection{MENSALIDADES DO CURSO PRESENCIAL E A DISTÂNCIA}

As mensalidades do curso a distância são mais acessíveis que as do curso presencial, conforme podemos avaliar na tabela abaixo:

\begin{tabular}{|c|c|r|r|r|}
\hline \multicolumn{4}{|c|}{ MENSALIDADES } \\
\hline UNA & \multicolumn{2}{|c|}{ UAA } & \multicolumn{2}{c|}{ COLUMBIA } \\
\hline Presencial & Presencial & \multicolumn{1}{|c|}{ Distancia } & Presencial & \multicolumn{1}{c|}{ Distancia } \\
\hline Gratuito* & ${ }^{* *}$ & ${ }^{* * *} \mathrm{Gs} 530.000$ & Gs 540.000 & Gs390.000 \\
\hline Gratuito* & ${ }^{* *}$ & $\mathrm{R} \$ 378,00$ & $\mathrm{R} \$ 385,00$ & $\mathrm{R} \$ 279,00$ \\
\hline
\end{tabular}

Quadro 2: Quadro Comparativo das Mensalidades do Curso a Distância e Presencial Fonte: elaborado pelos autores

\subsection{OUTRAS INSTITUIÇÕES QUE OFERECEM O CURSO DE CONTABLIDADE A DISTÂNCIA}

As 8 (oito) instituições de ensino a distância atualmente no Paraguai também oferecem os cursos presenciais. O curso de Contabilidade é oferecido a distância e presencialmente pela Universidad Autónoma de Assunción (UAA), pela Universidad Politécnica y Artística del Paraguay (UPAP) e pela Universidad Columbia del Paraguay. 


\section{I PROCEDIMENTOS METODOLÓGICOS}

Esse capítulo tem como objetivo a caracterização do tipo de pesquisa, os métodos e a metodologia utilizados nesta investigação.

Uma boa investigação é aquela que não deixa dúvidas sobre o uso dos métodos científicos, esclarece as relações entre as variáveis que afetam os estudos e, de igual forma, planeja com cuidado os aspectos metodológicos com a finalidade de assegurar a validade e a confiabilidade dos seus resultados, afirma Sampieri, Collado e Lucio (2010).

A pesquisa qualitativa utiliza os dados sem preocupação com a medição numérica para descobrir ou ajustar perguntas de investigação no processo de interpretação, de acordo com Sampieri, Collado e Lucio (2010). Para Bogdan e Biklen (1994) a mesma tem o ambiente natural como fonte direta dos dados e o pesquisador como instrumento chave para o êxito do estudo.

O método comparativo destina-se a interpretação dos fenômenos e propicia analisar o dado concreto, retirando desse "os elementos constantes, abstratos e gerais." (LAKATOS; MARCONI, 2007, p. 107).

Para Gil (2008) o método comparativo percorre pela investigação de indivíduos, classes, fenômenos ou fatos, com vistas a ressaltar as diferenças e as similaridades entre eles. "Sua ampla utilização nas ciências sociais deve-se ao fato de possibilitar o estudo comparativo de grandes grupamentos sociais, separados pelo espaço e pelo tempo." (GIL, 2008, p. 16-17).

Esse método consiste em explorar semelhanças e diferenças, promovendo comparações com o intuito de confirmar as semelhanças e desvendar as divergências.

Para atender aos objetivos dessa pesquisa escolhemos dentre as diferentes técnicas de coleta de dados o questionário que, de acordo com Richardson (2008), é uma entrevista estruturada e desempenha duas funções: descrever as características e medir determinadas variáveis de um grupo social. Os dados coletados por meio do questionário possibilitam analisar as características de um individuo ou de um grupo de sujeitos.

Não se encontrou número oficial de profissionais de contabilidade no Paraguai, como o país não conta com um conselho de regulamentação da profissão essa informação é desconhecida, por esse motivo a amostra utilizada é a por acessibilidade que de acordo com GIL (2008) essa amostragem é a menos rigorosa de todos os tipos de amostragem.

\footnotetext{
Por isso mesmo é destituída de qualquer rigor estatístico. O pesquisador seleciona os elementos a que tem acesso, admitindo que estes possam de alguma forma, representar o universo. Aplica-se este tipo de amostragem em estudos exploratórios ou qualitativos, onde não é requerido elevado nível de precisão (GIL, 2008, p. 97).
}

O questionário composto de 16 questões, sendo de 01 a 03 questões pessoais e de 04 a 16 de questões específicas, foi aplicado no período de 02/10/2018 a 10/10/2018, 
na internet por meio do formulário do Google Docs enviado a 30 (trinta) profissionais da contabilidade paraguaios, eleitos por serem colegas de profissão de um dos autores através do email, destes 4 (quatro) responderam.

\section{I RESULTADOS E DISCUSSÕES}

As grades curriculares o curso de Contabilidade do ensino presencial e do ensino a distância são iguais nas instituições analisadas, portanto o aluno do ensino a distância tem a mesma estrutura curricular que os alunos do ensino presencial e com isso poderá ser considerado um egresso com as mesmas condições de exercer a profissão que um aluno do curso presencial. No Regulamento da Educação Superior a Distância e Semipresencial (CONES 2016), Título III, Artigo 31 prevê que as instituições de educação superior expedirão os respectivos títulos, certificados ou diplomas correspondentes em conformidade aos mecanismos estabelecidos para tal efeito por cada instituição. O reconhecimento e a validade outorgados aos títulos de um curso na modalidade a distancia serão os mesmos que os cursados na modalidade presencial.

\subsection{PESQUISA E RESULTADOS}

As perguntas pessoais que servem para conhecer o perfil do respondente foram conhecidas através das questões 01 a 03, sendo perguntas como idade, sexo, ano de conclusão e universidade que concluiu.

Portanto baseado nas respostas do questionário apresenta-se o perfil dos sujeitos da pesquisa que ficou assim caracterizado: Os quatro são formandos no curso de Contabilidade Pública, três são do sexo feminino e a média de idade é de 25,66 anos, dos respondentes três são da Universidade Nacional de Assunção e um da Universidade Columbia.

As questões 04 a 16 foram de caráter específico para conhecer a opinião dos profissionais da contabilidade sobre a educação à distância.

O objetivo dessa questão foi de analisar as disciplinas da grade curricular e apontar as disciplinas com maior dificuldade. 


\section{Contabilidade Financeira}

\section{Contabilidade de Gestão I}

\section{Contabilidade Governamental}

\section{Gestão II}

\section{Microeconomia}

\section{Microeconomia}

\section{Tributação II}

Figura 1: Disciplinas mais difíceis na opinião dos entrevistados

Fonte: elaborado pelos autores

De acordo com as respostas podemos avaliar que as disciplinas citadas em sua maioria são disciplinas específicas da área da contabilidade, porém a única disciplina citada mais de uma vez não é específica do curso, como não houve uma unanimidade, entendese que as disciplinas são mais fáceis ou mais difíceis de acordo com as competências e habilidades do próprio aluno.

Para Guerra (2011) o aprendizado depende de muitos fatores.

O cérebro é o órgão da aprendizagem, mas a aprendizagem não depende apenas do funcionamento cerebral. A aprendizagem requer funções mentais como atenção, memória, percepção, emoção, função executiva, entre outras. Portanto, depende do cérebro. Mas a aprendizagem depende também de outros fatores, como condições gerais de saúde, ambiente familiar, estímulos na infância, interação social, tipos de escola, aspectos culturais, políticos, socioeconômicos e muitos outros. (GUERRA, 2011, p. 3).

Essa questão solicitou que o entrevistado analisasse as grades curriculares dos cursos à distância, utilizando a experiência profissional e acadêmica e respondesse se a grade curricular é adequada para formar um bom contador. 
Resposta 1: Sim, pelo nível de exigência para o aluno que quer ser um contador é adequado.

Resposta 2: Sim porque me parece que tem todos os materiais necessários para treinar eficientemente um contador.

Resposta 3:É adequado. As disciplinas profissionais são adequadas para formar um bom contador. Porque Resposta 4: Sim. os assuntos são necessários e adequados para um conhecimento abrangente da carreira da conta.

Todos os entrevistados acreditam que as grades curriculares dos cursos a distância da UAA e da Columbia são adequados. As duas instituições utilizam as mesmas grades curriculares para as duas modalidades.

Na Resolução 63 do Consejo Nacional de Educación Superior - CONES não deixa claro que a grade curricular do ensino a distancia seja igual a do presencial, porém como o artigo 14 prevê que os alunos do ensino a distância gozarão dos mesmos benefícios dos alunos da modalidade presencial, recebendo um serviço de educação de qualidade com acesso aos recursos da tecnologia, da informação e da comunicação e ter acesso a equipamentos e materiais adequados aos requerimentos da aprendizagem mediada, presume-se que as disciplinas oferecidas devem ser as mesmas.

A questão indagou quais seriam as disciplinas que o aluno do ensino a distância teria dificuldades de aprendizado para conclusão do curso de Contabilidade Pública.

Resposta 1:Os assuntos práticos que têm um passo a passo para serem resolvidos.

Resposta 2: Eu acho que poderia ser o Gabinete I e II.

Resposta 3: As práticas e as disciplinas que necessitam uma troca de experiências instantânea, como por exemplo, Contabilidade de Custos, Contabilidade Financeira, Formulação de Projetos de Investimentos, Contabilidade de Bancos, Gabinete de Contabilidade e Economia.

Resposta 4:Contabilidade de Custos - Contabilidade Financeira - Finanças.

Os respondentes acreditam que algumas disciplinas específicas do curso de contabilidade que exigiriam à prática, a intervenção do professor, a troca de experiência e explicações simultâneas poderiam causar mais dificuldades entre os alunos a distância.

A legislação da educação a distância no Paraguai é recente, de 2013 e a Regulamentação de 2016, os primeiros formandos dessa modalidade devem estar concluindo o curso em 2018 ou 2019, portanto é prematuro diagnosticar as dificuldades e os impactos da educação a distância do Curso de Contabilidade Pública no Paraguai.

Essa questão procurou saber se o respondente acredita que a grade curricular das universidades analisadas é adequada para o curso de Ciências Contábeis. 
Resposta 1: Porque há disciplinas que não são importantes para a carreira.

Resposta 2: As grades curriculares estão corretas.

Resposta 3:É adequado.

Resposta 4: Sim.

Três respondentes acreditam que as grades curriculares são adequadas e um acredita que não. A questão teve uma pergunta complementar caso a resposta fosse não for não, ela deverá ser justificada. Os que responderam sim, também justificaram.

A Lei 4995 de 2013 no artigo $6^{\circ}$ da Seção III estabelece regras para as instituições de ensino superior e as universidades e/ou faculdades buscam cumpri-las incluindo em suas grades curriculares disciplinas de formação geral.

\section{Seção III DOS OBJETIVOS DO ENSINO SUPERIOR}

Artigo $6^{\circ}$ - Os objetivos do ensino superior são: a) Formar profissionais e líderes competentes com pensamento criativo e crítico, com ética e consciência social. b) Oferecer uma educação científica, humanística e tecnológica do mais alto nível acadêmico. c) Investigar e treinar os alunos para pesquisa e pensamento teórico, contribuindo para o desenvolvimento científico, tecnológico e cultural da sociedade. d) Estender o conhecimento, serviços e cultura para a sociedade. e) Contribuir para salvaguardar e consolidar os valores que sustentam uma sociedade democrática, a pré-proteção do meio ambiente, a defesa da soberania nacional, o respeito aos direitos humanos e a busca de uma sociedade mais livre, justa e igualitária. f) Estabelecer e fortalecer relações e intercâmbios com instituições de outras nações e com organizações nacionais e internacionais. (CONES, 2016)

A questão teve o intuito de conhecer quais disciplinas de conhecimento geral, ou seja, aquelas que não específicas do curso, não seriam necessárias no currículo do curso de Ciências Contábeis na visão dos entrevistados.

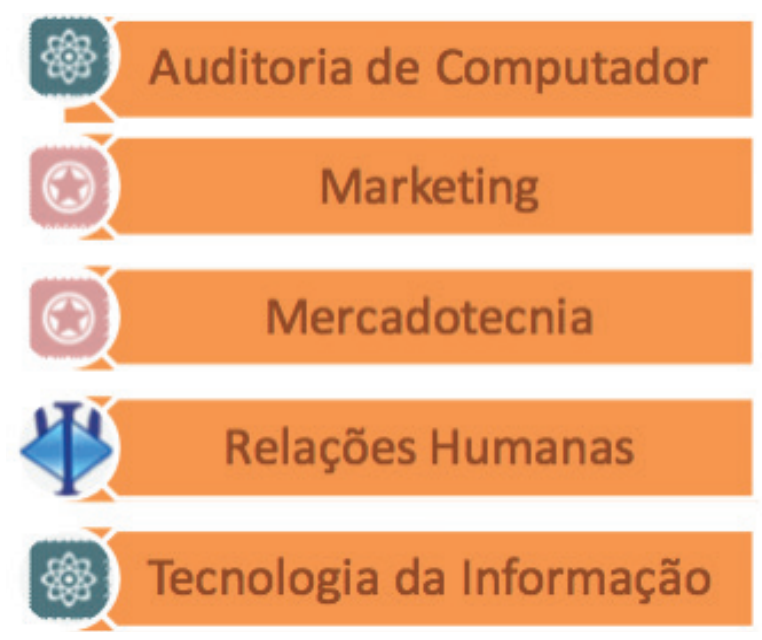

Figura 2: Disciplinas não específicas não necessárias na opinião dos entrevistados Fonte: elaborado pelos autores 
$\mathrm{Na}$ interpretação dos resultados pode-se perceber também que os respondentes possuem visões diferentes sobre as necessidades de cada disciplina de conhecimentos gerais.

Para Pereira, Wassen \& Caldas (2013) as disciplinas são valorizadas pelos alunos de acordo com a sua área de formação.

\begin{abstract}
Os estudantes dos cursos das áreas humanas se preocupam em receber uma formação mais geral, enquanto os estudantes dos cursos das áreas exatas, tecnológicas e da terra se preocupam em receber formação mais profissional. Há um entendimento geral de que estudantes das áreas humanas são mais preocupados com as questões sociais e por isso se preocupam com essa perspectiva na sua formação. Por outro lado, há um entendimento de que os estudantes das outras áreas estão mais focados nas questões técnicas de sua própria área de formação e a perspectiva de uma formação mais ampla e geral não é solicitada nem valorizada por eles;
\end{abstract}

Os estudantes que trabalham tendem a valorizar a ênfase profissionalizante como predominante. Grande número de estudantes universitários são trabalhadores e, por estarem no mercado de trabalho, tendem a valorizar uma formação que os auxilie a ganhar melhor colocação nesse mercado. Assim, a perspectiva cultural é pouco enfatizada por eles. (PEREIRA, WASSEN \& CALDAS, 2013).

Com o objetivo de conhecer a opinião dos respondentes foi perguntado se o tempo de integralização da grade curricular de, no mínimo, 5 anos, é adequado.

Três dos profissionais acreditam que sim e um entende que quatro anos seriam suficientes.

No Brasil os cursos de Bacharelado em Ciências Contábeis são integralizados em 4 anos e o bacharel para exercer a profissão de Contador precisa fazer a prova de suficiência do Conselho Federal de Contabilidade, no Paraguai os cursos são de 5 anos e o profissional exerce a profissão sem a obrigatoriedade de se filiar a nenhum conselho e não é submetido a análise.

A questão perguntou se o respondente acredita que o aluno de um curso de contabilidade a distância pode receber conhecimento da parte prática de forma adequada. 
Resposta 1: Sim, é possível, porém depende muito do aluno para aprender o conteúdo.

Resposta 2:Eu acredito que não é o mesmo aprendizado, porque presencialmente é mais fácil esclarecer dúvidas e esclarecer qualquer inquietude na realização da parte prática.

Resposta 3: Não, porque somente teria o conhecimento básico da contabilidade e não terá a oportunidade de discutir suas ideias e contrastar com a dos outros. Permaneceria somente com o que o autor dos livros diz e não com as ideias que podem desenvolver com a convivência em sala de aula entre professores e alunos, as perguntas são as ferramentas que um aluno tem para aprender.

Resposta 4: Sim, mas cada aluno tem que levar a sério e realmente querer adquirir conhecimento através de cursos à distância.

Como podemos observar as opiniões são divididas e todos os argumentos são coerentes, porém mesmo os que acreditam ser possível entendem que os alunos do ensino a distância precisam se esforçar, levar a sério, buscar informações e conhecimento. Morini (2006) que pesquisou sobre o perfil do aluno do ensino a distância entende que:

A aprendizagem em EAD, sendo midiatizada por novas TICs, requer dos alunos comportamentos e habilidades distintas dos exigidos no ensino convencional. Schrum e Hong, 2002 (apud RURATO, 2005) identificaram sete fatos significativos para que um aluno a distância seja bem sucedido:

- Acesso às ferramentas apropriadas;

- Experiência anterior com a tecnologia para assim, conseguirem utilizar corretamente todas as potencialidades da EAD.

- Preferências na aprendizagem;

- Hábitos e capacidades de estudo;

- Objetivos e propósitos;

- Fatores relacionados com o estilo de vida, como por exemplo, conseguir cumprir os prazos, desempenha um papel importante para conseguirem terminar um curso ou programa de EAD.

- Características pessoais, como a disciplina, a auto-organização, representam um dos fatores mais importantes e decisivos que contribuem para o sucesso ou não do aluno em curso a distância: os alunos bem sucedidos tendem a ter um forte comprometimento para colocar o seu tempo e esforço nos estudos.

Os educadores dizem que as diferenças individuais, tas como a falta de vontade, de autodisciplina e de organização, são fatores críticos que têm um forte impacto no sucesso de um aluno à distância, pois, existe um alto nível de responsabilidade pessoal que é solicitado aos estudantes para conseguir completar um curso. (MORINI, 2006). 
A pergunta seguinte indagou a opinião do respondente sobre se um aluno em um curso de contabilidade a distância tem as mesmas condições para praticar sua profissão de forma adequada como um estudante presencial.

Três responderam que sim e um respondeu que não pelos mesmos motivos da pergunta anterior.

Na conferência Mundial sobre a Educação Superior (UNESCO, 2009) no item 11 recomenda "preparar os alunos com conhecimentos, competências e habilidades que necessitamos no século XXI, no item 13, sugere que o aprendizado aberto e a distância e o uso das TICs oferecem oportunidades de ampliar o acesso a educação de qualidade e no item 51 convoca os estados membros a colaborar e apoiar uma maior integração das TICs e fomentar o aprendizado aberto e a distância com visão para satisfazer o aumento da demanda da educação superior.

A questão seguinte perguntou: O que você pensa sobre os cursos à distância?

Resposta 1:Eles estão acessíveis quando não há tempo suficiente para assistir às aulas.

Resposta 2: Esses cursos são acessíveis para todas as pessoas que não conseguem o tempo para ir para sala de aula ou por qualquer outra razão, não conseguem comparecer.

Resposta 3:Eles são bons para um aprendizado superficial, mas não para um aprendizado abrangente, bem empírico, porque se basearia somente na experiência do trabalho e ficaria sem saber o porque das coisas.

Resposta 4:Eles parecem excelentes porque você economiza tempo, tem a possibilidade de acessar muito mais tecnologia para investigar, conhecer e buscar informações.

Para Niskier (2000) a Educação a Distância é fundamental para que todos tenham acesso à educação superior.

\begin{abstract}
A Educação a Distância tornou-se a modalidade fundamental de aprendizagem e ensino, no mundo inteiro. Antes cercada de mistério, hoje é até mesmo reivindicada por sindicatos poderosos, no Brasil, onde o seu prestígio cresce de forma bastante visível. Parte-se de um conceito extremamente simples: alunos e professores separados por certa distância e, às vezes pelo tempo. A modalidade modifica aquela velha ideia de que, para existir ensino, seria sempre necessário contar com a figura do professor em sala e de um grupo de estudantes. (NISKIER, 2000)
\end{abstract}

\title{
5 I CONSIDERAÇÕES FINAIS
}

O caminho percorrido ao longo deste estudo pôde concluir que os alunos da modalidade à distância devem ter as mesmas obrigatoriedades e direitos dos alunos do ensino presencial. A legislação no mundo, como foi possível analisar lendo artigos e outros trabalhos sobre o assunto, prevê a proteção dessa modalidade e dos alunos que dela se 
utilizam para estudar, concluir e exercer uma profissão, na legislação e nas conferências mundiais.

Também foi possível perceber certa desconfiança e preconceito perante os alunos dessa modalidade de ensino, mesmo que o número de alunos tenha crescido nos últimos anos.

Neste estudo foi possível identificar que o aprendizado tem fatos bem relevantes porque de acordo com GUERRA (2011) o cérebro é o órgão da aprendizagem, mas a aprendizagem não depende apenas do funcionamento cerebral. A aprendizagem requer funções mentais como atenção, memória, percepção, emoção, função executiva, entre outras. Portanto, depende do cérebro. Mas a aprendizagem depende também de outros fatores, como condições gerais de saúde, ambiente familiar, estímulos na infância, interação social, tipos de escola, aspectos culturais, políticos, socioeconômicos e muitos outros.

O aprendizado depende muito do sujeito que o busca e o aluno do curso a distância precisa de disciplina e muita concentração para obter o mesmo aprendizado. $O$ aluno de um curso a distância é um aluno autodidata porque precisa aprender sozinho, precisa buscar informações, ler e pesquisar.

\section{REFERÊNCIAS}

AUGUSTO, José Prates A. Origem, evolução e objetivos da contabilidade. 2009. Disponível em <http:// professorprates.blogspot.com/2009/08/origem-evolucao-e-objetivos-da_25.html>. Acesso em 07 set. 2018.

BEUREN, Ilse Maria; BRANDÃO, Juliana Favero. Demonstrações Contábeis no Mercosul. São Paulo: Atlas, 2009.

BOGDAN, Robert; BIKLEN, Sari. Características da investigação qualitativa. In: Investigação qualitativa em educação: uma introdução à teoria e aos métodos. Porto, Portugal: Porto Editora, 1994.

BRASILEIRO, Ada Magaly Matias. Manual de produção de textos acadêmicos e científicos. São Paulo: Atlas, 2013.

COLEGIO DE CONTADORES DEL PARAGUAI. Disponível em <https://www.ccpy.org.py/>. Acesso em 25 set. 2018.

COGRESSO NACIONAL DE PARAGUAY. Disponível em <http://www.mic.gov.py/mic/site/comercio/dgcs/ pdf/7_ServiciosProfesionales/Ley371.pdf>. Acesso em: 25 set. 2018

CONSEJO DE CONTADORES PÚBLICOS DEL PARAGUAI. Disponível em <http://www.consejo.com.py/ index.php>. Acesso em 24 set. 2018.

CONSEJO NACIONAL DE EDUCACIÓN SUPERIOR. Disponível em <http://www.cones.gov.py/ley-4995-deeducacion-superior/>. Acesso em 26 set. 2018.

CONSEJO NACIONAL DE EDUCACIÓN SUPERIOR. Disponível em <http://www.cones.gov.py/wpcontent/uploads/2016/03/REGLAMENTO-DE-LA-EDUCACI \%C3\%93N-SUPERIOR-A-DISTANCIA-YSEMIPRESENCIAL.pdt>. Acesso em 25 set. 2018. 
EL PORTAL DE LOS ESTUDIANTES. Disponível em <https://www.altillo.com/ universidades/universidades_ Paraguai.asp>. Acesso em 26 set. 2018.

GIL, A. C. Métodos e técnicas de pesquisa social. 6. ed. São Paulo: Atlas, 2008.

GUERRA, Leonor Bezerra. 0 diálogo entre a neurociência e a educação: da euforia aos desafios e possibilidades. Revista Interlocução, v. 4, n. 4, p. 3-12, junho/2011. Disponível em: https://ufsj.edu.br/portal2repositorio/File/napecco/Abordagens/Ensino\%20e\%20 Aprendi zagem\%20no\%20Ensino\%20Superior.pdf. Acesso

LAKATOS, E. M.; MARCONI, M. de A. Fundamentos de metodologia científica. 6. ed. 5. reimp. São Paulo: Atlas, 2007.

MINISTÉRIO DE HACIENDA. DEPARTAMENTO DE NORMAS Y TECNICAS CONTABLES. Disponível em: < http://www.hacienda.gov.py/web-hacienda/archivo.php?a= f6k2fakff4f6f9k3f4fbfek4f6k4f8fefak8f6c4k2fakfc6cac8cac2ceceb5c2b5f9fab5f6f9k3fek4fek9kak8f6f8fek5k4b5fbfek4f6k4f8fefak8f6b5f9fak2b5fak9kaf6f9k5c3k6f9fbf6095\&x=f1f1090\&y=cdcd06c>. Acesso em: 04 out. 2018.

MORINI, Ana Maria. Um estudo sobre o perfil do aluno do ensino à distância. Palhoça, em: 07 out. 2018.

NISKIER, Arnaldo. Educação à distância - a tecnologia da esperança. São Paulo: Loyola, 1999.

PEREIRA, Elizabete Monteiro de Aguiar. WASSEN, Joice. CALDAS, Tania Alencar de. Formação profissional, básica ou geral: o que pensam estudantes da Unicamp. Revista Ensino Superior $n^{\circ} 10$ (julho-setembro), 2013.

RANKING WEB DE UNIVERSIDADES. Disponível em <http://www.webo metrics.info/es/Latin_America_es/ Paraguay>. Acesso em: 07 out. 2018

RICHARDSON, Roberto Jarry. Pesquisa social: métodos e técnicas. 3.ed. São Paulo: Atlas, 2008.

RIVAROLA, Domingo M. La Educación Superior Universitaria en Paraguay. Disponível em <http:// unesdoc.unesco.org/images/0014/001492/149229so.pdf>. Acesso em 28 set. 2018.

RURATO, Paulo; Gouveia, Luis Borges. Uma reflexão sobre o perfil dos aprendentes adultos no ensino a Distância (EAD). 2005. Artigo. CEREM - UFP, Portugal.

SAMPIERI, Roberto Hernández. COLLADO, Carlos Fernández, LUCIO, Maria del Pilar Baptista. Metodología de la Investigación. 5.ed. Mexico: McGraw-Hill, 2010.

SILVA, Cátia Beatriz Amaral da; MADEIRA, Geová José; ASSIS, José Luiz Ferreira de. Harmonização de Normas Contábeis: um estudo sobre as divergências entre Normas Contábeis Internacionais e seus reflexos na Contabilidade Brasileira. Revista Contemporânea de Contabilidade a. 01 v. 01 n. 01 jan./jun. 2004 p. 115-139.

UNIVERSIDAD AUTÓNOMA DE ASUNCIÓN. Disponível em <http://www.uaa.edu.py/educacion_a_distancia/ contabilidad.php>. Acesso em 23 set. 2018.

UNIVERSIDAD COLUMBIA. Disponível em: <https://www.columbia.edu.py/>. Acesso em 24 set. 2018.

UNIVERSIDAD NACIONAL DE ASUNCIÓN. Disponível em <http://www.una.py/>. Acesso em 02 out. 2018.

VERGARA, Sylvia Constant. Projetos e relatórios de pesquisa em administração. São Paulo: Atlas, 1997. 


\section{A IMPLANTAÇÃO DE UM SISTEMA CONTÁBIL/ FINANCEIRO EM UMA OPERADORA DE PLANO DE SAÚDE DA CIDADE DE FORMIGA-MG}

Data de aceite: $24 / 07 / 2020$

Data da Submissão: 20/07/2020

\section{Lucas Carrilho do Couto} Doutorando em Administração pela Universidade

Federal de Lavras (UFLA)

Professor do Centro Universitário de Formiga (UNIFOR-MG)

Divinópolis-MG http://lattes.cnpq.br/6681271601153995 lucascarrilho@yahoo.com.br

Fernanda Roberta da Silva Graduanda em Ciências Contábeis pelo Centro Universitário de Formiga (UNIFOR-MG)

Formiga-MG fernanda.r.silva498@gmail.com

RESUMO: Para que aconteça a transação de um sistema de gestão empresarial para outro é necessário que a empresa conte com a colaboração de todos os envolvidos, de modo que as mudanças ocorram dentro dos aspectos operacionais e técnicos da entidade e da legislação. Neste sentido, 0 presente estudo teve como objetivo descrever de que forma ocorreu a implantação de um sistema financeiro em uma operadora de planos de saúde da cidade de Formiga - MG, que se viu na obrigação de aprimorar seus procedimentos para atender às exigências de órgãos fiscalizadores. A metodologia utilizada se enquadra como uma pesquisa descritiva, no que concerne aos objetivos, qualitativa no tocante a abordagem e estudo de caso quanto aos procedimentos. Como resultados, verificouse que algumas mudanças precisam ocorrer para que a empresa continue tendo um bom funcionamento. Mas também é necessário se preparar para tais mudanças, pois se exige muito trabalho de todo pessoal envolvido, por ser um processo demorado e muitas vezes desgastante. Deve-se observar os pontos positivos e negativos que uma transação desse porte pode trazer e estar preparado para alguns imprevistos.

PALAVRAS-CHAVE: Implantação de sistema, operadora de planos de saúde, exigência de órgãos fiscalizadores.

\section{THE IMPLEMENTATION OF AN}

ACCOUNTING / FINANCIAL SYSTEM IN A HEALTH PLAN OPERATOR IN THE CITY OF FORMIGA-MG

ABSTRACT: For the transaction to happen from one business management system to another it is necessary for the company to count on the collaboration of all those involved, so that the changes occur within the operational and 
technical aspects of the entity and the legislation. In this sense, the purpose of this study was to describe how a financial system was implemented in a health plan operator in the city of Formiga - MG, which was obliged to improve its procedures to meet the requirements of supervisory bodies. The methodology used is classified as a descriptive research, regarding the objectives, qualitative regarding the approach and case study regarding the procedures. As a result, it has been found that some changes need to occur in order for the company to continue to function well. But it is also necessary to prepare for such changes, since it requires a lot of work from all personnel involved, because it is a time consuming and often exhausting process. One should note the positives and negatives that a transaction of this size can bring and be prepared for some unforeseen events.

KEYWORDS: System implementation, health plan operator, requirement of auditing agencies.

\section{I INTRODUÇÃO}

Com a informatização as empresas estão cada vez mais modernas e aptas para atendimento das demandas do mercado. Principalmente nos dias atuais, a tecnologia é primordial na geração de informações atualizadas, rápidas e corretas para o bom funcionamento das organizações. Desse modo, valores significantes são investidos em novas tecnologias que objetivam maior compreensão e eficiência do negócio.

Dentro de uma organização, todas as etapas são importantes, desde o primeiro momento em que um pagamento é provisionado até quando ele é efetuado, desde quando um serviço é prestado ou uma mercadoria é vendida até o recebimento de uma duplicata. Controlar todos estes processos, apenas com o trabalho manual dos profissionais, seria demorado. passível de altos índices de erro e oposto ao que é demandado e exigido pelo mercado atual, que fomenta rotinas cada vez mais aceleradas e com prazos estabelecidos para cada processo. Com a informatização é possível dirimir a papelada, ganhar tempo e reduzir gastos, ou seja, ser mais eficiente.

Quando se fala em informatização da empresa, subentende-se um galpão cheio de máquinas modernas, controladas por robôs. Mas a modernização na parte administrativa e contábil é tão importante quanto as modificações da produção. Destacam-se neste quesito, por exemplo, a criação do Sistema Público de Escrituração Digital (SPED), através do Decreto $n^{\circ} 6.022$ de Janeiro de 2007 e a emissão de Nota Fiscal Eletrônica (NFE) e Escrituração Contábil Digital (ECD), criadas pela Instrução Normativa da Receita Federal do Brasil (RFB) $n^{\circ} 787$ de 19 de Novembro de 2007, que substituem os livros contábeis (razão e diário). Todas estas incorporações possuem a finalidade de reduzir o número de sonegações através do cruzamento de informações e proporcionar o melhor controle tributário com o envio de relatórios e declarações ao fisco de forma totalmente informatizada. Assim, a informática evoluiu de uma mera auxiliadora de suporte administrativo para exercer um papel de destaque e diferencial dentro da organização. A 
produção de informações mais precisas e coerentes que auxiliem nas rotinas só passa a ser possível com a modernização dos sistemas operacionais (LAURINDO et al, 2001).

Uma pesquisa realizada pelo Serviço Brasileiro de Apoio às Micro e Pequenas Empresas (SEBRAE) em 2016 mostrou que uma empresa no estado do Paraná, que atua no segmento de Tecnologia da Informação ( $\mathrm{TI}$ ), sempre se destacou pelo seu atendimento diferenciado. Porém em certo momento começou a perder clientes porque não conseguia acessar as opiniões que eles tinham sobre a empresa e seu atendimento, dificultando a possibilidade de melhorar diante da insatisfação deles.

Preocupados com a situação, esta empresa criou uma nova rotina para o pós venda. Desenvolveu um sistema operacional que agendava uma ligação para cada nova venda que era efetuada e assim era possível pesquisar o grau de satisfação dos clientes. As informações eram aglomeradas em uma tela de pós-atendimento e assim o colaborador poderia analisar os atendimentos de acordo com o status de cada cliente. As vendas passaram a ser monitoradas pelo sistema e o controle a ser feito de forma automatizada. Os clientes passaram a ter a oportunidade de fazer elogios ou críticas aos serviços prestados e a empresa pôde responder a eles em tempo hábil melhorando o atendimento.

Com a expressiva contribuição do sistema a organização teve bons resultados, dentre eles: os profissionais agora desempenham suas atividades com mais eficiência e tranquilidade, aumentou a produtividade dos colaboradores, elevou a satisfação dos clientes em $96 \%$, reduziu o número de cancelamento de contratos, colaborou com o crescimento da carteira de clientes, dentre outros aspectos.

Assim, diante da necessidade tecnológica cada vez mais latente, concomitante à finalidade de uma operadora de plano de saúde, que atua na cidade de Formiga MG desde 1992, em diminuir riscos com órgãos fiscalizadores e modernizar sua gestão administrativa/financeiro/contábil, o presente estudo teve como objetivo descrever de que forma ocorreu a implantação de um sistema financeiro em uma operadora de planos de saúde da cidade de Formiga - MG.

No que se refere à organização estrutural do artigo, ressalta-se que além desta breve Introdução, o trabalho está estruturado em mais quatro seções. Na próxima são apresentados os principais conceitos teóricos e práticos relacionados ao tema de pesquisa. A terceira seção contempla os caminhos trilhados para seu desenvolvimento, isto é, os procedimentos metodológicos. Os resultados são apresentados na quarta seção. E, por fim, na quinta seção, apresentam-se as considerações finais.

\section{I REFERENCIAL TEÓRICO}

Este capítulo é composto pela revisão de literatura que sustenta a pesquisa e contempla os seguintes temas: origem da contabilidade, conceito e objetivo da contabilidade e a tecnologia e a contabilidade. 


\subsection{Origem da contabilidade}

Pode se afirmar que a contabilidade é tão antiga que os primeiros sinais da existência de contas puderam ser notados há aproximadamente 2000 antes de Cristo (a.C.). Porém, em um período anterior a este o homem primitivo ao catalogar seus objetos de caça e pesca, enumerar seu rebanho, contar seus barris de bebida, praticava uma forma arcaica de contabilidade. Os Incas dependuravam cordas coloridas nas quais eram dados nós que representavam seus pertences (OLIVEIRA, 2014). No terceiro milênio a.C. nos povos sumérios da Babilônia e Mesopotâmia (onde hoje é o Iraque), no Egito e na China, foi possível localizar os primeiros sinais completos de contabilidade (IUDíCIBUS, 2015). Eles catalogavam seus bens através de um método denominado como escrita cuneiforme em tabuleiros feitos de argila. No Egito utilizavam-se os papiros para os registros. Quando vários papiros eram reunidos e costurados formavam um livro rudimentar (OLIVEIRA, 2014).

Mas como exercer a arte de contar em uma época que não existiam números e letras? Em uma determinada estação, um homem com seu tempo ocioso desperta a curiosidade em saber quanto seu rebanho cresceu de uma estação para outra. Decide então utilizar um monte de pedrinhas para marcar a quantidade de ovelhas que ele possuía, cada uma representava uma ovelha. Surgia o primeiro modelo de inventário. Este homem era ambicioso e queria superar desafios. Ele queria que seu rebanho sobressaísse o do seu vizinho. Aparecem então os primeiros sinais de Contabilidade bem no início da civilização, a partir da preocupação do homem com seu patrimônio, se ele cresceu ou diminuiu (IUDÍCIBUS; MARION; FARIA, 2017). Neste período, a contabilidade era utilizada apenas para controlar animais e estoques de produtos agrícolas (SANTOS; SCHIMIDIT; MACHADO, 2005).

Na Bíblia sagrada também há rastros dos primórdios da contabilidade. O livro de Jó conta que ele era um homem muito rico e relata com detalhes a quantidade de gado, ovelhas, camelos, juntas de bois e jumentas que ele possuía em seu rebanho. Essa descrição demonstra uma preocupação com o controle das posses de Jó. Em um dado momento, ele perde todo seu patrimônio e se torna um homem pobre. Ao final da história, consegue recuperar todos seus bens e há registros que comprovam ainda que sua fortuna havia duplicado. Nota-se portanto a forte presença da contabilidade que registra cada movimentação patrimonial de Jó, mesmo que os recursos matemáticos, de letras e de negócios fossem limitados. Desse modo, a Contabilidade é ainda mais antiga do que se possa imaginar (IUDÍCIBUS; MARION; FARIA, 2017).

Ao analisar a evolução da contabilidade pode ser percebido que esta é uma área cujo progresso sempre esteve atrelado ao desenvolvimento de atividades comerciais, sociais e econômicas (FAVERO et al, 2011). A Contabilidade existe desde o começo da civilização, mas seu desenvolvimento foi lento ao decorrer dos séculos. Os números indo-arábicos 
surgiram no século XIII para substituir os greco-romanos e hebraicos que utilizavam as letras para calcular e contar. No ocidente a história dos números surge em 1202 com o livro Liber Abaci (Livro do Ábaco), escrito por Leonardo Pisano, que incluía cálculos de margens de lucro, câmbio, moedas e juros. Portanto, não há como falar em Contabilidade sem mencionar a invenção da escrita e, com ela, a capacidade de contar, ou seja, o início do raciocínio matemático do homem. Outro ponto que se destaca na evolução Contábil é o surgimento da moeda como símbolo de troca por volta do ano 2000 a.C. (apesar que outros tipos de metais já eram utilizados nas transações financeiras há algum tempo). Assim, antes da criação do método por partidas dobradas, era possível mensurar bens, direitos e obrigações cotidianamente para identificar o patrimônio líquido das entidades. O fechamento dos períodos era feito através da diferença entre os patrimônios líquidos em datas diferentes, sem preocupar em descobrir o motivo das variações do mesmo. Esta foi a forma encontrada para gerar um balanço que demostrasse os fatos contábeis. A estruturação dos registros que criaria as demonstrações contábeis surgiu somente mais tarde de forma incoerente e suplementar (as partidas simples) até o surgimento das partidas dobradas e das escriturações contábeis (IUDíCIBUS; MARION;FARIA, 2017).

No norte da Itália o desenvolvimento econômico provocado pela expansão da população colaborou com o aparecimento das partidas dobradas (SANTOS; SCHIMIDIT; MACHADO, 2005). Luca Paciolli foi um frade franciscano que viveu na Itália no século $\mathrm{XV}$, nos tempos de Leonardo da Vince e marcou o começo da fase moderna, apontando o débito e o crédito como correspondentes aos números positivos e negativos, ou seja, o mesmo valor que for lançado nas contas de débito deve ser lançado nas contas de crédito. Surge a contabilidade por partidas dobradas (IUDíCIBUS; MARION; FARIA, 2017).

Depois do aparecimento do método por partidas dobradas e após dispersão da escola Italiana em toda Europa, nasce no século XIX o período denominado por muitos como científico. Neste período, pela primeira vez a teoria progride em relação às reais necessidades e dificuldades das sociedades. Este momento discorre também na Itália que influenciou o cenário contábil até os vinte primeiros anos do século $X X$. Em seguida surgem Fabio Besta, Giuseppe Cerboni, Gino Zappa e mais recentemente, Aldo Amaduzzi, Teodoro D'Ippolito e muitos outros que tiveram seus trabalhos reconhecidos por criarem discursões entres os seguidores de um ou outro ideal. Assim é ressaltado o interesse de vários estudantes que acompanhavam a evolução da contabilidade. Nesta época existiam vários trabalhos de valor imensurável. No entanto, devido à falta de provas de algumas ideias e ao excesso de "culto da personalidade" que surgiu entre alunos e mestres a popularidade da Escola Italiana começa a despencar e perde seu incomparável destaque. Mesmo assim continuou a produzir alguns trabalhos, tanto quanto repetitivos, demasiadamente teóricos e sem muito apoio dos autores em suas pesquisas, somente uma disseminação de ideias. (IUDíCIBUS, 2015).

A Contabilidade no Brasil foi desenvolvida em duas partes, sendo uma antes de 1964 
e outra depois. Mesmo que o Brasil não tenha tido uma escola de pensamento contábil autêntica, encontram-se várias colaborações teóricas e práticas no País. Além disto, há uma intervenção duradoura da legislação desde o princípio (SANTOS; SCHIMIDT; MACHADO, 2005).

A legislação contábil referente às demonstrações contábeis que são publicadas todo ano é uma das mais aprimoradas do mundo. Alguns autores se destacam no cenário brasileiro dentre eles, Carlos de Carvalho, Francisco D’Auria, Frederico Hermann Júnior, Hilário Franco, Antônio Lopes de Sá, Américo Mateus Florentino e mais atualmente professores da Universidade de São Paulo (USP). Na avaliação mundial de contribuições de cada um pode-se dizer que, especialmente na Europa, D'Auria é o que mais se destaca na Contabilidade brasileira (IUDÍCIBUS; MARION; FARIA, 2017).

No reino de D. João VI em 1808 ocorreu umas das primeiras demonstrações contábeis brasileiras, por meio da divulgação de um alvará que impunha aos contadores da Fazenda Real que aplicassem o método das paridas dobradas na escrituração mercantil. Em 1850 aconteceu um dos primeiros pronunciamentos da legislação, o Código Comercial que estabeleceu que a escrituração contábil fosse obrigatória e a demonstração do balanço anual fosse elaborada anualmente. Alguns eventos que marcaram a evolução da Contabilidade no Brasil foram: a publicação do livro Manual mercantil, escrito por Veridiano de Carvalho, em 1880; a criação da Escola de Comércio Álvares Penteado, em 1902; a publicação do Decreto no 20.158 em 1931 (estruturou o ensino comercial e regulamento a profissão contábil); a publicação do Decreto $\mathrm{n}^{\circ} 2.627$, a primeira Lei das Sociedades por ações; a profissão de contabilidade foi considerada como carreira universitária no ano de 1945; em 1946 foi fundada a instituição do curso de Ciências Contábeis e Atuariais - fundação FEA-USP, a formação dos Conselhos Reginonais de Contabilidade (CRCs) e do Conselho Federal de Contabilidade (CFC); 1947 marcou a divulgação do Decretolei $n^{\circ} 24.239$ que assentiu a revisão de ativos fixos equivalentes a uma reserva especial no Patrimônio Líquido entre muitos outros eventos importantes. Mais recentemente se destacam a publicação da Resolução CFC 750 em 1993 que designou novos princípios contábeis; no ano de 1995 foi publicada a Lei n 9.245 que acabou com a correção monetária das demonstrações de contabilidade e em 2001 a publicação da atual Lei das Sociedades por Ações, a Lei nº 9.245 (SANTOS; SCHIMIDT; MACHADO, 2005).

\subsection{CONCEITO E OBJETIVO DA CONTABILIDADE}

A contabilidade é a ferramenta que gera informações relevantes aos usuários internos e externos para auxiliar na tomada de decisão. Está presente na humanidade há muito tempo e sempre teve esta finalidade. Toda movimentação que acontece dentro de uma empresa é registrada pela contabilidade, que através destas, gera relatórios que são entregues aos interessados que desejam entender a situação financeira da empresa para 
tomarem decisões relevantes em ralação ao futuro da mesma (MARION, 2009).

Seu objetivo principal é o controle de um Patrimônio, feito através do recolhimento de informações, que em seguida são armazenadas e processadas em forma de relatórios que destacam as alterações patrimoniais. O recolhimento das informações é feito através de todo um processo e conta com um conjunto de técnicas perante a aplicação de princípios, normas e procedimentos próprios, mensura, interpreta e repassa as informações de uma forma clara e concisa aos donos das entidades (PADOVEZE, 2000).

Além disso, a contabilidade fornece informação estruturada relativamente econômica, financeira e de produtividade social aos interessados no patrimônio da empresa que é o objeto da contabilidade. Informação estruturada que dizer que ela segue um padrão de planejamento contábil com o auxílio de um sistema financeiro criado e revisado regularmente levando em conta os próprios parâmetros (IUDíCIBUS; MARION; FARIA, 2017).

Adiante a sociedade se preocupa com seus bens, se eles foram valorizados ou não, se são distribuídos de forma justa ou não. Para fazer seu acompanhamento é preciso de um sistema que possa mensura-lo. E é aí que a Contabilidade entra. Através da demonstração de resultado, por exemplo, é possível julgar se uma organização teve lucro ou prejuízo. Para avaliar a riqueza de uma entidade também é utilizado o sistema contábil, através do balanço patrimonial. Há várias formas de descrever a contabilidade, mas ela é considerada importante, não apenas para auxiliar na tomada de decisões, mas também é essencial para medir a situação financeira e econômica de uma determinada empresa (BARKER, 2012).

A contabilidade também pode ser denominada como uma ciência social aplicada que está em contínua mutação. Alguns teóricos oferecem vários pontos de vista onde a contabilidade acaba tendo várias respostas para uma mesma questão. Mas, o fato é que ela ainda não dispõe de uma teoria geral. Um conjunto de hipóteses financeiras, econômicas, matemáticas, entre outras, fundamentam desde sua prática até seu desenvolvimento científico (NIYAMA, 2014). Portanto, a contabilidade é uma ciência que tem como objeto de estudo o patrimônio e utiliza de meios desenvolvidos especialmente para recolher, inventariar, condensar, sintetizar e analisar as ocorrências que atingem a situação patrimonial de uma pessoa seja ela física ou jurídica (GONÇALVES; BAPTISTA, 2011).

Assim, a contabilidade tema função fundamental de gerar informações referentes à situação patrimonial, o comportamento e as variações na parte financeira das empresas que sejam importantes a um extenso número de usuários em suas análises e tomada de decisões. Essa análise propicia duas formas de avaliação: interna e externa, sendo a primeira efetuada pelos sócios, administradores e investidores e a segunda, aos agentes do mercado, financeiro ou operacional. Todos estes utilizam das informações contábeis, principalmente, no que se refere à capacidade de geração de caixa ou 
equivalentes que a empresa possui em determinado período de tempo através do controle e do investimento de recursos. Por fim, essa capacidade apontará se a empresa poderá pagar seus fornecedores, sua folha de pagamento e as despesas financeiras adquiridas por transações bancárias, sem contar a capacidade de distribuir dividendos aos seus acionistas ou quotistas (FERNANDES; NETO, 2014).

\subsection{A TECNOLOGIA E A CONTABILIDADE}

A tecnologia está cada vez mais presente em diversos espaços da vida social. Os computadores são prova das inovações tecnológicas sendo utilizadas nas mais variadas atividades exercidas pelos usuários. Uma das principais causas do desenvolvimento tecnológico é o uso generalizado do computador nas últimas décadas (VELOSO, 2011). Assim para as empresas desenvolverem bem suas atividades é necessário a departamentalização de sua estrutura em vários setores. Dentre as quais se destacam como geradores de informação para a administração geral das empresas comerciais e de serviço as esferas administrativas, comerciais, contábeis e financeiras.

No passado a contabilidade de uma empresa era vista apenas como um setor de controle interno por exercer várias atividades ligadas a ele. Atualmente os mecanismos de controle interno são feitos fora da área da contabilidade. As informações sobre os clientes, por exemplo, eram fornecidas pela Contabilidade e também era usada uma ficha individual chamada "Kardex" onde eram registradas todas as movimentações de cada cliente e tudo era resumido em uma ficha sintética denominada "Clientes". Essa ficha também era usada para o controle de estoques. O número de registros variava de acordo com o porte da empresa, assim como acontecia com a ficha de fornecedores que possuía registros analíticos e sintéticos. Com o surgimento da TI os registros contábeis passaram a ser incorporados à várias áreas da entidade, ou seja, fora da área Contábil (OLIVEIRA, 2014).

A TI englobava computadores e softwares direcionados para armazenar, processar e analisar informações. Nos anos 80 , quando os computadores pessoais se tornavam populares por seus programas de entretenimento e planilhas eletrônicas, surgiram as Tls de escritório que automatizavam os processos e enfatizava o gerenciamento de documentos, controle de compromissos e à comunicação interna e externa do estabelecimento. Já na década de 90 surgiu a Internet a partir de uma tecnologia denominada Transmission Control Protocol/Internet Protocol (TCP/IP) e Word Wide Web (WWW) que facilitou muito a comunicação rápida entre uma localidade e outra. Assim surgiu conceito de "estar na rede" através de sites, portais de conteúdo jornalístico e entretenimento, bate-papos interligados a ferramentas de busca, etc. E consequentemente as empresas aderiram ao "estar na rede", primeiro indo atrás de informações, e em seguida buscaram melhorar 
seu relacionamento com seus fornecedores, clientes e também através de transações bancárias cada vez mais seguras e cômodas para seus usuários (GONÇALVES; RICCIO, 2009).

Os sistemas de informação permitem que os gestores das empresas tenham ciência das movimentações ocorridas dentro da entidade (especialmente no que tange aos reflexos econômicos) para que eles julguem adequadamente cada situação em tempo hábil dando destaque aos itens de maior relevância para auxiliar em sua tomada de decisão. É considerado como "bom" o sistema de informação que permite ao seu usuário extrair dele os dados em tempo oportuno e com menor custo possível. E neste caso, o banco de dados deve ser ágil, flexível, bem montado, com base no envolvimento e na adequação das necessidades dos usuários. Esse ajuntamento em um cenário como o de hoje, tendo como palavras de ordem competitividade e modernidade, as tecnologias de informações deve ser muito bem analisado pelos administradores. Além disso, a tecnologia ligada ao banco de dados divide espaço com a tecnologia de conectividade, que pode ser tanto física (equipamentos) ou lógica (softwares) decorrente da habilidade de desfocar o processamento empresarial e reconsiderar o Centro de Processamento de Dados (CPD). Isso faz com que o usuário que precisa do computador tenha maior acessibilidade ao mesmo (CORNACCHIONE JR, 2012).

A Contabilidade é uma das principais áreas de uma empresa em que sistemas e programas exclusivos podem ser criados a partir de seu nível de procedimentos e estruturas, já que recebem e manipulam dados decorrentes de transações ocorridas nos demais departamentos. O Sistema de Informação utilizado pela empresa deve entender a relação destes departamentos para que o trabalho seja desenvolvido de forma precisa, especialmente porque algumas das informações são repassadas a órgãos governamentais, como impostos, obrigações trabalhistas, entre outros (BATISTA, 2012).

\subsection{ESTUDOS RELACIONADOS}

Cruz, Dacol e Rebelo (2008) afirmam que quando se fala em sistemas para empresas de pequeno porte eles não são tão importantes. Porém, quando se trata de empresas maiores eles são indispensáveis. Segundo as autoras, as informações exatas e rápidas podem auxiliar aos administradores a tomarem boas e apropriadas decisões. Quando se utiliza sistemas de informação integrados à Contabilidade as operações que interferem no Patrimônio Líquido são registradas de forma eficiente e em tempo real. Um sistema ou um novo sistema pode ser desenvolvido para atender a necessidades externas como por exemplo, da Receita Federal ou necessidades internas como, auxiliar a que manuseia o programa a identificar registros inconsistentes, chamar a atenção para avisos importantes, bloquear clientes inadimplentes, entre outros. Por proporcionar uma rápida avaliação na situação da empresa, ágil consolidação de dados e colaborar nas projeções, os sistemas 
permitem uma melhor preparação no plano estratégico e esclarece a tendência global.

Peleias et al (2009) analisaram o entendimento dos usuários da Contabilidade em relação a implantação, o desempenho e uso de um sistema Enterprise Resource Planning (ERP) criado para o setor de transporte rodoviário de cargas e passageiros. Eles fizeram uma pesquisa quantitativa que combinou levantamento de campo, investigação empírica e revisão bibliográfica. Foi identificado que os sujeitos analisados entendem a facilidade e a importância de um sistema ERP, mas dividem opiniões entre otimistas, pessimistas e realistas e ressaltam alguns pontos do sistema que podem ser aperfeiçoados.

Por fim Tavares (2014) utilizou uma empresa fornecedora de energia elétrica para mostrar os impactos da geração de informação contábil através da implantação de um ERP. O autor realizou uma revisão bibliográfica em relação a sistemas integrados e particularidades importantes da contabilidade. Coletou dados por meio de entrevistas com colaboradores do departamento contábil e administradores da companhia. Abordou aspectos qualitativos da informação contábil com credibilidade no momento da geração da informação para a tomada de decisão antes e depois do processo de implantação do ERP e concluiu que estes sistemas agilizam e melhoram processos, reduzem tempo para gerar as informações e aumentam a confiança dos usuários devido a correção de erros identificados durante o procedimento de tratamento de dados, que afastam a incoerência de informações geradas por cada departamento.

\section{I PROCEDIMENTOS METODOLÓGICOS}

Nesta seção foram abordados os aspectos metodológicos usados na condução do estudo. Apresentou-se uma breve classificação metodológica da pesquisa, uma delimitação sobre o universo e amostra da pesquisa, e a fonte e os procedimentos que foram utilizados para a coleta dos dados.

\subsection{CLASSIFICAÇÃO DA PESQUISA}

Quanto aos objetivos, o presente trabalho foi desenvolvido mediante a uma pesquisa descritiva. Wickert (2013) explica que este tipo de pesquisa se configura por estar entre uma pesquisa explicativa e exploratória, ou seja, não é tão superficial como na primeira e nem aprofunda tanto como a segunda. Sendo assim, descrever quer dizer reconhecer, expor e confrontar entre outros. Segundo Andrade (2010), esse tipo de pesquisa observa os fatos e em seguida eles são registrados, estudados, classificados e explicados sem que o pesquisador apareça envolvido neles. Uma de suas principais características é a técnica padronizada da coleta de informações, que pode ser efetuada através de questionários ou da observação sistemática.

Quanto aos procedimentos foi feito um estudo de caso. Segundo Wickert (2013) no 
estudo de caso a principal característica é o estudo centralizado de um único caso. Para os pesquisadores que desejam aprofundar seus conhecimentos em um caso específico, esse é o método que deve ser utilizado. Esse tipo de pesquisa requer mais intensidade pelo fato de que os esforços dos pesquisadores se concentram em determinado objeto de estudo. Para Lakatos, Marconi (2017) o estudo de caso reúne inúmeras informações detalhadas utilizando de várias técnicas de pesquisa com o objetivo de compreender determinada situação e detalhar a complexidade de um acontecimento.

Já no que se refere à abordagem, tratou-se de uma pesquisa qualitativa, que de acordo com Appolinário (2016) prevê a coleta de dados sobre o fenômeno pesquisado pelo pesquisador. A análise de dados também pode ser feita através da interpretação de texto do próprio pesquisador. Além disso, esse tipo de pesquisa não permite generalizações, sendo assim, não se pode tirar dela previsões nem leis que possam ir além do que está sendo pesquisado. Segundo Lakatos, Marconi (2017) esta modalidade de estudo se desenvolve em uma situação natural com riqueza de informações que descrevem detalhadamente os dados.

\subsection{OBJETO DA PESQUISA}

O presente trabalho foi feito em uma operadora de planos de saúde situada na cidade de Formiga - MG. Ela conta com o apoio de 46 colaboradores, 112 médicos credenciados, 15 laboratórios, 3 hospitais, 71 clínicas especializadas e atende a 116 mil clientes. Ela faz parte de um sistema cooperativista criado em 1967, na cidade de Santos que visava o ideal de aproximar pacientes e médicos. Hoje este sistema atua em todo território Nacional, sendo aproximadamente 377 entidades que atendem mais de 15 milhões de pacientes e 75 mil empresas em todo país. Conta também com aproximadamente 106 mil médicos, 3 mil hospitais, e ainda clínicas, laboratórios, pronto atendimentos, dentre outros.

\subsection{FONTE E COLETA DE DADOS}

Os dados para elaboração deste trabalho foram coletados diretamente na entidade que tem sua sede na cidade de Formiga - MG. As informações presentes no estudo foram repassadas diretamente pelas colaboradoras que participaram de toda transação, desde o início. Elas relataram os pontos positivos, os pontos negativos, o motivo pelo qual foi preciso trocar o sistema, principalmente quais foram os impactos causados durante todo processo e quais destes impactos foram mais relevantes.

Foram feitas algumas perguntas diretamente a cada uma delas, e elas se propuseram a responder imediatamente de forma bastante detalhada como foi cada momento da transição. Elas contaram como era sua rotina de trabalho e o que foi preciso mudar para aderir ao novo sistema, pois, além da alteração do software, houve algumas reestruturações 
nos setores e também nas próprias rotinas de trabalho.

\section{I RESULTADOS E DISCUSSÃO}

Este tópico foi elaborado de acordo com as informações repassadas pelos colaboradores da empresa e é composto pelos seguintes temas: características da empresa e análise dos dados; perfil do novo sistema implantado na empresa; a implantação do novo sistema; aspectos positivos observados no processo de implantação do sistema e aspectos negativos observados no processo de implantação do sistema.

\subsection{CARACTERÍSTICAS DA EMPRESA E ANÁLISE DOS DADOS}

A coleta dos dados foi feita através de uma entrevista realizada com as colaboradoras dos setores Financeiro e Contábil com objetivo de descrever o processo de implantação de um novo sistema em uma operadora de planos de saúde na cidade de Formiga - MG. A empresa escolhida visa a grande importância de estar sempre atualizada e dentro das exigências legais. Desta forma, julgou imprescindível a necessidade de um sistema que permitisse a integração de todos os setores da empresa.

Esta operadora de planos de saúde está departamentalizada entre os setores de autorização/atendimento, comercial, cadastro, faturamento, auditoria, jurídico, arquivo, tecnologia da informação e, os principais deste estudo de caso, financeiro e contabilidade. Nestes dois últimos são desempenhadas as seguintes atividades: folha de pagamento de médicos cooperados, contas a pagar, controle de inadimplência, conciliação bancária, lançamento de duplicatas, geração de boletos e notas fiscais, dentre outras, rotinas pertencentes ao setor financeiro; e registros trabalhistas, envio de relatórios fiscais, folha de pagamento de colaboradores, controle de impostos, fornecimento de informações para auxiliar na tomada de decisões, dentre outras rotinas que são desempenhadas pelo setor de contabilidade.

Estes departamentos trabalham diretamente interligados. Cada um deles possuía um módulo específico que não era integrado para a realização das atividades. Existiam dois sistemas diferentes, um para cada departamento. Porém, estes dois programas não se comunicavam entre si. Todos os dados eram gerados em forma de arquivos padrão, e em seguida eram absorvidos pelo financeiro e depois repassados para a contabilidade. No entanto, o sistema utilizado pela contabilidade não era capaz de suportar estes dados extraídos. Com isso precisavam de um terceiro programa que convertia os dados em uma linguagem que o sistema contábil entendesse. Somente após serem convertidos eram importados pela contabilidade. Todo este processo demandava muito tempo e desgastava muito os responsáveis por esta rotina além de possibilitar uma maior probabilidade de erro durante o processo. 
Além disso, os departamentos executavam suas atividades através de um software desenvolvido em determinada plataforma que não integrava com os demais módulos e que não realizava a importação das respectivas informações. Assim, além do problema das importações, exportações e conversões dos arquivos, era necessário fazer controles internos em planilhas eletrônicas para o desenvolvimento de relatórios para conferência de produção por exemplo. Todo procedimento da integração era feito manualmente, uma vez que o antigo sistema não possuía recursos para isso.

Esta forma de trabalho já vinha sendo empregada há muitos anos e o sistema que era utilizado estava muito ultrapassado em relação aos atuais. E como a entidade é regulamentada pela Agência Nacional de Saúde (ANS), que determina sua própria legislação e possui seu próprio plano de contas, o sistema antigo já não oferecia atualizações que atendessem tais exigências, deixando a empresa vulnerável à órgãos fiscalizadores.

A busca pela melhoria no desempenho das tarefas diárias, a otimização de tempo, o fornecimento de informações mais precisas e corretas, além da eliminação de riscos com órgãos fiscalizadores, foram fatores primordiais que influenciaram a diretoria a investir em um sistema mais moderno e eficiente para a empresa. Ressaltam-se também outros motivos importantes que cooperaram nesta decisão, como a redução de custos e o aumento na qualidade dos serviços desempenhados.

\subsection{PERFIL DO NOVO SISTEMA IMPLANTADO NA EMPRESA}

O novo sistema é um software de gestão composto por diversos módulos que abrangem todos os setores da empresa e a maioria das demandas de uma operadora de planos de saúde, como por exemplo, autorizador de procedimentos online, faturamento das contas médicas, auditoria, cadastro, parte financeira, contábil entre outras áreas essenciais ao bom funcionamento da entidade. É um software capacitado para integrar informações, já que trabalha interligado com outro sistema que atende financeiro e contabilidade, pois ambos falam a mesma linguagem.

O sistema é atualizado periodicamente de acordo com as exigências da ANS, e garante aos usuários a tranquilidade de estarem fazendo seu trabalho de acordo com as demandas legais. Ele permite que as informações cadastradas em um determinado módulo possam ser usadas por outro sem qualquer tipo de conversão, além de possuir também um sistema de exportação de dados que permite a geração de relatórios em planilhas eletrônicas, caso necessário.

A integração direta entre financeiro e contábil foi o que mais agradou aos usuários. E mesmo que os dois departamentos ainda precisem de dois sistemas para desempenhar suas atividades, agora ambos utilizam a mesma linguagem e não precisam de um terceiro para converter os dados de um departamento para o outro. A integração com os outros 
setores ainda é feita por partes, mas com o processo de atualização constante, os colaboradores esperam que todos os departamentos estejam interligados e as informações cheguem para a contabilidade em tempo real.

De acordo com uma das usuárias do sistema, outros pontos importantes merecem destaque, como o fato de que ele oferece um bom suporte técnico, a redução de custos e a confiabilidade dos dados, o que transmite mais tranquilidade aos usuários ao desempenharem suas funções.

\subsection{A IMPLANTAÇÃO DO NOVO SISTEMA}

As principais mudanças trazidas à entidade e ao seu funcionamento foram observadas e analisadas neste tópico. Os setores melhoraram todas as rotinas com a adoção do novo sistema. Dentre as etapas que marcaram a implantação do novo sistema, destacam-se a escolha do software ideal, a introdução das informações pertinentes ao funcionamento do sistema, a adaptação e aprendizado dos colaboradores, entre outras.

A gestão da empresa já planejava investir em um novo sistema há algum tempo, pois o antigo software estava ficando ultrapassado e não atendia à legislação vigente, que passa por constantes transformações. Em relato uma das colaboradoras mencionou que existem documentos específicos e declarações que são enviadas ao órgão regente das operadoras de planos de saúde mensalmente, trimestralmente e anualmente, que contém informações específicas da saúde financeira da empresa, do atendimento a beneficiários, dentre outros. Isto é, através destes arquivos o órgão regente fiscalizador monitora todo o funcionamento das entidades. Até certo momento, o sistema antigo era considerado como bom por fornecer todas estas informações de modo satisfatório, mas aos poucos deixou de atender as principais necessidades da empresa essenciais ao cumprimento das leis. Sendo assim, os gestores não podiam mais adiar esta decisão. Iniciou-se todo o processo, desde a procura pelo sistema ideal, até seu atual funcionamento.

A escolha do software se deu levando em consideração a atividade da empresa. Não poderia ser qualquer sistema, pois, por se tratar de uma operadora de planos de saúde regulamentada pela ANS, ele deveria estar sempre sendo atualizado e configurado às necessidades da empresa.

Foi preciso muito esforço de toda a equipe para se adaptar ao "inovador" sistema. Houveram várias reuniões para demonstração de seu funcionamento e as principais características e atividades do novo sistema. Mas na prática, tudo era muito diferente, 0 que exigiu trabalho árduo de todos os funcionários para que tudo desse certo. E apesar das diversas reuniões inicias os profissionais não tiveram tempo de passar por nenhum treinamento. À medida que iam alimentando o sistema, aproveitavam para conhecer as telas e os comandos. Havia uma base de teste, mas tudo era feito em tempo real. A empresa fornecedora do software é de outro Estado, o que dificultava um pouco mais a 
assistência e o suporte aos usuários do sistema, mesmo tendo um assistente presente acompanhando todo processo pessoalmente. Colaboradores relataram que era muito difícil entender todos os processos em tão pouco tempo, o que exigia cada vez mais empenho individual, e muitas vezes eram necessárias jornadas extras de trabalho. Durante este tempo, todos ficaram muito sobrecarregados, porém vestiram a camisa da empresa e fizeram um ótimo trabalho.

No início, também foi constatada uma forte resistência de alguns colaboradores diante da migração, o que é natural diante de uma mudança tão brusca, pois a maioria precisou sair da zona de conforto para se adaptar as novas rotinas. Além disso, foi destacado que o tempo de implantação era muito curto, visto que, além de todo o transtorno causado pela migração, os profissionais não podiam deixar de desempenhar suas atividades rotineiras, já que todos os procedimentos tinham tempo determinado para serem entregues. Ressaltaram também a importância do treinamento antes da implantação, o que não foi feito. Mesmo assim, se dedicaram muito, pois tinham consciência da importância desta mudança e que ela traria muitos benefícios para eles e para a empresa.

Todo o processo demorou cerca de dois anos, desde a escolha do sistema até a finalização da implantação. A análise mostra que mesmo depois de quase tudo estar funcionando, os colaboradores ainda não sabem usar na totalidade todos os recursos oferecidos pelo sistema e ainda o mesmo não consegue atender todas as necessidades dos setores. Está em constante adaptação, porém, o antigo sistema já foi inutilizado, servindo apenas para consultas a históricos muito antigos.

\subsection{ASPECTOS POSITIVOS OBSERVADOS NO PROCESSO DE IMPLANTAÇÃO DO SISTEMA}

$\mathrm{Na}$ entrevista foi destacado pelos usuários que um dos principais benefícios da implantação de um novo sistema é o fato de ele ser um sistema que trabalha por integração entre os módulos e com isso proporciona mais agilidade, rapidez no desempenho das tarefas, diminuiu os riscos de erros, por eliminar muito trabalho manual e também a redução dos custos.

Outo destaque é o fato de que antigamente era permitido ao setor de contabilidade promover alterações nos lançamentos efetuados pelo setor financeiro. Isso agora não é mais possível o que desperta nos usuários o cuidado dobrado no momento de lançar as informações no sistema e evitar o retrabalho.

Chama a atenção também a questão do número de telas. No antigo sistema, para fazer um único lançamento era necessário passar por vários caminhos, sendo necessário, às vezes, ter que abrir duas ou mais telas, limitando o uso dos demais colaboradores. Isso fazia com que ocorressem congestionamentos no sistema e impossibilitava que alguns usuários fizessem seu trabalho em tempo hábil. Agora o número de telas é compatível 
com o número de usuários, visto que dentro de uma única tela é possível abrir várias abas para desenvolver os procedimentos.

O suporte também melhorou muito. Existe um grupo de pessoas conectadas em tempo integral por um comunicador online e eles estão sempre prontos para esclarecer as dúvidas, prestar a devida assistência no momento em que for preciso. Quando os problemas não são sanados imediatamente através do comunicador, existe outro programa com a finalidade de abrir "chamados", os quais são gerados em forma de protocolos e são constantemente acompanhados até serem respondidos e finalizados, o que só ocorre quando o problema é definitivamente resolvido. Antes já existia a solicitação de assistência em forma de "chamados", porém, o retorno era muito demorado e atrasava o desempenho dos trabalhos.

Sendo assim, de um modo geral o novo sistema trouxe muitos benefícios para a empresa, otimizou o tempo dos funcionários, que agora executam as tarefas de forma mais precisa e ágil, além de diminuir os índices de erros.

\section{I ASPECTOS NEGATIVOS OBSERVADOS NO PROCESSO DE IMPLANTAÇÃO DO SISTEMA}

Uma das partes mais complexas da implantação foi a adaptação dos colaboradores às mudanças. No início houve uma grande resistência, visto que os processos eram feitos da mesma maneira há aproximadamente 20 anos. Era necessária a mudança imediata para um novo padrão já que o antigo sistema não era capaz de atender as exigências atuais, e isso causou grande transtorno a princípio.

Houve muita sobrecarga de trabalho, exigindo grande empenho dos colaboradores e até uma jornada extra de trabalho até que todos os processos fossem entendidos pelos usuários, houve grandes momentos de tensão e aconteciam muitos erros. Depois da finalização do processo de implantação, o sistema ainda precisa ser monitorado e algumas mudanças são feitas constantemente. Nada ainda aplicado totalmente, pois os colaboradores aprendem coisas novas todos os dias e o sistema é obrigado a atender uma nova exigência a cada dia. É um constante aprendizado.

Muitas informações foram importadas do antigo sistema, como por exemplo, cadastro, de beneficiários, históricos financeiros, cadastro de fornecedores, contas bancárias, dentre outras. E por se tratar de sistemas diferentes foi preciso muitas adaptações. Ainda hoje são encontrados muito erros que precisam ser concertados diariamente.

O novo sistema também foi considerado, a princípio, um pouco complexo. No momento da transação haviam muitos campos abertos, já que eram necessários alguns lançamentos manuais para alimentá-lo. Com isso, era muito fácil o manuseio errôneo do sistema, o que era muito difícil reverter e atrasava muito o processo. O tempo previsto 
para a implantação era de um ano, mas foi estendido por dois anos, devido à demora na adaptação.

De acordo com a pesquisa, os pontos negativos pesaram muito no processo de implantação, que foi considerado como "cansativo e complicado", pois causou grande transtorno e desgastou muito os colaboradores. Os benefícios vão surgindo aos poucos. Os funcionários já conseguem manusear o novo sistema com mais confiança e alguns conseguiram voltar a sua jornada normal de trabalho. No fim das contas foi um alto investimento e seu retorno é bastante lento.

\section{I CONSIDERAÇÕES FINAIS}

Esta pesquisa teve como objetivo mostrar como foi feito a implantação de um novo sistema em uma operadora de planos de saúde e apresentar os pontos positivos e negativos de toda a transição. Esta mudança foi necessária para cumprir as exigências de órgãos fiscalizadores e para melhorar o desempenho das atividades dos colaboradores.

A metodologia utilizada se enquadra como uma pesquisa descritiva, no que se refere aos objetivos, qualitativa no que tange a abordagem e estudo de caso quanto aos procedimentos. O levantamento das informações foi feito através de uma entrevista com os colaboradores da empresa e ocorreu em meados de Junho deste ano.

Percebe-se que através da implantação de um novo sistema foi possível reduzir alguns custos, agilizar procedimentos, otimizar o tempo da equipe, diminuir riscos de erros, entre outros. Porém com todo o desgaste que a transação proporcionou, baseado no estudo de caso, foi verificado que se espera que com a alteração no sistema os

verdadeiros benefícios apareçam a longo prazo, melhorando ainda mais o desempenho das atividades.

A integração do departamento contábil com as demais áreas da empresa, tais como, autorização, faturamento, cadastro, auditoria, comercial, entre outros ainda é um objetivo a ser alcançado. Essa integração de todos os departamentos é essencial para o contexto gerencial da entidade de forma que as informações produzidas auxiliam diretamente na tomada de decisão. Sendo assim, quanto maior for a integração de um sistema operacional dentro da empresa maior será o controle das movimentações e informações fidedignas para ajudar na tomada de decisões, o que neste caso ainda levará um pouco de tempo para acontecer.

Em virtude do prazo de adaptação e utilização do novo sistema identificou-se melhorias no processo, mas foi preciso muito empenho dos colaboradores para finalizar a transação. Ressalta-se que não é suficiente a simples compra e implantação do sistema, pois durante todo esse período observou-se impactos positivos e negativos que merecem ser considerados como importantes na imersão de um novo sistema de informação em 
uma entidade.

Como pontos negativos destacam-se o desgaste do pessoal envolvido, a demora na adaptação, os erros que aparecem ainda hoje, mesmo após a finalização da implantação, além do fato de que os usuários ainda não consegue dominar todas as ferramentas oferecidas por ele, e ainda o sistema não atende totalmente a demanda dos usuários, sendo necessárias várias atualizações e a criação de novos módulos para auxiliar no desempenho das atividades.

Dentre os pontos positivos, destaca-se que financeiro e contabilidade compartilham de um sistema que fala a mesma linguagem para a importação dos dados. $O$ número de telas é proporcional ao número de usuários. Além disso, o suporte técnico também melhorou muito por ser feito diretamente através de comunicadores on line ou ainda pode ser feito por chamados que são abertos e atendidos em tempo hábil. $E$ ainda há uma promessa do pessoal responsável pelo sistema de que um dia a integração de todos os setores será feita em tempo real.

Assim, foi constatado neste estudo a importância de se ter um bom sistema operacional em uma organização o que é essencial para se manter competitivo em um mercado cada vez mais exigente. Mas é importante salientar que para viver uma transação desse porte é necessário um planejamento bem estruturado. Talvez pesquisas com outras entidades que conheçam o produto e já passaram por uma transação desse tipo podem impactar em menores riscos e maiores facilidades durante implementação do sistema.

\section{REFERÊNCIAS}

ANDRADE, Maria Margarida de. Introdução a metodologia do trabalho científico: elaboração de trabalhos na graduação. 10. ed. São Paulo: Atlas, 2010.

APPOLINÁRIO, Fabio. Metodologia científica. São Paulo: Cengage Learning, 2016.

BARKER, Richard. Introdução à contabilidade. São Paulo: Saraiva, 2013.

BATISTA, Emerson de Oliveira. Sistemas de Informação: o uso consciente da tecnologia para o gerenciamento. 2. ed. São Paulo: Saraiva ,2012.

CRUZ, Ana Paula Alves; DACOL, Silvana; REBELO, Luiza Maria Bessa. O impacto do sistema financeiro corporativo na administração do negócio e sua relação com a gestão estratégica: um estudo de caso numa empresa de componentes para o segmento eletro-eletrônico do Pólo Industrial de Manaus (PIM). In: Anais do Congresso Brasileiro de Custos-ABC. 2008.

FAVERO, Hamilton Luiz et al. Contabilidade: teoria e prática. 7. ed. São Paulo: Atlas, 2011.

FERNANDES, Edison Carlos; NETO, Arthur Ridolfo. Contabilidade aplicada ao direito. São Paulo: Saraiva, 2014. 
GONÇALVES, Rosana C.M Grillo; RICCIO, Edson Luiz. Sistemas de informação: ênfase em controladoria e contabilidade. São Paulo: Atlas, 2009.

GONÇALVES, Eugênio Celso: BAPTISTA, Antônio Eustáquio. Contabilidade geral. 7. ed. São Paulo, Atlas, 2011.

IUDÍCIBUS, Sergio de. Teoria da contabilidade. 11. ed. São Paulo: Atlas, 2015.

IUDICIBUS, Sergio de; MARION, José Carlos; FARIA, Ana Cristina de. Introdução á teoria da contabilidade: para graduação de acordo com os CPCs e as normas internacionais de contabilidade. 6. ed, São Paulo: Atlas, 2017.

CORNACHIONE JR, Edgard. Informática aplicada às áreas de contabilidade, administração e economia. 4. ed. São Paulo: Atlas, 2012.

LAURINDO, Fernando José Barbin et al. O papel da tecnologia da informação (TI) na estratégia das organizações. Gestão \& Produção, v. 8, n. 2, p. 160-179, 2001.

LAKATOS, Eva Maria; MARCONI, Maria de Andrade. Fundamentos de Metodologia Científica. São Paulo: Atlas, 2017.

MARION, José Carlos. Contabilidade básica. 10 ed. São Paulo: Atlas, 2009.

NIYAMA, Jorge Katsumi. Teoria Avançada da Contabilidade. São Paulo: Editora Atlas, 2014.

OLIVEIRA, Edson. Contabilidade Digital. São Paulo: Atlas, 2014.

PADOVEZE, Clóvis Luís. Sistemas de informações contábeis: fundamentos e análise. São Paulo: Atlas, 2000.

PELEIAS, Ivam Ricardo et al. Pesquisa sobre a percepçao dos usuários dos módulos contábil e fiscal de um sistema ERP para o sector de transporte rodoviário de cargas e passageiros. JISTEM-Journal of Information Systems and Technology Management, v. 6, n. 2, p. 247-270, 2009.

SANTOS, José Luiz dos; SCHMIDT, Paulo; MACHADO, Nilson Perinazzo. Fundamentos da teoria da contabilidade: coleção resumos de contabilidade. São Paulo: Atlas, 2005.

SEBRAE. Como implantar um sistema efetivo de escuta do cliente? 0 caso da CDS informática. Disponível em: http://www.sebrae.com.br/Sebrae/Portal\%20Sebrae/UFs/ES/ Anexos/ES_cds_16_pdf.pdf. Acesso em 22 mar. 2018.

TAVARES, Adilson de Lima. Implantação de ERP e seus impactos na geração da informação contábil um estudo de caso em uma empresa de distribuição de energia elétrica. In: Anais do Congresso USP de Controladoria e Contabilidade. 2005.

WICKERT, Ilse Maria Beuren. Como elaborar trabalhos monográficos em contabilidade: Teoria e prática. $3^{a}$ edição. São Paulo: Atlas, 2013. 


\section{PREVISÃO DE INADIMPLÊNCIA UTILIZANDO REGRESSÃO LOGÍSTICA APLICADO A TOMADORES DE CRÉDITO DE UMA INSTITUIÇÃO FINANCEIRA}

Data de aceite: $24 / 07 / 2020$

Jediel Ferreira dos Reis Fundação Universidade Federal de Rondônia UNIR, Rondônia, ORCID: https://orcid.org/00000002-4777-4535

Vania Corrêa Mota Fundação Universidade Federal de Rondônia UNIR, Departamento de Matemática e Estatística

- DAME, Rondônia,

ORCID: https://orcid.org/0000-0001-8838-718X

Irene Yoko Taguchi Sakuno

Fundação Universidade Federal de Rondônia UNIR, Departamento de Matemática e Estatística

- DAME, Rondônia,

ORCID: https://orcid.org/0000-0001-7532-6521

Josivan Ribeiro Justino

Fundação Universidade Federal de Rondônia UNIR, Departamento de Matemática e Estatística

- DAME, Rondônia,

ORCID: https: //orcid.org/0000-0002-4705-9312

RESUMO: Este trabalho teve como objetivo realizar um estudo da inadimplência dos tomadores de crédito de uma instituição financeira da cidade de Ji-Paraná/RO por meio da regressão logística, de modo que fosse possível gerar um modelo capaz de prever a probabilidade de um tomador de crédito como potencial inadimplente ou adimplente com base em seu perfil cadastrado no sistema da instituição financeira. A amostra é composta por 959 tomadores de crédito de uma instituição financeira da cidade de Ji-Paraná/ RO referente ao período de 2013 a 2019. As variáveis independentes foram categorizadas. O método de regressão logística multivariável foi utilizado para a escolha e estimação das variáveis. Um modelo de regressão logística foi criado, composto por seis variáveis: sexo, quantidade de parcelas, taxa de juros, tem seguro prestamista, tem algum avalista e nível de educação. Com base na modelagem, a variável que mais contribui para inadimplência foi "sim para seguro prestamista". Os resultados indicam que o modelo proposto foi significativo para a classificação dos tomadores de crédito com $81,9 \%$ de acerto. $O$ modelo pode ser recomendado para uso de previsão em instituições financeiras, como apoio à gestão, mitigando assim o risco de se fornecer crédito a um tomador que tenha certa probabilidade de se tornar inadimplente.

PALAVRAS-CHAVE: Concessão de Crédito, Gestão de risco, Modelo Logístico, Níveis de Inadimplência. 


\section{OF A FINANCIAL INSTITUTION}

ABSTRACT: This study aimed to conduct a study of default by borrowers of a financial institution in the city of Ji-Paraná / RO by logistic regression, so that it is possible to generate a model to predict the probability of a credit borrower as a potential defaulter or a defaulter based on his profile registered in the financial institution's system. The sample consists of 959 borrowers from a financial institution in the city of Ji-Paraná / RO for the period from 2013 to 2019. The independent variables were categorized. The multivariable logistic regression method was used to choose and estimate the variables. A logistic regression model was created, composed of six variables: sex, number of installments, interest rate, has credit insurance, has a guarantor and education level. Based on the modeling, the variable that contributed most to default was "yes to credit life insurance". The results indicate that the proposed model was significant for the classification of borrowers with $81.9 \%$ accuracy. The model can be recommended for use in forecasting in financial institutions, as a support to management, thus mitigating the risk of providing credit to a borrower who is likely to become in default.

KEYWORDS: Granting of Credit. Risk management, Logistic Model, Default Levels.

\section{I INTRODUÇÃO}

Antigamente era comum chegar a determinados comércios e encontrar cadernos de anotações onde os comerciantes tinham anotados as dívidas a serem pagas por seus clientes, era uma relação de confiança entre comerciante e comprador. Contudo, com o avanço da tecnologia, esse sistema foi crescendo e se modificando, chegando a ser atualmente uma estrutura que influencia diretamente a economia de um país (PERERA et al. 2012).

De maneira sucinta o termo crédito, está relacionado à confiança, significa dispor a um tomador recursos financeiros para fazer frente a despesas, dívidas ou aquisição de algum bem, com a expectativa de que a parcela volte a sua posse depois de decorrido um tempo estipulado (SCHRICKEL, 1994). Nos últimos anos o crédito tem alcançado níveis consideráveis, sendo utilizado como instrumento para geração de riqueza e negócios (PERERA et al. 2012). Segundo estatísticas do Banco Central do Brasil (BACEN), o saldo das operações de crédito do Sistema Financeiro Nacional (SFN) alcançou R $\$ 3,3$ trilhões em março de 2019 (BRASIL, 2019). Este número expressivo está relacionado, dentre outros fatores ao incentivo ao crédito propiciado pela estabilização do real e a alta concorrência bancária, como se pode observar das informações constantes do Relatório de Economia Bancária, a seguir citada: 
Em termos prospectivos, de acordo com a Pesquisa Trimestral sobre Condições de Crédito (PTC), realizada em março de 2019, as expectativas das instituições financeiras são de crescimento nos saldos de crédito para 2019: de 5,5\% para grandes empresas; 5,0\% para micro, pequenas e médias empresas; $8,0 \%$ para consumo de pessoas físicas; e 5,0\% para crédito habitacional. As projeções do BCB para 2019 são de crescimento de $7,2 \%$ do saldo total de crédito, com aumentos de $12,5 \%$ e 0,8\% dos saldos de crédito com recursos livres e direcionados, respectivamente. Para pessoas físicas e jurídicas, projeta-se expansão anual do estoque de crédito de 9,7\% e 4,1\%, respectivamente. Para pessoas físicas e jurídicas, projeta-se expansão anual do estoque de crédito de 9,7\% e 4,1\%, respectivamente (BRASIL, 2018, p. 9).

Em decorrência do aumento exponencial da concessão de crédito e os altos níveis de inadimplência, a gestão de riscos passou a ser peça fundamental nas instituições financeiras, de maneira que qualquer erro relacionado à concessão de uma operação de crédito pode gerar perdas do ganho obtido em dezenas de outras operações bem sucedidas. (STEINER et al. 1999). A partir de fevereiro de 2017 o BACEN normatizou a gestão de riscos de forma integrada, chamando a atenção, por exemplo, para o risco de uma análise de crédito deficitária o que poderá acarretar possível inadimplência e consequentemente falta de liquidez de uma instituição financeira (BRASIL, 2017).

Em 2018 o número de brasileiros incluídos no SPC chegou a 63,6 milhões de indivíduos, segundo o órgão este número é explicado pela baixa na atividade econômica aliada a falta de confiança do empresariado em voltar a investir ou contratar, além disso, o alto índice de desemprego associado ao cenário político conturbado explica a renda insuficiente de consumidores para arcar com compromissos financeiros.

Com base nos argumentos apresentados, fica evidente a necessidade de se implementar políticas e critérios mais robustos para avaliação e concessão de crédito. As instituições devem avaliar todas as informações possíveis a fim de conceder incentivos financeiros para o cliente que apresentar maior chance de pagamento. A análise subjetiva que leva em consideração o julgamento humano tem sido substituída por análises racionais, tendo como âncora as técnicas estatísticas que tem apresentado grande eficiência no meio financeiro.

Deste modo, o presente trabalho tem como objetivo classificar o possível tomador como potencial inadimplente ou adimplente, identificando características que possam predizer esta classificação com um determinado nível de confiança utilizando a regressão logística.

\section{I MATERIAL E MÉTODOS}

O universo da pesquisa é composto por uma população de 959 dados cadastrais de pessoas físicas e/ou jurídicas que foram tomadores de crédito durante o período de 2013 a 2019 em uma Instituição Financeira da cidade de Ji-Paraná/RO. Com base nos dados 
coletados foi possível a elaboração de uma análise exploratória por meio de gráficos e tabelas, buscando visualizar o comportamento geral deste (Mota et al. 2008).

As variáveis ao perfil sociodemográfico utilizadas retrata o perfil social do tomador de crédito, sendo elas: faixa etária, sexo, naturalidade, escolaridade, capacidade civil, estado civil, profissão. Já as variáveis referentes ao perfil socioeconômico descrevem as características financeiras do tomador, sendo elas: vínculo empregatício, cargo exercido, salário mensal, números de dependentes, renda mensal, tipo de operação, cadastro positivo.

As variáveis independentes foram categorizadas. O método de regressão logística multivariável foi utilizado para a escolha e estimação das variáveis (Hair et al. 2009; Corrar, Paulo e Dias Filho, 2017). Assim, como resultado para a análise da presente pesquisa a variável resposta é categórica binária, onde $Y=0$ será atribuída para clientes adimplentes e $Y=1$ para clientes inadimplentes. Para esboçar as probabilidades utilizouse a seguinte expressão (Hair et al. 2009; Corrar, Paulo e Dias Filho, 2017):

$$
P(\text { evento })=\frac{1}{1+\mathrm{e}^{-\left(\mathrm{b}_{0}+\mathrm{b}_{1} \mathrm{x}_{1 \mathrm{i}}+\mathrm{b}_{2} \mathrm{x}_{2 \mathrm{i}}+\ldots+\mathrm{b}_{\mathrm{k}} \mathrm{x}_{\mathrm{ki}}\right)}}
$$

Para avaliar o desempenho do modelo utilizou as seguintes medidas:

i) Log Likelihood representado pela expressão -2LL que é o resultado da multiplicação do logaritmo natural do Likelihood value por -2. Segundo Hair et al (2009), um ajuste perfeito tem um valor de -2LL igual a 0 . Significa que quanto menor o índice de $\log$ Likelihood, melhor o poder de predição do modelo.

ii) $R^{2}$ Logit que expressa a variação percentual entre o Likelihood Value e considera apenas a constante e o Likelihood que incorpora as variáveis explicativas, conforme se verifica a seguir:

$$
\mathrm{R}^{2} \text { logit }=\left[\frac{\text { 2LLnulo }-(-2 \text { LLmodelo })}{-2 \text { LLnulo }}\right]
$$

Para Hair et al. (2009), assim como na contraparte da regressão múltipla o valor $\mathrm{R}^{2}$ logit varia de 0 a 1 . A medida que o ajuste do modelo proposto aumenta, o -2LL diminui. Sendo assim considerando um ajuste ideal, o $R^{2}$ logit deverá ser 1 . E o $R^{2}$ de Cox e Snell (1968) que se apresenta do mesmo modo do anterior, com valores maiores indicando melhor ajuste do modelo. 
iii) O teste de Hosmer e Lemeshow (HOSMER, HOSMER E LEMESHOW, 1980).

iv) A estatística de Wald que Segundo Mezzomo (2009) e Corrar, Paulo e Dias Filho (2017), pode ser calculado conforme demonstrado a seguir:

$$
W_{i}=\frac{\beta_{i}}{\operatorname{E.P.}\left(\beta_{i}\right)}
$$

em que $\beta_{i}$ é o coeficiente de uma variável independente incluída no modelo;

E. P. é o erro-padrão (standard error). O software utilizado para as análises foi o SPSS®STATISTICS 22.

\section{I RESULTADOS E DISCUSSÃO}

O produto crédito é o maior produto do portfólio de um banco comercial, administrar os recursos de terceiros é sem dúvida um negócio lucrativo. Dentre as mais diversas funções de uma instituição financeira está o provimento de meios para rentabilizar os recursos oriundos de aplicações de clientes superavitários, pagando-lhes uma taxa negociada de acordo com o tempo mínimo de carência escolhido e que faça referência a algum benchmark (taxa Selic, DI etc.). O fornecimento de crédito ao cliente deficitário é realizado em troca de uma taxa de juros pactuada; tal negociação têm apresentado altos níveis de lucratividade.

$\mathrm{Na}$ figura 1 pode ser observado o percentual da população de tomadores de crédito de uma instituição financeira da cidade de Ji-Paraná, por gênero e por vínculo empregatício num período de 2013 a 2019. É possível verificar que o gênero que se destaca é o masculino com um percentual de $82 \%$.
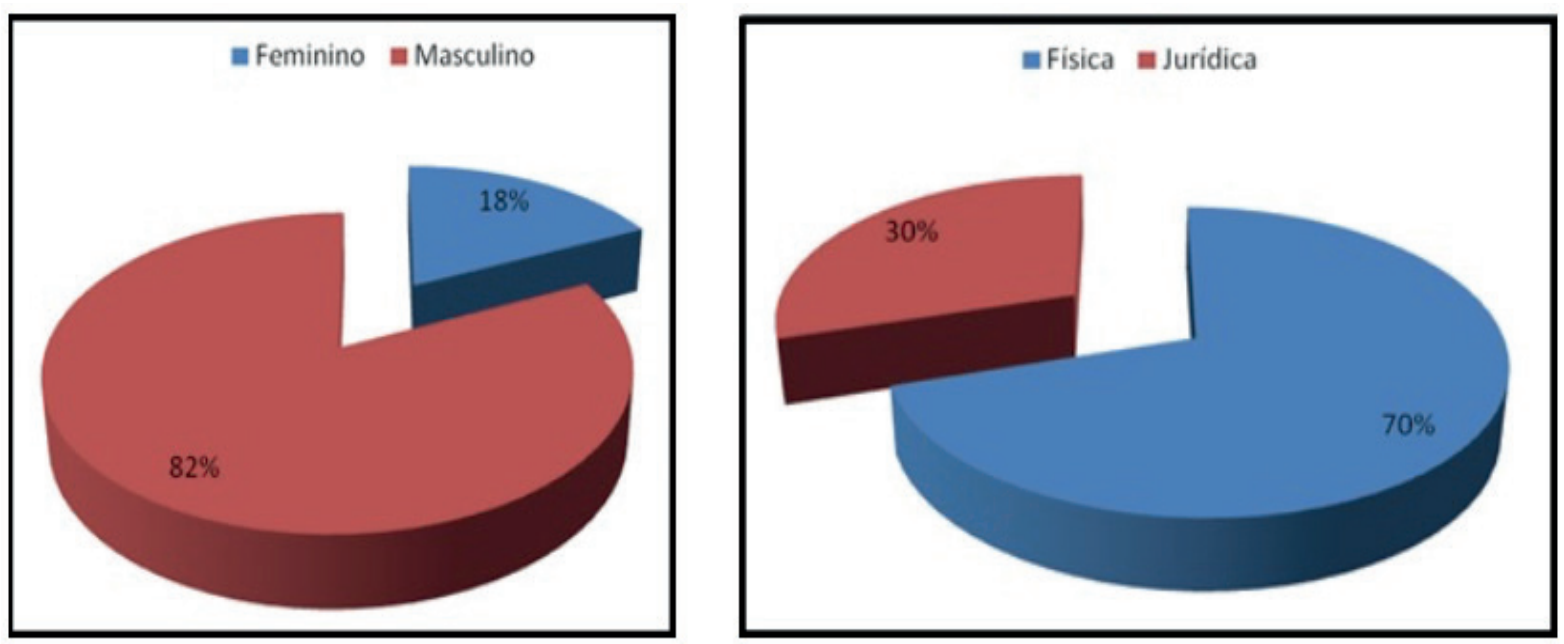

FIGURA 1: Percentual dos tomadores de créditos por gênero e por vínculo empregatício (2013 a 2019$).$ 
Percebe-se que dentre os tomadores de crédito analisados ganham destaque a população que se caracteriza por ser pessoa física, pois esse grupo tem como percentual $70 \%$ do total de tomadores de crédito.

$\mathrm{Na}$ figura 2, tem-se o percentual dos tomadores de crédito em relação ao seu estado civil e por vínculo empregatício. Onde se observa que grande parte da população são pessoas com o estado civil solteiro, com um percentual de $48 \%$, seguido dos casados, com um percentual de $36 \%$. Considerando os dados obtidos, fica evidente que não existe no banco de dados dessa pesquisa pessoas com o status separado. Já o percentual por vínculo empregatício, tem-se que a maior parte da população de tomadores de crédito de Ji-Paraná são empregados (públicos ou privados), com um percentual de $64 \%$, seguidos dos autônomos, com percentual de $11 \%$.
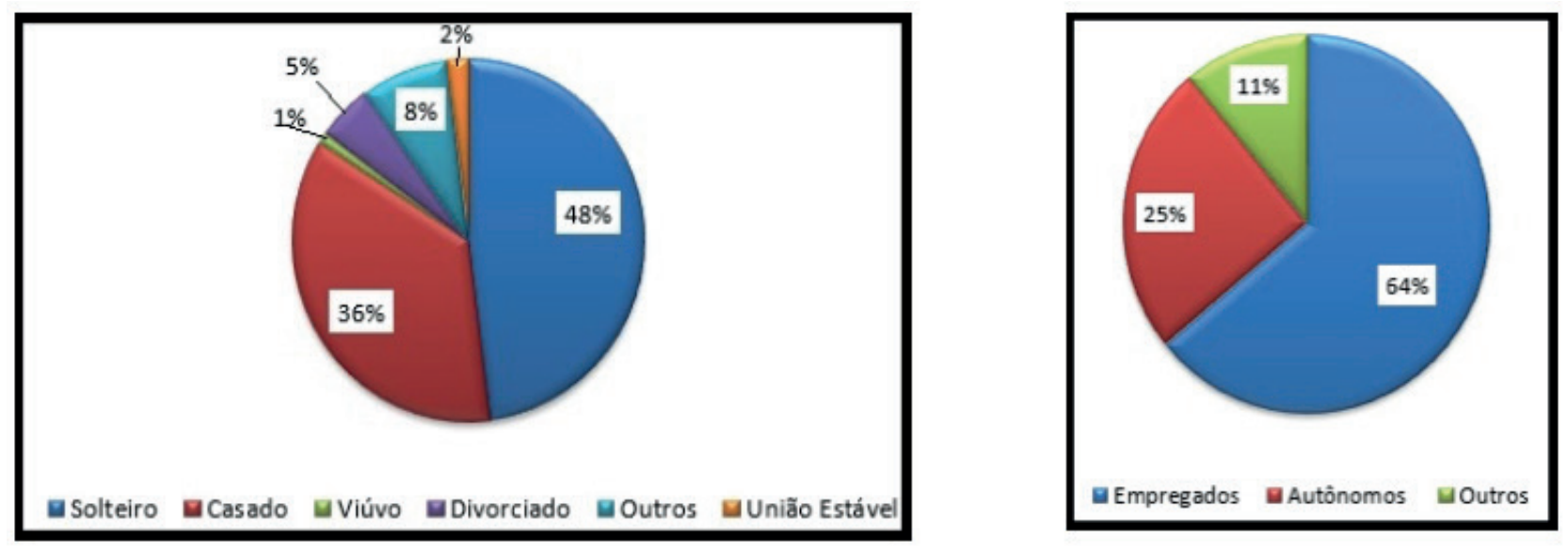

FIGURA 2: Percentual dos tomadores de créditos em relação ao seu estado civil e por vínculo empregatício (2013 a 2019).

Quando tomamos como referência instituições financeiras, o crédito está relacionado a colocar determinada quantia a disposição de um tomador mediante o compromisso de pagamento em data futura (BRITO; ASSAF NETO, 2005). Para Silva (2006) a confiança é um fator necessário, mas não pode ser tomado como suficiente para a decisão de concessão de crédito. Sendo assim fornecer crédito sem garantias de recebimento é um fator de risco que deve ser observado.

Segundo Brito e Assaf Neto (2005), o risco de crédito é divido em três partes: risco de inadimplência (default), risco de exposição e risco de recuperação. No que se refere à inadimplência podemos considerar a probabilidade de o tomador entrar em default, o risco de exposição está relacionado à incerteza do valor futuro da operação e o risco de recuperação se refere à incerteza quanto ao valor que poderá ser recuperado no caso do tomador entrar em default.

$\mathrm{Na}$ tabela 1 pode-se observar a classificação inicial dos casos com a observação da situação de inadimplência e adimplência dos tomadores de crédito de acordo com seu 


\begin{tabular}{l|l|c|c|c}
\hline \multirow{2}{*}{ Observado } & \multicolumn{3}{c}{ Previsto } \\
\cline { 3 - 5 } \multicolumn{2}{c|}{} & \multicolumn{2}{|c}{ Situação } & $\begin{array}{c}\text { Porcentagem } \\
\text { correta (\%) }\end{array}$ \\
\hline \multirow{2}{*}{ Situação } & Adimplente & Inadimplente \\
\cline { 2 - 5 } & Inadimplente & 362 & 0 & 100,0 \\
\hline \multicolumn{2}{c}{ Porcentagem global (\%) } & & 0 & 0,0 \\
\hline
\end{tabular}

TABELA 1: Classificação inicial dos dados

É possível perceber que inicialmente, o modelo estatístico demonstrado na tabela 1, apresenta uma classificação prévia dos casos sem a utilização das variáveis independentes. Assim, os 597 casos observados como adimplente foram classificados como adimplentes corretamente representando $100 \%$ de acerto. Os 362 casos ressalvados como inadimplente foram classificados incorretamente como adimplentes, constituindo 0,0\% de acerto. $O$ modelo estatístico também exibe o resultado global, no qual o percentual de acerto é de $62,3 \%$. O resultado global é utilizado para comparar o acréscimo de acerto do modelo estatístico após a inclusão das variáveis independentes.

Na tabela 2 pode ser verificada a estatística de Wald reminiscente à significância da variável constante incluída no modelo de regressão. A finalidade da estatística de Wald é de "aferir o grau de significância de cada coeficiente da equação logística, inclusive a constante" (CORRAR; PAULO; FILHO, 2017, p. 296). Para realizar os cálculos da estatística de Wald são utilizados a Eq. 3.

\begin{tabular}{c|c|c|c|c|c|c|c}
\hline & & B & S.E. & Wald & df & Sig. & Exp.(B) \\
\hline Etapa 0 & Constante & $-0,500$ & 0,067 & 56,400 & 1 & 0,000 & 0,606 \\
\hline
\end{tabular}

TABELA 2: Estatística Wald para a constante do modelo de regressão

* B é o coeficiente Beta do modelo; S.E. é o erro padrão; Walt é resultado do teste Walt; df é o grau de liberdade; Sig. é o valor do p-valor para o teste Walt; Exp.(B) é o expoente de Beta (razão de chance); I. C. é o intervalo de confiança.

Assim, tem-se que a estatística de Wald é de 56,400 com significância de 0,000, ou seja, esse resultado mostra que a variável constante do modelo de regressão é significativa (sig. <0,05). Do exposto, conclui-se que a regressão logística é significante e coopera para formular previsões sobre o risco de inadimplência. Posteriormente, têmse os pseudos- $R^{2}$ de Cox \& Snell e de Nagelkerke exibidos na tabela 3, sendo que esses resultados servem para avaliar o desempenho geral do modelo de regressão para que seja possível prever o risco de inadimplência.

A seleção das variáveis foi realizada por meio do método de Backward (FREI, 2018) para definir o modelo final, pois esse método minimiza o número de variáveis e maximiza 
a precisão do modelo. Assim, este método dispôs de 2 etapas e selecionou 6 das 15 variáveis incluídas inicialmente no modelo. Sendo essas variáveis as seguintes: Sexo, Quantidade de parcelas, Taxa de juros, Tem seguro prestamista, Tem algum avalista e Nível de educação.

\begin{tabular}{c|c|c|c}
\hline Etapa & Verossimilhança de log -2 & $R^{2}$ Cox \& Snell & $R^{2}$ Nagelkerke \\
\hline 1 & $747,900^{a}$ & 0,421 & 0,573 \\
\hline
\end{tabular}

TABELA 3: Resumo do modelo de regressão

Os resultados dos pseudos- $R^{2}$ de Cox e Snell "procuram indicar a proporção das variações ocorridas no log da razão de chance que é explicada pelas variações ocorridas nas variáveis independentes" (CORRAR; PAULO; FILHO, 2017, p. 309). Nesse sentido, o resultado de $R^{2}$ Cox \& Snell indica que cerca de $42,1 \%$ das variações ocorridas no log da razão de chance são explicadas pelas variações das variáveis independentes. De igual modo, considerado como uma versão adaptada de Cox \& Snell, o teste de Nagelkerke indica que as variáveis independentes influenciam $57,3 \%$ nas variações do logaritmo da razão de chance. É importante ressalvar que não é usual conferir essas estatísticas isoladamente (FARIAS, 2018).

O indicador Teste de Hosmere Lemeshow é um teste Qui-quadrado que tem a função de verificar a "hipótese de que não há diferenças significantes entre os resultados preditos pelo modelo e os observados" (CORRAR; PAULO; FILHO, 2017, p. 308). Dessa forma, os dados apresentam um Qui-quadrado de 23,027 e um nível de significância de 0,003, como pode observado na tabela 4.

\begin{tabular}{c|c|c|c}
\hline \multirow{2}{*}{ Etapa } & Qui-quadrado & df & Sig. \\
\hline 1 & 23,027 & 8 & 0,003 \\
\hline
\end{tabular}

TABELA 4: Teste de Hosmer e Lemeshow

*df é o grau de liberdade; Sig. é o valor do p-valor para o teste.

Logo, verifica-se que os valores previstos não são significativamente diferentes dos observados, uma vez que, a significância foi maior que 0,05. Assim, fica evidente que existem indícios que demonstram que o modelo de regressão logística pode ser empregado para que se possa aferir a probabilidade de um determinado tomador de crédito se tornar inadimplente em função das variáveis independentes utilizadas.

Em concordância com o teste acima apresentado, temos o teste de Hosmer e Lemeshow em 10 etapas (tabela 5), nas quais não vemos diferenças entre os valores 
observados e esperados, conforme vimos no ajuste global do modelo no teste anterior.

Diante dos testes realizados pelo SSPS, foram gerados os resultados de classificação final dos casos com o uso do modelo de regressão logística, conforme mostra a tabela 6.

O modelo de regressão logística tem percentual de acerto de classificação geral de $81,9 \%$. Levando em consideração o bom ajuste do modelo, há como seguir com a interpretação dos coeficientes, estimando o efeito individual no modelo.

As variáveis com betas significativos para o modelo de previsão de inadimplência, de acordo com a análise realizada foram: Sexo, Quantidade de parcelas, Taxa de juros, Tem seguro prestamista, Tem algum avalista e Nível de educação.

\begin{tabular}{cccccc}
\hline \multirow{2}{*}{ Etapas } & \multicolumn{2}{c}{$\begin{array}{c}\text { Adimplente ou Inadimplente } \\
\text { Adimplente }\end{array}$} & $\begin{array}{c}\text { Adimplente ou Inadimplente } \\
\text { = Inadimplente }\end{array}$ & \multirow{2}{*}{ Total } \\
\cline { 2 - 5 } & Observado & Esperado & Observado & Esperado & \\
\hline 1 & 96 & 95.68 & 0 & 0.32 & 96 \\
2 & 96 & 95.04 & 0 & 0.96 & 96 \\
3 & 88 & 88.86 & 8 & 7.14 & 96 \\
4 & 82 & 80.55 & 14 & 15.45 & 96 \\
5 & 80 & 73.50 & 16 & 22.50 & 96 \\
6 & 46 & 63.23 & 50 & 32.77 & 96 \\
7 & 55 & 48.78 & 41 & 47.22 & 96 \\
8 & 31 & 30.72 & 65 & 65.28 & 96 \\
9 & 21 & 15.90 & 75 & 80.10 & 96 \\
10 & 2 & 4.75 & 93 & 90.25 & 95 \\
\hline
\end{tabular}

TABELA 5: Tabela de contingência para o teste de Hosmer e Lemeshow

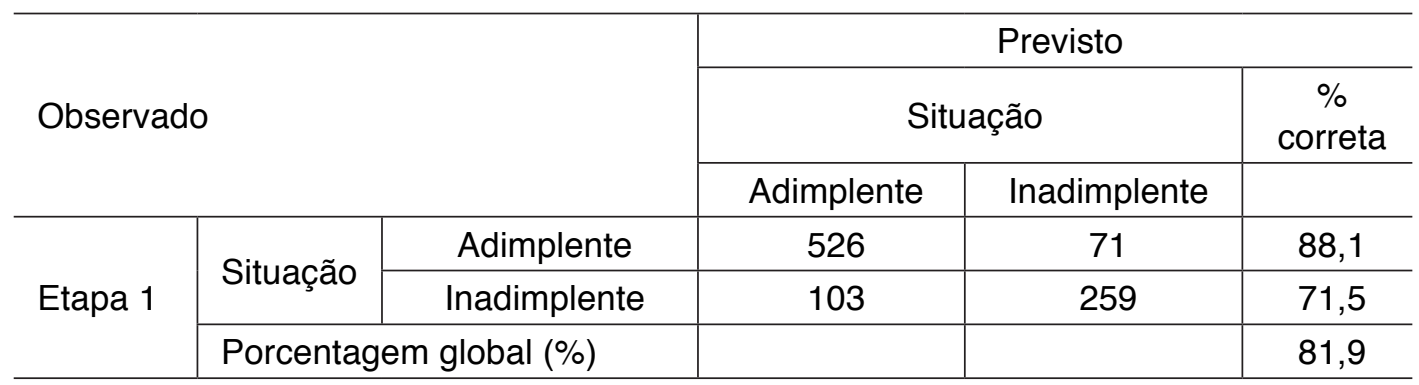

TABELA 6: Classificação final dos casos

Na tabela 7 estão apresentados os coeficientes das variáveis do modelo de regressão logística com seus respectivos resultados dos testes.

As variáveis que se mostraram significativas e que por sua vez contribuíram para a previsão de inadimplência. Usando os coeficientes de regressão da tabela, pode-se prever valores considerando casos individuais ou conjuntos. Vale ressaltar que a probabilidade foi baseada no evento, ou seja, o cliente ser inadimplente.

Iniciando as interpretações dos coeficientes, a variável sexo é significante, como mostrado anteriormente e possui o odds-ratio de 2,07 , ou seja, sendo a relação de 
comparação a última categoria, tem-se a seguinte relação: homens em relação às mulheres, têm 2,07 mais chances de ocorrer o evento, que seria 1, ou seja, serem inadimplentes. Assim, os homens têm $170 \%$ mais chance de serem inadimplentes do que as mulheres. $O$ efeito da chance foi medido por exponencial de beta, que é equivalente a $\mathrm{e}^{\wedge} \beta$. Este valor é expresso em termos de odds-ratio. Além disso, verifica-se que o intervalo de confiança para o $\beta$ da variável sexo, varia entre 1,27 e 3,39, ou seja, não contém o valor 1 , o que corrobora a significância estatística do $\beta$

\begin{tabular}{lcccccccc}
\hline \multicolumn{1}{c}{ Variáveis } & B & S.E. & Wald & df & Sig. & \multicolumn{2}{c}{ Exp.(B) } & \multicolumn{2}{c}{ 95\% I.C. para Exp.(B) } \\
\hline & & & & & & & Inferior & Superior \\
Sexo(masculino) & 0.73 & 0.25 & 8.49 & 1 & 0.00 & 2.07 & 1.27 & 3.39 \\
Quantidade de parcelas & 0.09 & 0.01 & 134.50 & 1 & 0.00 & 1.10 & 1.08 & 1.11 \\
Taxa de juros mensal & 0.62 & 0.14 & 20.31 & 1 & 0.00 & 1.86 & 1.42 & 2.43 \\
Tem seguro prestamista(sim) & 3.88 & 0.56 & 47.39 & 1 & 0.00 & 48.29 & 16.01 & 145.63 \\
Tem algum avalista (sim) & -0.50 & 0.19 & 6.63 & 1 & 0.01 & 0.61 & 0.42 & 0.89 \\
Nível de educação & & & 32.26 & 2 & 0.00 & & & \\
$\begin{array}{l}\text { Nível de educação (Superior } \\
\text { incompleto) }\end{array}$ & -1.25 & 0.22 & 31.42 & 1 & 0.00 & 0.29 & 0.19 & 0.44 \\
$\begin{array}{l}\text { Nível de educação (Superior } \\
\text { completo/ pós graduação) }\end{array}$ & -1.24 & 0.34 & 13.15 & 1 & 0.00 & 0.29 & 0.15 & 0.57 \\
Constante & -6.09 & 0.79 & 59.43 & 1 & 0.00 & 0.00 & & \\
\hline
\end{tabular}

TABELA 7: Variáveis do modelo de regressão logística

* B é o coeficiente Beta do modelo; S.E. é o erro padrão; Walt é resultado do teste Walt; df é o grau de liberdade; Sig. é o valor do p-valor para o teste Walt; Exp.(B) é o expoente de Beta (razão de chance);

I. C. é o intervalo de confiança.

Analisando a quantidade de parcelas do empréstimo, ela também possui significância estatística no teste Wald e possui seu intervalo de confiança entre 1,08 e 1,11. Como ela é uma variável escalar, a interpretação é em relação ao aumento em uma unidade em seu valor, então a chance do evento aumenta em exponencial de beta (odds-ratio). Em termos práticos, aumentando-se uma parcela, o indivíduo tem uma chance de 1,1 de favorecer o evento, ou seja, ser inadimplente. Assim, o aumento no número de parcelas contribui em $10 \%$ a mais na chance de o indivíduo ser inadimplente.

A taxa de juros mensal também possui significância na estatística Wald e seu intervalo de confiança não passa pelo valor 1 (entre 1,42 e 2,43). Analisando sua odds-ratio, temse que: aumentando-se em uma unidade a taxa de juros mensal, a chance do evento de o cliente ser inadimplente aumenta em 1,86, ou seja, juros altos aumentam em $86 \%$ a chance da inadimplência.

Quanto à variável tem seguro prestamista, esta também possui significância estatística no teste Wald e seu intervalo de confiança varia entre 16,01 a 145,63. Se o cliente tem seguro prestamista, em relação aos que não têm, a chance de ele ser inadimplente aumenta em 48,29\%. 
Em relação à variável tem avalista, esta também possui significância estatística no teste Wald e seu intervalo de confiança varia entre 0,42 a 0,89 , porém possui $\beta<0,0$ que significa que essa variável favorece de forma inversamente proporcional o evento (favorece o não evento, que é ser adimplente). No tocante às chances, se o cliente tem avalista, a chance dele ser adimplente varia 0,61, ou seja, clientes que têm avalistas são mais propensos a não serem inadimplentes. Ocorre uma diminuição de $39 \%$ a chance dele ser inadimplente.

Por fim, tem-se a variável nível de educação que está apartada em duas dummies. As duas dummies possuem significância estatística no teste Wald e intervalo de confiança não passando pelo valor 1 (Nível de educação Superior incompleto de 0,19 a 0,44 e Nível de educação Superior completo/pós-graduação de 0,15 a 0,57). Ambas possuem $\beta<0$, ou seja, uma relação inversamente proporcional com o evento.

Clientes que possuem ensino superior incompleto, em relação aos que não informaram o nível educacional, possuem uma chance de 0,29 de serem adimplentes (o $\beta<0$ favoreceu o não evento). Clientes com nível superior apresentam um risco de inadimplência menor de $71 \%$, em relação a pessoas com nível de escolaridade menor.

Clientes que possuem ensino superior completo/pós-graduação, em relação aos que não informaram o nível educacional, também possuem uma chance de 0,29 de serem adimplentes (o $\beta<0$ favoreceu o não evento).

Conforme demonstrado anteriormente foi possível chegar a um modelo capaz de descrever a relação existente entre o fenômeno inadimplência e as variáveis: sexo, quantidade de parcelas, taxa de juros, tem seguro prestamista, tem avalista, e nível de educação, tomando-se então como referência um conjunto de dados históricos pertencentes a uma instituição financeira da cidade de Ji-Paraná/RO.

Nesse sentido, suponha-se que se deseja estimar a probabilidade de inadimplência ou adimplência de um tomador de crédito, levando em consideração que o mesmo seja do sexo masculino, tenha seguro prestamista e tenha sua taxa de juros aumentada em 1 unidade. Assim, com base nos dados da tabela 7 e usando a expressão (1), tem-se a probabilidade 99, 46 \% para um tomador de crédito com este perfil (Figura 3). Agora, suponha-se que o tomador de crédito seja do sexo masculino, e apresente grau de instrução ensino superior completo. Neste caso, a probabilidade com este perfil é de $37,51 \%$.

Nesse caminho, suponha-se que esse tomador de crédito seja do sexo masculino, tenha tido sua taxa de juros mensal aumentada em uma unidade, tenha grau de instrução superior incompleto e tenha avalista a probabilidade é 40,13\%. Agora, suponha que o tomador de crédito seja do sexo masculino, tenha tido sua taxa de juros mensal aumentada em uma unidade, tenha grau de instrução superior incompleto, porém não tenha avalista. Neste caso, a probabilidade para o egresso com este perfil sem avalista, apresenta chance de inadimplência da ordem de 52,49\%. Na figura 3 são apresentadas mais suposições 
para este modelo com suas respectivas probabilidades.

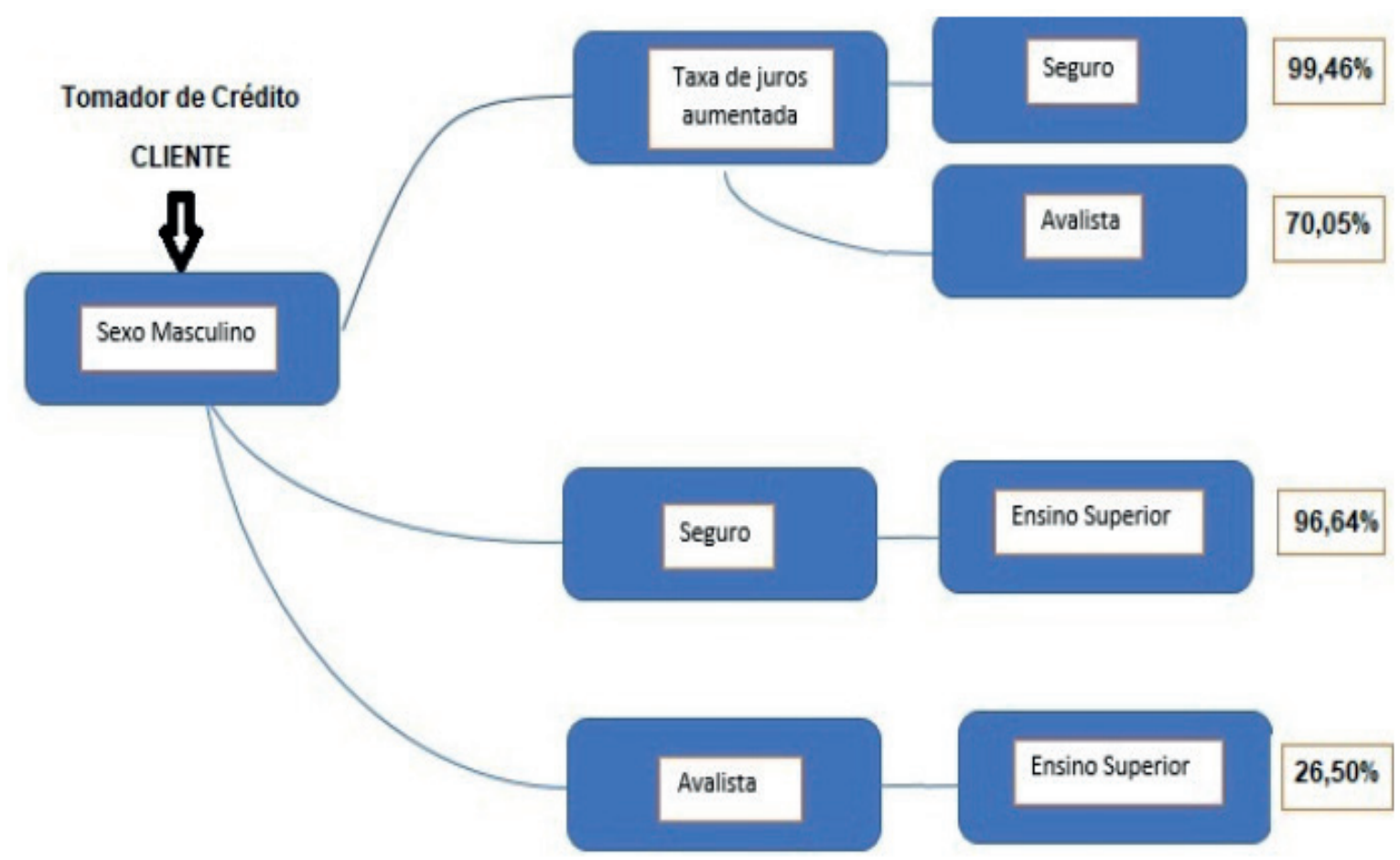

FIGURA 3: Suposições para o modelo de regressão logística elaborado com suas respectivas probabilidades considerando o tomador de crédito do sexo masculino

A utilização de modelos de previsão de inadimplência tem sido crucial na tomada de decisão das instituições financeiras, uma vez que a classificação de risco do cliente implica no nível de provisionamento contábil, impactando diretamente no seu resultado.

Com base nos resultados foi possível identificar padrões que poderão ser utilizados pela instituição financeira para alocar um cliente em grupo específico e assim embasar a tomada de decisão no momento da concessão de crédito. A instituição financeira pode utilizar o modelo logístico para auxiliar na aplicação de incentivos a promitentes com maior probabilidade de pagamento.

\section{I CONCLUSÕES}

A variável que mais contribui para inadimplência foi "sim para seguro prestamista". Os resultados indicam que o modelo proposto foi significativo para a classificação dos tomadores de crédito com $81,9 \%$ de acerto. O modelo pode ser recomendado para uso de previsão em instituições financeiras, como apoio à gestão, mitigando assim o risco de se fornecer crédito a um tomador que tenha certa probabilidade de se tornar inadimplente. 


\section{I AGRADECIMENTOS}

Os autores agradem ao Grupo de Pesquisa em Modelos Matemáticos, Estatísticos e Fuzzy - MEMF.

\section{REFERÊNCIAS}

BRASIL. (2019) Estatísticas monetárias e de crédito: Operações de crédito. Disponível em: <https://www. bcb.gov.br/estatisticas/estatisticasmonetariascredito> Acesso em: 28 jun. 2019.

BRASIL. Relatório de Economia Bancária. Banco Central do Brasil, 2018. Disponível em: https://www.bcb. gov.br/content/publicacoes/relatorioeconomiabancaria/reb_2018.pdf. Acesso em: 28 jun. 2019.

BRASIL. Resolução n 4.557/2017. Banco Central do Brasil. Edital de Consulta Pública nº 57/2017, 2017. Disponível em: https://www.bcb.gov.br/pre/normativos/busca/downloadNormativo.asp?arquivo=/Lists/ Normativos/Attachments/50344/Res_4557_v1_O.pdf. Acesso em: 28 jun. 2019.

BRITO, G. A. S; NETO, A. A. Modelo de classificação de risco de crédito de grandes empresas. In: $5^{\circ}$ CONGRESSO USP DE CONTROLADORIA E CONTABILIDADE, São Paulo, 2005. Anais [...]. Disponível em: https://congressousp.fipecafi.org/anais/artigos52005/383.pdf. Acesso em: 11 jan. 2020.

CAOUETTE, J. B. et al. Gestão do risco de crédito: o grande desafio dos mercados financeiros globais. 2. ed. Rio de Janeiro: Qualitymark, SERASA, 2009. 624 p.

CORRAR, L. J; PAULO, E; FILHO, M. Análise multivariada: para os cursos de administração, ciências contábeis e economia. FIPECAFI - Fundação Instituto de Pesquisas Contábeis, Atuariais e Financeira. 1. ed. São Paulo: Atlas, 2017. 568 p.

COX, D. R.; SNELL, E. J. A general definition of residuals (With discussion). J.R. Stat. Soc. B. London, v.30, n.2, p.248-275, 1968.

FARIAS, P. B. Uso da regressão logística para um estudo de reincidência criminal no sistema penitenciário mediciense. 2018. $52 \mathrm{f}$. Trabalho de Conclusão de Curso (Graduação em Estatística) - Universidade Federal de Rondônia. Ji-Paraná/RO, Brasil. Disponível em: http://www.ri.unir.br/jspui/ handle/123456789/2348. Acesso em: 15 jun. 2019.

FREI, F. Introdução à Inferência Estatística aplicações em saúde e biologia, 1. Ed., Rio de Janeiro: Interciência, 2018, 564 p.

HAIR, J. F., et al. Análise Multivariada de Dados. 5. ed. Porto Alegre: Bookman, 2005. 593 p.

HAIR, J. F; et al. Análise multivariada de Dados. 6.ed. Porto Alegre: Bookman, 2009. 688 p.

HOSMER, D.W., HOSMER, T. AND LEMESHOW, S. A Goodness-of-Fit Tests for the Multiple Logistic Regression Model. Communications in Statistics, Filadélfia, v. 9, n. 10, p. 1043-1069. 1980.

MEZZOMO, M. Estudo da mortalidade Infantil - um estudo de regressão logística múltipla. 2009. 60 f. Trabalho de Conclusão de Especialização (Especialização em Estatística e Modelagem Quantitativa) - Centro de Ciências Naturais e Exatas Universidade Federal de Santa Maria. Santa Maria, RS, Brasil. Disponível em: https://repositorio.ufsm.br/bitstream/handle/1/2992/Mezzomo _ Meire.pdf?sequence=1\&isAllowed=y. Acesso em: 8 nov. 2019.

MOTA, V. C., LIMA, R.R. DE, ALVES, M. DE C., OLIVEIRA, M.S. DE, CARVALHO, L.G. de Dependência temporal da precipitação pluvial e da temperatura do ar em Juiz de Fora, MG, por meio de análises geoestatísticas. Revista Brasileira de Agrometeorologia, v. 16, n.3, p. 249-258, dez. 2008. 
PERERA, L. C. J; et al. Concessão e Análise de Crédito para Pequenas e Médias Empresas: Estudo de Caso em uma Empresa do Setor de Pescados. In: IX SIMPÓSIO DE EXCELÊNCIA EM GESTÃO E TECNOLOGIA, 2012, Anais [...]. Disponível em: https://www.aedb.br/seget/arquivos/artigos12/31516307.pdf. Acesso em: 10 jan. 2020.

SCHRICKEL, K. W. Análise de crédito: concessão e gerência de empréstimos. 1. ed., São Paulo: Atlas, 1994. $321 \mathrm{p}$.

SILVA, J. P. Gestão e Análise de Risco de Crédito. 4. ed. São Paulo: Atlas, 2006. 423 p.

STEINER, M. T. A. et al. Sistemas especialistas probabilísticos e redes neurais na análise do crédito bancário. Revista de Administração, São Paulo, v. 34, n. 3, p. 56-67, jul./Set. 1999. 
CLEVERSON FLÔR DA ROSA: Professor adjunto da Universidade Tecnológica Federal do Paraná (UTFPR). Doutorado em Administração pela Universidade Federal do Paraná UFPR - Curitiba (2017). Mestrado em Administração pela Universidade Federal do Paraná UFPR Curitiba (2009). Pós-Graduação (Lato Sensu) em Marketing, Gestão de Pessoas e Estratégia Empresarial pela Universidade Estadual do Norte do Paraná - UENP (2005). Graduação em Administração pela Universidade Estadual do Norte do Paraná - UENP (2000) e Graduação em Tecnologia de Desenvolvimento de Sistema de Informação pela Universidade Tecnológica Federal do Paraná UTFPR (2008). Trabalha com os temas: Empreendedorismo, Gestão da Inovação, Competitividade e Desenvolvimento Regional.

JOÃO DALLAMUTA: Professor assistente da Universidade Tecnológica Federal do Paraná (UTFPR). Graduação em Engenharia de Telecomunicações pela UFPR. MBA em Gestão pela Business School. Mestre pela UEL. Doutorando em Gestão de Programas Espaciais pelo Instituto Nacional de Pesquisas Espaciais (INPE). Trabalha com os temas: Inteligência de Mercado, Engenharia Econômica, Gestão de Tecnologia, Planejamento Estratégico.

LUIZ CÉSAR DE OLIVEIRA: Professor adjunto da Universidade Tecnológica Federal do Paraná (UTFPR)- Campus Cornélio Procópio. Graduação em Economia, Especialista em Economia Empresarial pela UEL e Mestrado em Desenvolvimento Econômico pela UFPR. Doutorado em andamento em Economia, Gestão e Tecnologia pela Universidade de Coimbra - Portugal. Trabalha com os temas: Economia, Gestão e Desenvolvimento Econômico, Empreendedorismo e "Triple Helix". 
ÍNDICE REMISSIVO

A

Adoção 9, 10, 11, 12, 13, 14, 15, 16, 17, 18, 19, 20, 21, 55

Amostra 4, 6, 10, 11, 12, 14, 15, 16, 17, 20, 21, 32, 51, 61

Análise Bibliométrica 1, 4, 8

C

Cálculos 3, 46, 67

Câmbio 46

Capes 1, 2, 4, 5, 6, 7

Ciências Sociais 27, 32

Contador 25, 26, 27, 28, 29, 34, 37

Continentais 9, 10,11, 14, 15, 17, 19, 20, 21

Contratos 44

D

Dados 1, 2, 4, 6, 7, 15, 32, 45, 50, 51, 52, 53, 54, 55, 59, 63, 66, 67, 68, 71, 73

Disciplinas 24, 28, 31, 33, 34, 35, 36, 37

E

Empresas 2, 3, 4, 6, 7, 8, 9, 10, 11, 12, 14, 15, 16, 17, 18, 19, 20, 21, 25, 29, 30, 31, 43, 44, 48, $49,50,52,63,73,74$

Ensino a Distância 24, 25, 27, 28, 31, 33, 35, 38

Ensino Presencial 24, 27, 33, 39

Ensino Superior 24, 25, 27, 36, 41, 71

Europa 9, 11, 14, 19, 21, 26, 46, 47

Exigência 31, 42, 57

$\mathbf{F}$

Finanças 1, 6, 9, 23, 24, 42, 61, 75

Flexibilidade 2

I

IFRS 2, 9, 10, 11, 12, 13, 14, 15, 16, 17, 18, 19, 20, 21, 22, 23

Implantação de Sistema 42

Informatização 43 
Juros $46,61,65,68,69,70,71$

$\mathbf{L}$

Lucro 1, 2, 46, 48

M

Metodologia 4, 8, 9, 10, 11, 15, 21, 28, 30, 32, 41, 42, 58, 59, 60

Moedas 46

0

Operadora $42,44,52,53,54,55,58$

Organização 26, 38, 43, 44, 48, 59

Órgãos Fiscalizadores 42, 44, 54, 58

$\mathbf{P}$

Países Anglo-Saxónicos 9, 18, 20

Pesquisas 1, 4, 5, 7, 8, 46, 59, 73, 75

Planos de Saúde 42, 44, 52, 53, 54, 55, 58

Portal 1, 2, 4, 5, 6, 7, 41, 60

Preço $2,3,10,16,17$

$\mathbf{R}$

Registro Contábil 27

Relevância 6, 9, 10,11,12, 13, 14, 15, 16, 17, 18, 19, 20, 21, 23, 50

Resultados $3,4,8,9,10,11,12,13,14,16,17,18,19,20,21,32,33,37,42,44,53,61,65,67$, $68,69,72$

S

Sociedade $25,36,48$

$\mathbf{T}$

Tecnologia 25, 30, 35, 38, 41, 43, 44, 49, 50, 53, 59, 60, 62, 74, 75

Trabalho 7, 11, 29, 37, 42, 43, 44, 50, 51, 52, 53, 54, 55, 56, 57, 58, 59, 61, 63, 73

V

Valuation 1, 2, 3, 4, 5, 6, 7, 8, 23

Venda 2, 3, 44 
www.atenaeditora.com.br

$\triangle$ contato@atenaeditora.com.br

우 @atenaeditora

ff www.facebook.com/atenaeditora.com.br

\section{Contabilidade e Finanças: Normas Internacionais e Mercado Financeiro}

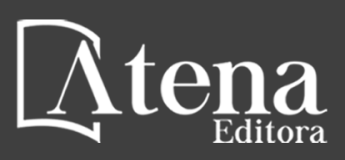

Ano 2020 
www.atenaeditora.com.br

$\triangle$ contato@atenaeditora.com.br

우 @atenaeditora

ff www.facebook.com/atenaeditora.com.br

\section{Contabilidade e Finanças: Normas Internacionais e Mercado Financeiro}

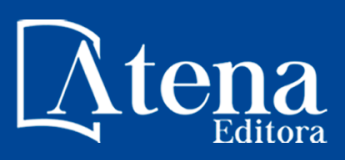

Ano 2020 